$\frac{2}{8} / 2.959820$

Impact of the Renewable Oxygenate Standard for Reformulated Gasoline on Ethanol Demand, Energy Use, and Greenhouse Gas Emissions

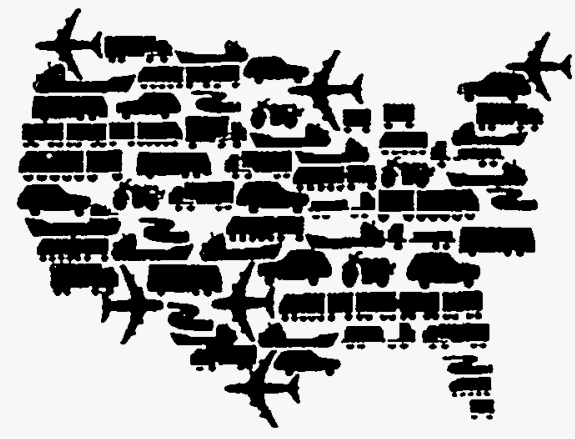

Center for Transportation Research Argonne National Laboratory

Operated by The University of Chicago, under Contract W-31-109-Eng-38, for the

United States Department of Energy 


\section{Argonne National Laboratory}

Argonne National Laboratory, with facilities in the states of Illinois and Idaho, is owned by the United States Government, and operated by the University of Chicago under the provisions of a contract with the Department of Energy.

This technical memo is a product of Argonne's Energy Systems (ES) Division. For information on the division's scientific and engineering activities, contact:

Director, Energy Systems Division

Argonne National Laboratory

Argonne, Illinois 60439-4815

Telephone (708) 252-3724

Presented in this technical memo are preliminary results of ongoing work or work that is more limited in scope and depth than that described in formal reports issued by the ES Division.

Publishing support services were provided by Argonne's Information and Publishing Division.

\section{Disclaimer}

This report was prepared as an account of work sponsored by an agency of the United States Government. Neither the United States Government nor any agency thereof, nor any of their employees, makes any warranty, express or implied, or assumes any legal liability or responsibility for the accuracy, completeness, or usefuiness of any information, apparatus, product, or process disclosed, or represents that its use would not infringe privately owned rights. Reference herein to any specific commercial product, process, or service by trade name, trademark, manufacturer, or otherwise, does not necessarily constitute or imply its endorsement, recommendation, or favoring by the United States Government or any agency thereof. The views and opinions of authors expressed herein do not necessarily state or reflect those of the United States Government or any agency thereof.

Reproduced directly from the best available copy.

Available to DOE and DOE contractors from the Office of Scientific and Technical Information, P.O. Box 62, Oak Ridge, TN 37831; prices available from (615) 576-8401. 


\section{DISCLAIMER}

Portions of this document may be illegible in electronic image products. Images are produced from the best available original document. 


\section{Impact of the Renewable Oxygenate Standard for Reformulated Gasoline on Ethanol Demand, Energy Use, and Greenhouse Gas Emissions}

by Kevin C. Stork and Margaret K. Singh

Center for Transportation Research, Energy Systems Division,

Argonne National Laboratory, 9700 South Cass Avenue, Argonne, Illinois 60439

April 1995

Work sponsored by United States Department of Energy,

Office of Policy, Office of Energy Efficiency and Alternative Fuels Policy

DISTRIBUTION OF THIS DOCUMENT IS UNLIMITED

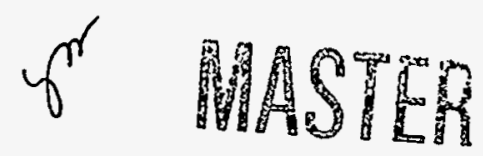


This report is printed on recycled paper. 


\section{CONTENTS}

NOMENCLATURE AND DEFINITIONS OF TERMS $\ldots \ldots \ldots \ldots \ldots \ldots \ldots \ldots$

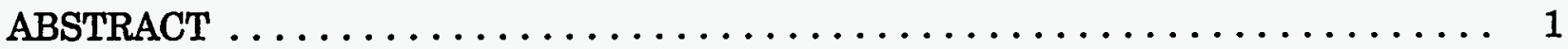

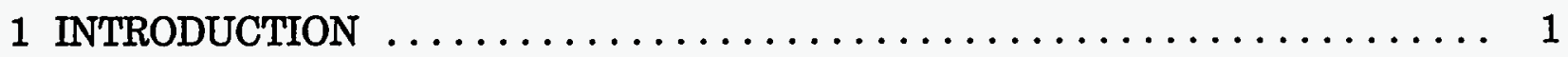

1.1 Purpose and Organization of This Report $\ldots \ldots \ldots \ldots \ldots \ldots \ldots \ldots$

1.2 Reformulated Gasoline Regulations $\ldots \ldots \ldots \ldots \ldots \ldots \ldots \ldots \ldots \ldots \ldots \ldots$

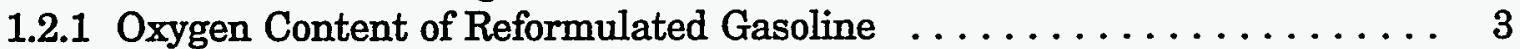

1.2.2 Regional Coverage . . . . . . . . . . . . . . . . . . 4

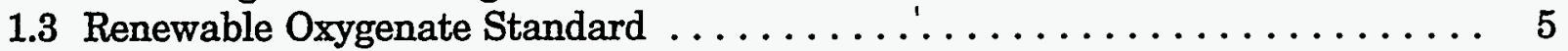

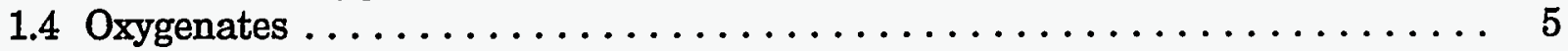

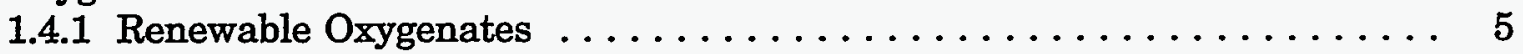

1.4.2 Likely Near-Term Oxygenates . . . . . . . . . . . . . . . . 6

1.4.3 Ethanol Demand . . . . . . . . . . . . . . . . . . . . 7

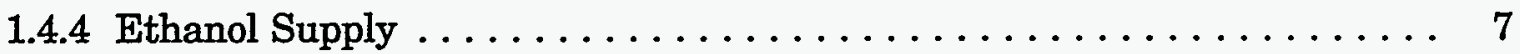

2 RENEWABLE OXYGENATE STANDARD AND THE ETHANOL MARKET . . . . . 9

2.1 Introduction $\ldots \ldots \ldots \ldots \ldots \ldots \ldots \ldots \ldots \ldots \ldots \ldots \ldots \ldots$

2.1.1 Motivation for the Study of Ethanol Supply $\ldots \ldots \ldots \ldots \ldots \ldots \ldots$

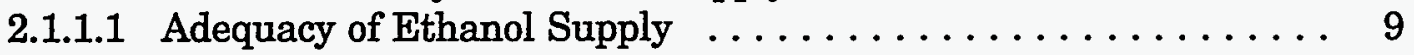

2.1.1.2 Ethanol Logistics System . . . . . . . . . . . . . . . . 10

2.1.1.3 Diversion of Ethanol from Current Use . . . . . . . . . . . 10

2.1.2 Renewable Oxygenate Credit Generation $\ldots \ldots \ldots \ldots \ldots \ldots \ldots \ldots \ldots$

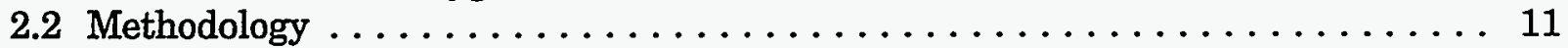

2.2.1 Demand for Reformulated Gasoline . . . . . . . . . . . . . . . . 11

2.2.2 Gasoline and Ethanol Data Sources . . . . . . . . . . . . . . . 12

2.2.3 Use of Ethanol in Nonreformulated Oxygenated Gasoline and Gasohol ................................ 12

2.2.4 Seasonal Oxygenate-Use Case Descriptions . . . . . . . . . . . . . . 13

2.2.4.1 12-Month, Year-Round Case . . . . . . . . . . . . . . . 13

2.2.4.2 6.5-Month, Winter-Only Case . . . . . . . . . . . . . 13

2.2.4.3 3-Month, Front-Loaded Case .................. 14

2.2.5 Time Frames Considered . . . . . . . . . . . . . . . . . . 14

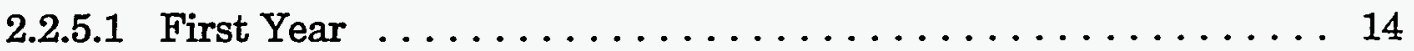

2.2 .5 .2 Near Term . . . . . . . . . . . . . . . . . 15

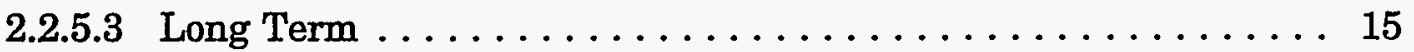

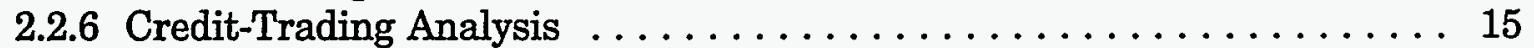

2.3 Results ................................ 16

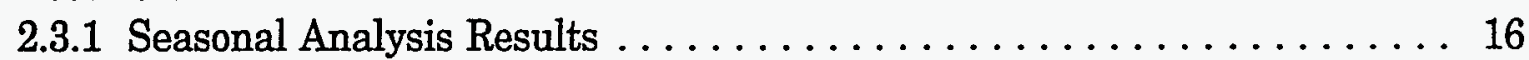

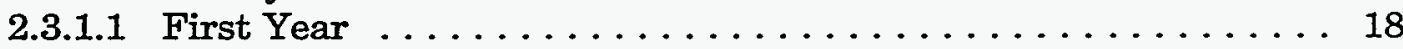

2.3.1.2 Near Term . . . . . . . . . . . . . . . . . . . 19

2.3.1.3 Long Term .......................... 20

2.3.2 Likely Program Operation . . . . . . . . . . . . . . . . 20

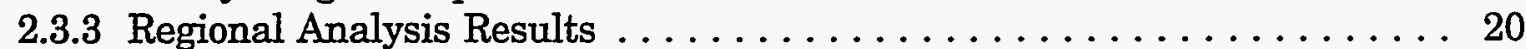

2.3 .4 Conclusions . . . . . . . . . . . . . . . . . . . 23 


\section{CONTENTS (Cont.)}

3 ENERGY USE AND GREENHOUSE GAS EMISSIONS OF

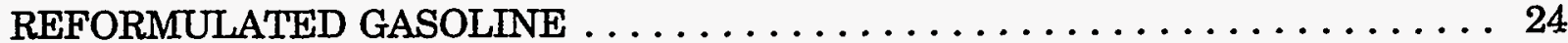

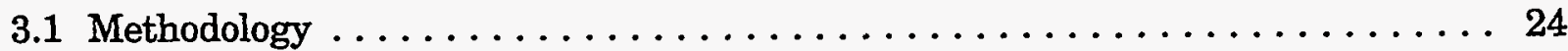

3.1.1 Analytical Framework . . . . . . . . . . . . . . . . . 24

3.1.2 Refinery Modeling . .......................... 24

3.1.3 Greenhouse Gas Emissions Modeling . ............... 28

3.1.4 Normalization of Reformulated Gasolines to Deliver

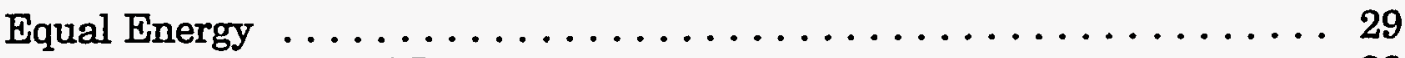

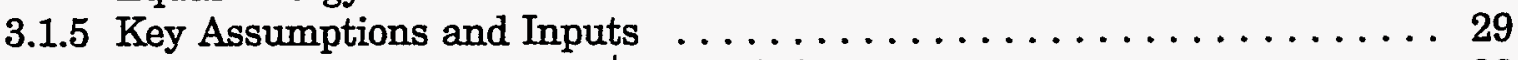

3.2 Volume of RFG Required to Deliver Equal Energy . . . . . . . . . . . 29

3.2.1 Reformulated Gasoline with $2.1 \mathrm{wt} \%$ Oxygen $\ldots \ldots \ldots \ldots \ldots \ldots 29$

3.2.2 Reformulated Gasoline with 2.7 wt\% Oxygen $\ldots \ldots \ldots \ldots \ldots \ldots . \ldots 33$

3.3 Feedstock Requirements: Crude Oil Content . . . . . . . . . . . . 33

3.4 Process Energy Requirements . . . . . . . . . . . . . . . . . 38

3.4.1 Energy and Crude Oil Required to Produce Hydrocarbons . . . . . . . . 38

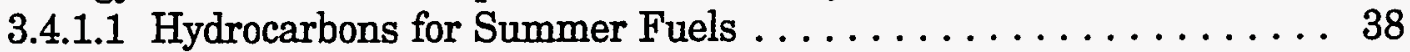

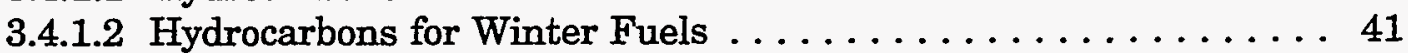

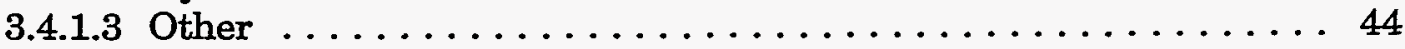

3.4.2 Energy and Crude Oil Required to Produce MTBE . . . . . . . . . 44

3.4.3 Energy and Crude Oil Required to Produce Ethanol ............ 44

3.4.4 Energy and Crude Oil Required to Produce ETBE . . . . . . . . . . 46

3.4.5 Energy and Crude Oil Required to Produce Finished Fuels . . . . . . . . 48

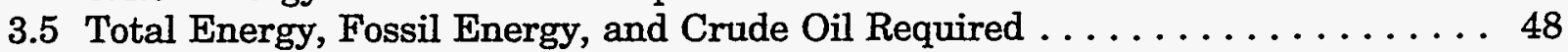

3.6 Greenhouse Gas Emissions of Reformulated Gasoline ............... 49

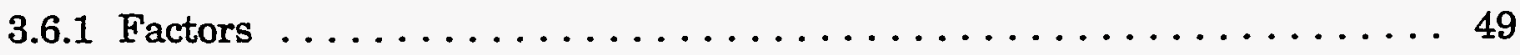

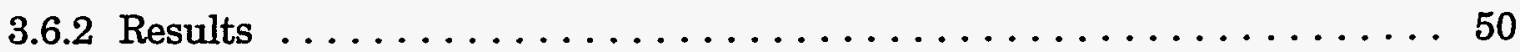

3.7 Most Likely Results $\ldots \ldots \ldots \ldots \ldots \ldots \ldots \ldots \ldots \ldots \ldots \ldots \ldots \ldots \ldots \ldots \ldots$

4 ALTERNATIVE ESTIMATES OF THE IMPACTS OF USING REFORMULATED GASOLINE WITH ETHANOL ON ENERGY USE AND GREENHOUSE GAS EMISSIONS $\ldots \ldots \ldots \ldots \ldots \ldots \ldots \ldots \ldots$

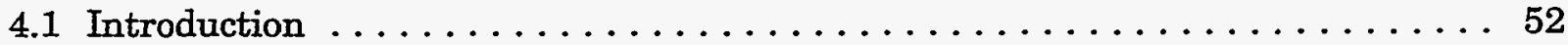

4.2 Delucchi's Estimates of Energy and Crude Oil Required to

Produce Ethanol ........................... 52

4.3 USDA Estimates of Energy and Crude Oil Required to

Produce Ethanol . ............................ 54

4.4 Ho's Estimates of Energy and Crude Oil Required to

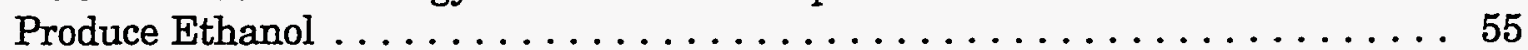

4.5 Greenhouse Gas Emissions Associated with the Use of Ethanol . . . . . . . 56

4.6 Total Energy and Crude Oil Requirements and Greenhouse Gas

Emissions of Reformulated Gasoline Based on Alternative Estimates

of Energy and Crude Oil Required to Produce Ethanol ............. 56

5 PROGRAMWIDE ENERGY USE AND GREENHOUSE GAS EMISSION

EFFECTS OF THE RENEWABLE OXYGENATE STANDARD . . . . . . . . 60 


\section{CONTENTS (Cont.)}

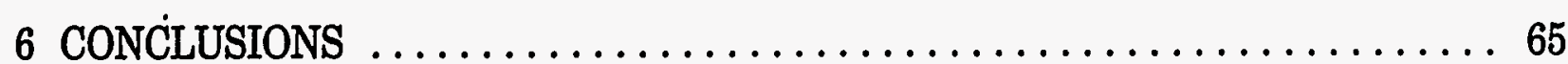

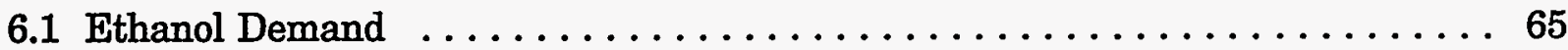

6.2 Energy Use and Greenhouse Gas Emissions
of Reformulated Gasoline $\ldots \ldots \ldots \ldots \ldots \ldots \ldots \ldots \ldots \ldots \ldots \ldots$

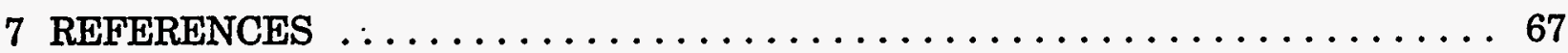

APPENDIX A: Changes Relative to Earlier Argonne Analyses

of Reformulated Gasoline and the Renewable

Oxygenate Standard $\ldots \ldots \ldots \ldots \ldots \ldots \ldots \ldots \ldots \ldots \ldots 69 . \ldots \ldots$

APPENDIX B: Spreadsheet Output on Reformulated Gasoline/

Ethanol Demand .......................... 73

APPENDIX C: Summer Reformulated Gasoline Model Runs ............. 87

APPENDIX D: Winter Reformulated Gasoline Model Runs . ........... 93

APPENDIX E: Cost of Production Estimate for MTBE $\ldots \ldots \ldots \ldots \ldots \ldots \ldots$

APPENDIX F: Ethanol Weighting for Programwide Analysis . ............ 103

APPENDIX G: Delucchi's Base-Case Estimates of Greenhouse Gas

Emissions of Alternative Fuels and Summary Reports

Estimating Energy to Produce Ethanol $\ldots \ldots \ldots \ldots \ldots \ldots \ldots . \ldots 7$

APPENDIX H: Energy and Greenhouse Gas Results for Reformulated

Gasolines on the Basis of the USDA's and Ho's

Estimates of Energy Required to Produce Ethanol .......... 113

\section{TABLES}

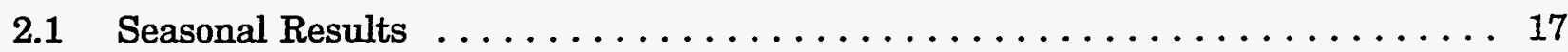

2.2 Maximum Generation of Credits $\ldots \ldots \ldots \ldots \ldots \ldots \ldots \ldots \ldots \ldots \ldots \ldots \ldots \ldots$

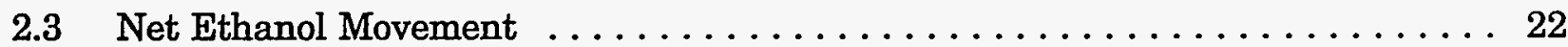

3.1 Characteristics of Selected Summer RFGs Used in PADD II $\ldots \ldots \ldots \ldots \ldots 27$

3.2 Characteristics of Selected Winter RFGs $\ldots \ldots \ldots \ldots \ldots \ldots \ldots \ldots \ldots$ 


\section{TABLES (Cont.)}

3.3 Fuel Volume and Energy Content of RFG with 2.1 wt\% Oxygen and CG

Based on Delucchi's Estimates of Energy and Crude Oil Required to

Produce Ethanol . . . . . . . . . . . . . . . . . . . . . . . 30

3.4 Oxygen and Oxygenate Content of RFG $\ldots \ldots \ldots \ldots \ldots \ldots \ldots \ldots \ldots \ldots \ldots \ldots$

3.5 Energy Densities of Oxygenates and Hydrocarbons $\ldots \ldots \ldots \ldots \ldots \ldots$

3.6 Fuel Volume and Energy Content of RFG with 2.7 wt\% Oxygen and CG

Based on Delucchi's Estimates of Energy and Crude Oil Required to

Produce Ethanol . . . . . . . . . . . . . . . . . . . . . . . 34

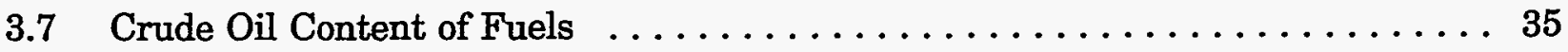

3.8 Refinery Raw Materials and Products for Gasoline Used in PADD II

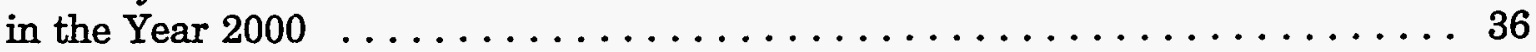

3.9 Plant Fuel Burned and Fuels Purchased to Produce HCs:

Summer Gasolines . . . . . . . . . . . . . . . . . . . . 40

3.10 Plant Fuel Burned and Fuels Purchased to Produce HCs:

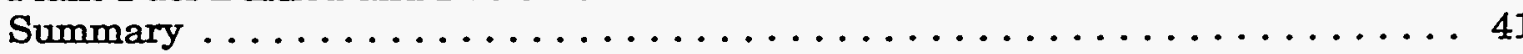

3.11 Plant Fuel Burned and Fuels Purchased to Produce HCs:

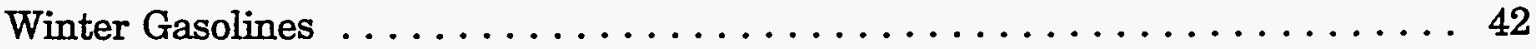

3.12 MTBE Production from Field Butanes: Capacity of 500,000 Metric

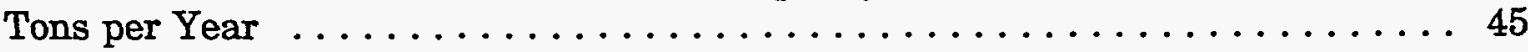

3.13 Weighted Btu Requirements for Ether Production ............... 46

3.14 Delucchi's Base-Case Estimate of Energy and Crude Oil

Required to Produce Ethanol $\ldots \ldots \ldots \ldots \ldots \ldots \ldots \ldots \ldots \ldots$

3.15 ETBE Production Adapted from MTBE Production $\ldots \ldots \ldots \ldots \ldots \ldots \ldots$

3.16 Energy Content and $\mathrm{CO}_{2}$-Equivalent Emissions of Summer and

Winter RFGs Based on Delucchi's Estimate of Energy and Crude Oil

Required to Produce Ethanol: Values Relative to Summer

RFG with MTBE $\ldots \ldots \ldots \ldots \ldots \ldots \ldots \ldots \ldots \ldots \ldots \ldots \ldots \ldots$

$3.17 \mathrm{CO}_{2}$-Equivalent Emissions of RFG Components $\ldots \ldots \ldots \ldots \ldots \ldots \ldots \ldots$

4.1 Alternative Estimates of Energy and Crude Oil Required to

Produce Ethanol ...................................... 53 


\section{TABLES (Cont.)}

4.2 Various Estimates of $\mathrm{CO}_{2}$-Equivalent Emissions of

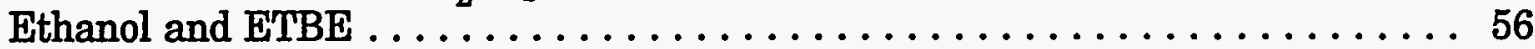

4.3 Energy Content and $\mathrm{CO}_{2}$-Equivalent Emissions of Summer and Winter RFGs Based on Alternative Estimates of Energy and Crude Oil Required to Produce Ethanol: Absolute Values ............ 57

4.4 Energy Content and $\mathrm{CO}_{2}$-Equivalent Emissions of Summer and Winter RFGs Based on Alternative Estimates of Energy and Crude Oil Required to Produce Ethanol: Values Relative to Summer RFG with MTBE $\ldots \ldots \ldots \ldots \ldots \ldots \ldots \ldots \ldots \ldots$

5.1 Volumes of Fuels Used for Programwide Impact Analysis . . . . . . . . . 61

5.2 Programwide Impacts of the ROS in the Near Term: Absolute Values . . . . . . 62

5.3 Programwide Impacts of the ROS in the Near Term: Values

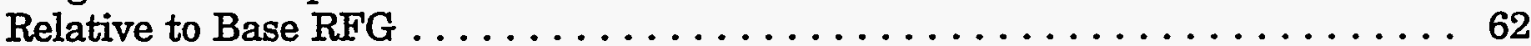

5.4 Programwide Impacts of the ROS in the Long Term: Absolute Values . . . . . . 62

5.5 Programwide Impacts of the ROS in the Long Term: Values

Relative to Base $\mathrm{RFG} . \ldots \ldots \ldots \ldots \ldots \ldots \ldots \ldots \ldots \ldots \ldots \ldots \ldots \ldots \ldots \ldots \ldots$

C.1 Refining Raw Material and Product Rate - MBPCD III C -

Summer 1995/2000 F2 - SF and 4/92 CF Case Results, NPC 1991-92

Study of U.S. Refining Industry . . . . . . . . . . . . . . . . . 89

C.2 Energy Balance Impacts of Ethanol at Constant $\triangle \mathrm{VOC}$ - PADD II

Summer 2000 Cases S13H vs S6[1] NPC 1991-93 Study of

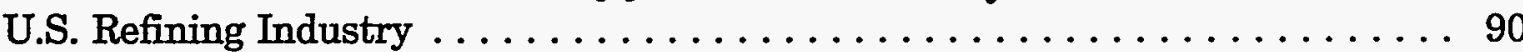

C.3 Run Basis and Reformulated Gasoline Pool Properties IIIC - Summer 2000 F2 - 4/92 CF Case Results NPC 1991-92 Study of

U.S. Refining Industry $\ldots \ldots \ldots \ldots \ldots \ldots \ldots \ldots \ldots \ldots \ldots$

C.4 Refining Raw Material and Product Rates - MBPCD IIIC - Summer 2000 F2 - 4/92 CF Case Results, NPC 1991-92 Study of

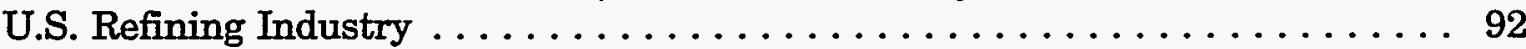

D.1 Energy Balance Impacts of Reformulated Gasoline PADD II Winter 2000 Case Q9W Versus Case Q6W [1] API Study

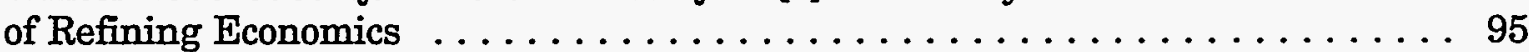

D.2 PADD III Phase II Winter Gasoline Blendstocks $\ldots \ldots \ldots \ldots \ldots \ldots \ldots . . \ldots 6$ 


\section{TABLES (Cont.)}

D.3 PADD III Phase II Raw Material Inputs $\ldots \ldots \ldots \ldots \ldots \ldots \ldots \ldots . . . .97$

D.4 PADD III Phase II Outputs $\ldots \ldots \ldots \ldots \ldots \ldots \ldots \ldots \ldots \ldots \ldots \ldots . \ldots . \ldots . \ldots$

G.1 Results: Fuel Cycle $\mathrm{CO}_{2}$-Equivalent Emissions, by Fuel and Stage $\ldots \ldots \ldots 109$

G.2 Estimates of Energy Used to Grow Corn and Produce Ethanol . . . . . . . 110

H.1 Fuel Volume and Energy Content for RFG with 2.1 wt\% Oxygen:

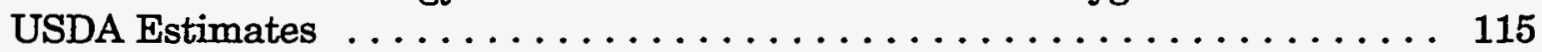

H.2 Fuel Volume and Energy Content for RFG with 2.7 wt\% Oxygen:

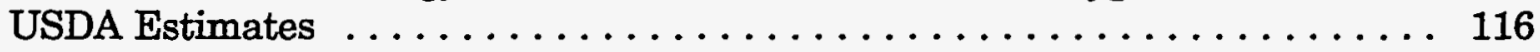

H.3 Fuel Volume and Energy Content for RFG with 2.1 wt\% Oxygen: Ho Estimates .......................... 117

H.4 Fuel Volume and Energy Content for RFG with 2.7 wt\% Oxygen:

Ho Estimates . . . . . . . . . . . . . . . . . . . . . . . . . . . 118

\section{FIGURE}

3.1 Overall Framework Employed in Analysis of Energy and Oil Requirements for RFG Production 


\section{NOMENCLATURE AND DEFINITIONS OF TERMS}

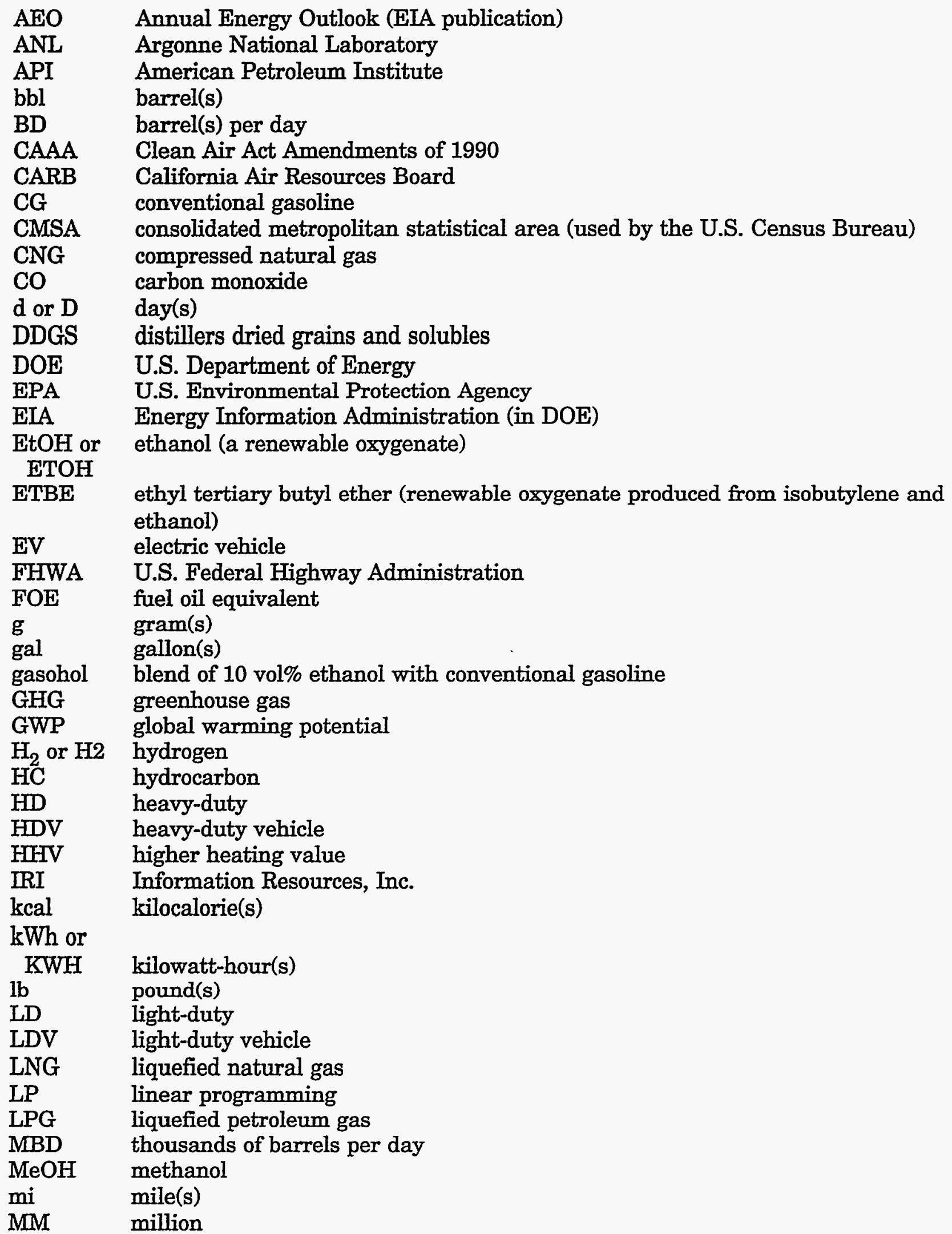




\begin{tabular}{|c|c|}
\hline MMM & billion \\
\hline mo & month(s) \\
\hline MT & metric ton(s) $(2,200 \mathrm{lb})$ \\
\hline MTBE & $\begin{array}{l}\text { methyl tertiary butyl ether (nonrenewable oxygenate produced from isobutylene } \\
\text { and methanol) }\end{array}$ \\
\hline NG & natural gas \\
\hline NGL & natural gas liquid \\
\hline NMHC & nonmethane hydrocarbon \\
\hline $\mathrm{NO}_{\mathrm{x}}$ & nitrogen oxides (ozone precursors) \\
\hline NPC & National Petroleum Council \\
\hline NPRM & Notice of Proposed Rulemaking \\
\hline OG & $\begin{array}{l}\text { oxygenated gasoline (conventional gasoline meeting the federal } O G \text { requirement } \\
\text { for } \mathrm{CO} \text { nonattainment areas) }\end{array}$ \\
\hline OPRG & oxygenate program reformulated gasoline \\
\hline ORNL & Oak Ridge National Laboratory \\
\hline & ozone (a pollutant) \\
\hline PĂDD & Petroleum Administration Defense District \\
\hline ppm & parts per million \\
\hline PSA & Petroleum Supply Annual (EIA publication) \\
\hline psi & pound(s) per square inch \\
\hline $\mathrm{RBOB}$ & reformulated blendstock for oxygenate blending \\
\hline RFG & reformulated gasoline \\
\hline RIA & regulatory impact analysis (EPA publication) \\
\hline ROS & renewable oxygenate standard \\
\hline RVP & $\begin{array}{l}\text { Reid vapor pressure (measure of gasoline volatility defined as the vapor pressure, } \\
\text { in psi, of a } 4: 1 \text { [by volume] air-to-fuel mixture at } 100^{\circ} \mathrm{F} \text { ) }\end{array}$ \\
\hline SEDR & State Energy Data Report (EIA publication) \\
\hline SIP & state implementation plan \\
\hline STEO & Short-Term Energy Outlook (EIA publication) \\
\hline t & metric ton(s) $(2,200 \mathrm{lb})$ \\
\hline TAME & tertiary amyl methyl ether \\
\hline TAP & toxic air pollutant \\
\hline TM & Turner, Mason \& Company \\
\hline ton & short ton(s) $(2,000 \mathrm{lb})$ \\
\hline USDA & U.S. Department of Agriculture \\
\hline VMT & vehicle mile(s) of travel \\
\hline VOC & volatile organic compound \\
\hline vol\% & volume percent \\
\hline wt\% & ight percent \\
\hline
\end{tabular}




\title{
IMPACT OF THE RENEWABLE OXYGENATE STANDARD FOR REFORMULATED GASOLINE ON ETHANOL DEMAND, ENERGY USE, AND GREENHOUSE \\ GAS EMISSIONS
}

by

Kevin C. Stork and Margaret K. Singh

\begin{abstract}
To assure a place for renewable oxygenates in the national reformulated gasoline (RFG) program, the U.S. Environmental Protection Agency has promulgated the renewable oxygenate standard (ROS) for RFG. It is assumed that ethanol derived from corn will be the only broadly available renewable oxygenate during Phase I of the RFG program. This report analyzes the impact that the ROS could have on the supply of ethanol, its transported volume, and its displacement from existing markets. It also considers the energy and crude oil consumption and greenhouse gas (GHG) emissions that could result from the production and use of various RFGs that could meet the ROS requirements. The report concludes that on the basis of current and projected near-term ethanol capacity, if ethanol is the only available renewable oxygenate used to meet the requirements of the ROS, diversion of ethanol from existing use as a fuel is likely to be necessary. Year-round use of ethanol and ETBE would eliminate the need for diversion by reducing winter demand for ethanol. On an RFG-programwide basis, using ethanol and ETBE to satisfy the ROS can be expected to slightly reduce fossil energy use, increase crude oil use, and have essentially no effect on GHG emissions or total energy use relative to using RFG oxygenated only with MTBE.
\end{abstract}

\section{INTRODUCTION}

\subsection{PURPOSE AND ORGANIZATION OF THIS REPORT}

The Clean Air Act Amendments of 1990 (CAAA) call for the establishment of a reformulated gasoline (RFG) program. They require that, beginning on January 1, 1995, RFG replace conventional gasoline (CG) in the nine worst ozone nonattainment areas in the United States with a 1980 population of 250,000 or more (Section 211(k)). Moreover, state implementation plans (SIPs) may also require the use of RFG in other ozone nonattainment areas. The CAAA establish general requirements to be met by RFG with regard to its oxygen, benzene, and heavy metals content and its emissions of nitrogen oxides $\left(\mathrm{NO}_{\mathrm{x}}\right)$. They also require that RFG meet the more stringent of either a formula or a performance standard 
for volatile organic compounds (VOCs) and toxic air pollutants. The performance standards are more stringent for the year 2000 than for 1995.

The U.S. Environmental Protection Agency (EPA) has promulgated regulations to implement the RFG program (Final Rule, December 1993). It proposed a renewable oxygenate standard (ROS) when the RFG regulations were finalized. The ROS was finalized on June 30, 1994. The EPA's regulatory impact analysis (RIA) provides a more complete history and description of the ROS (EPA 1994a).

The ROS has been challenged in a lawsuit brought by the American Petroleum Institute (API) and other parties. In September 1994, the U.S. Circuit Court for the District of Columbia granted the plaintiffs a stay of the ROS until the case is decided. The effects of delays associated with the lawsuit on implementation of the ROS, if it stands, are unknown. ${ }^{1}$

The ROS was adopted to assure a place for renewable oxygenates in the RFG program. The only renewable oxygenate expected to be used in significant volume in the near future is ethanol made from corn. Because oxygenation appears to be the most expensive aspect of Phase 1 RFG production (NPC 1993), any rule affecting the choice of oxygenates could have important consequences for the program as a whole.

This report analyzes the (1) impact that the ROS could have on the supply and transport of ethanol and on its displacement from existing markets; (2) energy and crude oil consumption associated with the production and use of various RFGs that could meet the ROS requirements; and (3) greenhouse gas (GHG) emissions of these RFGs. It also examines how mixed slates of RFGs that could satisfy the ROS would compare with RFGs oxygenated only with methyl tertiary butyl ether (MTBE) in their effect on the RFG program, especially with respect to energy, crude oil, and fossil energy production and use and GHG emissions.

The report updates and consolidates results of earlier Argonne National Laboratory (ANL) analyses conducted for the U.S. Department of Energy (DOE). These include analyses provided to EPA by DOE during deliberations over the ROS (Singh and McNutt 1993; Singh 1994a,b; Stork 1994a,b; others). It extends this earlier work by evaluating the RFG-programlevel impacts of the ROS. Revisions of earlier versions of the analyses are discussed in Appendix A.

Sections 1.2-1.4 of this report briefly review the key elements of the RFG and ROS regulations. The balance of the report is devoted to the effects of the ROS. Section 2

1 The underlying analysis for this report was completed before the lawsuit was filed and so does not reflect uncertainties associated with the lawsuit. If implemented, the ROS will require that $15 \%$ of the required oxygen be derived from renewable oxygenates during the first year and $30 \%$ be derived from them thereafter. Should the ROS eventually take effect, the timetable for implementing it will probably be moved because of the stay. However, the results presented for 1995 should still be generally valid for the first year of the program. This assumption is not a forecast and may prove to be invalid. 
discusses its effects on the demand for and disposition of fuel ethanol. ${ }^{2}$ Section 3 provides base-case estimates of per-gallon energy use (including total energy, fossil energy, and crude oil use) and GHG emissions from RFG. Section 4 contains alternative estimates of energy use and GHG emissions. Finally, Section 5 covers national-level energy use and GHG emissions attributable to RFG.

\subsection{REFORMULATED GASOLINE REGULATIONS}

\subsubsection{Oxygen Content of Reformulated Gasoline}

The CAAA require RFG to contain a minimum of 2.0 weight percent (wt\%) oxygen. The final rule for the RFG program published by EPA allows refiners to meet RFG requirements on either a per-gallon or an average basis. The average standard is slightly more stringent than the per-gallon standard. The averaging standard for oxygen is greater than or equal to $2.1 \mathrm{wt} \%$ oxygen, with not less than $1.5 \mathrm{wt} \%$ in any gallon.

Averaging requires compliance surveys, which may be burdensome enough to cause refiners to meet some standards on a per-gallon basis. The minimum oxygen requirement is particularly easy to meet on a per-gallon basis because the oxygen content can be increased by adding more oxygenate - generally without adversely affecting other parameters for the batch of fuel (e.g., benzene is diluted when MTBE is added to finished gasoline). ${ }^{3}$

Before the final rule for the RFG program was promulgated, the National Petroleum Council (NPC) conducted a study of the capabilities of the domestic refining industry (NPC 1993). It suggested that a compliance margin (i.e., safety margin) would be necessary to assure that refiners attempting to meet the oxygen requirement on a per-gallon basis would actually meet the standard and avoid a penalty. This compliance margin - a $0.1 \mathrm{wt} \%$ oxygen operating margin above the required level - is an estimate of the average margin that the NPC believes refiners will use. Individual refiners could use larger or smaller compliance margins.

Gasoline sold in RFG areas ${ }^{4}$ that are subject to CAAA requirements for oxygenated gasoline (OG) must contain a minimum of $2.7 \mathrm{wt} \%$ oxygen during the winter carbon monoxide

2 Ethanol considered in this report will always be fuel ethanol. Subsequent references to ethanol, with or without that designation, should be considered to refer to fuel ethanol.

3 In some cases, the effect of adding oxygenate is adverse, as it is when VOC emissions are increased because of the addition of ethanol.

4 RFG areas include mandated RFG recipients plus "opt-in areas," a term that is defined in Section 1.2.2. 
(CO) control period and meet criteria as RFG. ${ }^{5}$ No compliance margin has been estimated for such RFG (designated as OPRG, oxygenate program reformulated gasoline).

\subsubsection{Regional Coverage}

In addition to the nine regions in which RFG is required (several cities in the Northeast and Chicago, Houston, Los Angeles, and San Diego), approximately 90 areas classified as serious or moderate ozone nonattainment areas in 1990 can join the RFG program to reduce their pollution. With EPA approval, these areas can join by a process known as "opt in." Opt in becomes effective one year after EPA approval is granted.

By June 1994, some of the 90 areas had joined. However, from July 1994 to the time the ethanol analysis was completed, no more opted in. Moreover, several of the areas that had opted in opted out of the program. These include all Pennsylvania counties outside the Philadelphia metropolitan area (a mandatory area); Jefferson County, New York; the Albany, New York, metropolitan area; the Buffalo, New York, metropolitan area; Hancock and Waldo Counties in Maine; and the June 1994 opt-in areas: Kewaunee, Manitowoc, and Sheboygan Counties in Wisconsin. The EPA has indicated that it will not enforce the RFG rules in areas that have opted out of the RFG program and will initiate a formal rulemaking process to officially allow them to get out of the program. ${ }^{6}$ RFG and oxygenate demand calculations in this report exclude gasoline consumed in the listed opt-out areas.

If population were to remain distributed according to 1991 patterns and if full opt in of the 90 areas were to occur, about 55\% of the U.S. residential population would live in areas receiving RFG. ${ }^{7}$ Full opt in is unlikely, however, not only because some of the areas that had opted in are opting out, but because several potential opt-in areas have indicated they will not participate. For example, Missouri and Georgia SIPs indicate that low-volatility ${ }^{8}$ gasoline rather than RFG will be used in St. Louis and Atlanta. At the current opt-in level, about $30 \%$ of U.S. gasoline is reformulated.

5 In California, because of separate regulation by the California Air Resources Board (CARB), a pergallon maximum oxygen content of $2.0 \mathrm{wt} \%$ is applied to all RFGs in order to avoid increased $\mathrm{NO}_{\mathrm{x}}$ emissions. Although the CARB standards will not take effect until March 1, 1996, oxygen is restricted prior to that time under a waiver of federal CO-control standards. In New York, there is a similar oxygen limit of $2.7 \mathrm{wt} \%$. Because of the unique nature of the California standards, no compliance margin is included when calculations for RFG sold in California are made.

6 The nine areas in which RFG is required under the CAAA may not opt out.

7 This $55 \%$ is exclusive of spillover from areas with RFG to areas not required to use it. Spillover will occur because the logistics system is not structured to deliver fuel in exact correspondence with ozone nonattainment area boundaries and because there is some commuting into and out of RFG areas. Most spillover estimates are 5\% or lower. This analysis uses an estimated spillover of $1 \%$ for both reformulated and oxygenated gasolines.

8 Gasoline volatility is discussed in terms of Reid vapor pressure, which is the vapor pressure (in pounds per square inch) of a 4:1 (by volume) air-to-fuel mixture at $100^{\circ} \mathrm{F}$. 


\subsection{RENEWABLE OXYGENATE STANDARD}

The ROS requires that 15\% of the oxygen in RFG in 1995 and $30 \%$ of the oxygen in RFG in subsequent years be derived from renewable oxygenates. The phase-in requirement was adopted because the EPA was concerned that ethanol production capacity in 1995 would not be sufficient to supply the total $30 \%$ of required oxygen unless some ethanol were diverted from current uses (e.g., in gasohol). However, the EPA does expect that capacity will be sufficient to meet the $30 \%$ renewable requirement in 1996 and thereafter.

\subsection{OXYGENATES}

Differences in total energy use, fossil energy use, crude oil use, and GHG emissions that result from using different RFGs meeting the same performance standards arise for a number of reasons. The oxygenates used to provide the oxygen content required for RFG vary in density, energy content, mass fraction of oxygen, and volatility, and the GHG emissions and energy use associated with their production and use differ as well. The oxygenates also affect the volume and composition of the hydrocarbon $(\mathrm{HC})$ portion of the RFG.

\subsubsection{Renewable Oxygenates}

There are two criteria that oxygenates must meet to be classified as renewable under the ROS (see EPA 1994a for more details). First, the oxygen source must be renewable. Renewable oxygenates may either be directly blended (e.g., ethanol) or derive their oxygen from a renewable-oxygenate feedstock (e.g., ethanol feed to an ETBE [ethyl tertiary butyl ether] production process). Second, the oxygenate must not have commingling effects if it is to be used to satisfy the renewable requirement during the summer. Commingling effects are nonlinear increases that occur in the Reid vapor pressure (RVP) of RFGs of different composition after they have been mixed. ${ }^{9}$ Increased RVP contributes to increased evaporative emissions of VOCs. ${ }^{10}$ Concern with commingling effects arose during a previous attempt, under the Bush administration, to provide incentives for the use of ethanol in RFG. It was

9 The resulting RVP of the mixture of different RFGs is higher than the arithmetically weighted average of the RVPs of the components of the fuel mixture. Therefore, although it may be more precise to speak of adverse commingling effects, the term "commingling effects" is generally understood to refer to the nonlinear RVP increase, so that interpretation is used in this report.

10 High RVP can also increase HC and $\mathrm{CO}$ exhaust emissions, especially during cold start. Automotive emission control systems are designed for a specific fuel (indolene, since the emissions certification tests employ it). Using a different fuel (or different operating conditions) from the test will affect emissions. Cold-start emissions can be increased by high-RVP fuels because the car runs overly rich under this condition. Thus, the ratio of oxygen to fuel is lower than stoichiometric (i.e., there is less oxygen available than is necessary for complete combustion). The reason that RVP is controlled in the summer, however, is to avoid increased evaporative emissions. 
partly responsible for the rejection of the proposal. (This idea was proposed in 58 FR 11722, Feb. 26, 1993.)

Under the ROS, ethanol use that contributes toward the satisfaction of the renewable requirement will be restricted to the time outside the VOC-control period (including the two transitional, or shoulder, seasons). ETBE is a potential renewable oxygenate for the summer because it does not cause an increase in RVP when blended with gasoline and does not exhibit commingling effects. ${ }^{11}$ The renewable-use season will be referred to henceforth as "winter."12 The VOC-control period will be referred to as "summer." This study assumes that all ethanol used as an oxygenate for RFG will be used during the winter. ${ }^{13}$

\subsubsection{Likely Near-Term Oxygenates}

A number of different oxygenates can be used in RFG, including various alcohols and ethers. Several of the most important oxygenates, as evidenced by their explicit inclusion in the EPA's Complex Model for RFG certification, are MTBE, ethanol, ETBE, and tertiary amyl methyl ether (TAME). This report considers ethanol and ETBE to be renewable oxygenates and MTBE as currently produced to be nonrenewable. RFGs oxygenated with TAME have not been analyzed. MTBE and ethanol are considered the most likely candidates for use in the first several years of the program.

ETBE has lower volatility than MTBE. ETBE's production cost relative to MTBE is largely a function of the relative prices of methanol and ethanol. For purposes of this analysis, it is assumed that before the year 2000, ETBE will generally be prohibitively

11 The blending RVPs of ETBE, MTBE, and ethanol are 4, 8, and 18 pounds per square inch (psi), respectively. Of the three fuels, only ethanol has commingling effects. Blending RVP values depend on the composition of the $\mathrm{HC}$ blendstock and oxygenate concentration but are treated as constants in this report for comparison (NPC 1993, Volume I, Table 3-22). Using lower-RVP oxygenates (such as ETBE during the summer) allows the blending of larger amounts of butane, a high-RVP component, which expands the volume of products derived from a barrel of crude oil. Whether additional blending of butane in the summer actually occurs depends on demand for butane for isobutylene production, direct fuel use (e.g., heating applications), and winter blending in gasoline.

12 Ethanol can be used in the summer as an oxygenate without earning renewable credit. Such use would require a low-RVP HC blendstock.

13 Refiners have indicated that this assumption may not be strictly valid. The transition from etheroxygenated to ethanol-oxygenated RFGs in the summer-to-autumn "shoulder" (transitional) season poses problems because of the hydrophilic nature of ethanol. Therefore, some refiners may choose to produce an $\mathrm{HC}$ blendstock for use with ethanol year-round. 
expensive relative to $\mathrm{MTBE}^{14}$ and that in 2000 and beyond, when more stringent VOC control will be required, ETBE will be a cost-effective renewable oxygenate. The lower volatility of ETBE will help in the attainment of VOC emission targets. It is further assumed that MTBE will still be used in $70 \%$ of the RFG in the year 2000 and beyond. ETBE will be used as a renewable during the summer, and ethanol will be used during the winter.

\subsubsection{Ethanol Demand}

Ethanol has been used as an additive in gasoline since the 1970s. When it constitutes $10 \%$ of the volume of the blend (as typically encountered), the fuel is called gasohol. Each year, about 1.2 billion gallons of ethanol is currently used in gasoline. ${ }^{15}$ The RFG program and the ROS will greatly increase demand for ethanol. Concern about the near-term availability of sufficient ethanol to satisfy the demand under the ROS motivated the $15 \%$ phase-in for 1995.

Ethanol is a candidate as a potential neat or near-neat (E85) alternative fuel. Within the time frames considered in this analysis, little or no use of ethanol as an alternative fuel is expected.

\subsubsection{Ethanol Supply}

This analysis assumes that ethanol is made from corn, whether the ethanol is used as an oxygenate directly or as a feedstock for ETBE production. Ethanol produced from other sourcess (such as cellulose) would result in different energy use and GHG emission profiles. However, these alternative oxygenate sources are not considered because it is assumed that they would be uneconomical or contribute very little (in terms of volume) relative to cornbased ethanol for the period under analysis.

Supply estimates for this study were made on the basis of U.S. Department of Agriculture (USDA) data on operating production capacity and capacity that was under construction and expected to be available by early 1995 . This analysis estimates that approximately 1.4 billion gallons of ethanol production capacity will be available in 1995 .

14 Spot methanol prices underwent large swings in the six months from October 1994 to April 1995 $\$ 1.80$ to $\$ 0.45$, a four-fold difference, per various issues of the New Fuels Report (1993-1994) - while ethanol prices were stable. The data have not been reanalyzed to account for these methanol price swings since the original analysis was performed. When the analysis was conducted, the price of methanol relative to ethanol was more stable.

15 The Federal Highway Administration (FHWA) collected gasohol sales data through 1992 on the basis of state tax revenue data. The 1992 data indicate that about 900 million gallons of ethanol are used in gasoline. The data underrepresent ethanol consumption, however, because some states tax gasohol and gasoline at the same rate and report commingled data. There has also been some growth in gasoline demand since 1992, and there may have been an increase in ethanol use as a fraction of the gasoline pool. These factors lead to a somewhat higher estimate of current fuel ethanol use than that reported by the FHWA in 1992. 
The EPA estimates that 253 million gallons of additional winter ethanol capacity will be available by early 1996 . This study adopts the EPA's estimate. ${ }^{16}$

16 On an annual basis, it scales up the EPA's estimate of incremental winter ethanol capacity to 462 million gallons. 


\section{RENEWABLE OXYGENATE STANDARD AND THE ETHANOL MARKET}

\subsection{INTRODUCTION}

\subsubsection{Motivation for the Study of Ethanol Supply}

Three main concerns exist with respect to the ethanol supply and the ROS: the adequacy of supply, the interstate movement of ethanol (and its implications for credit trading), and the diversion of ethanol from existing use.

\subsubsection{Adequacy of Ethanol Supply}

Approximately 1.4 billion gallons per year of ethanol is currently available from domestic production (approximately 90,000 barrels per day). This production capacity represents current operating capacity plus facilities under construction at the time this analysis was initiated (December 1993).

The EPA has estimated that winter ethanol production capacity will expand by 253 million gallons by 1996. This figure corresponds to about 462 million gallons on an annual basis. The EPA RIA for the ROS also estimates a current excess winter capacity of 80 million gallons (EPA 1994, Table I-3, p. 13). ${ }^{17}$ The EPA does not provide an estimate of ethanol expansion beyond 1996. On the basis of the EPA's capacity expansion estimate, by 1996, about 1.6 billion gallons per year (106 million barrels per day) of ethanol capacity will be available.

The USDA (1988) has estimated that the upper limit of ethanol available from corn feedstocks is approximately 3 billion gallons per year, about twice the current capacity. This limit is derived from an estimate of the maximum amount of anticipated corn crops that can be dedicated to ethanol production. Year-to-year variations in crop yield may influence ethanol availability. Eventually, cellulosic ethanol or other renewable oxygenates may be an economic source of significant volumes of additional ethanol. It is assumed that this situation will not occur in the period under study.

The ROS will require an increase in the use of ethanol of about 380 million gallons per year over current levels, assuming that no ethanol is diverted from current uses outside of RFG areas and that current levels of gasoline demand remain the same. This figure

17 This report estimates a larger current excess ethanol capacity of about 100 million gallons per year. The difference between this report and the RIA occurs because this report relies on a lower estimate of ethanol use when the ROS is not applied and a similar production capacity estimate. 
implies a total demand for approximately 1.6 billion gallons of ethanol. For the phase-in, approximately 80 million additional gallons of ethanol will be required. ${ }^{18}$

Although ethanol capacity can certainly be expanded in the future, and alternative sources of ethanol and other renewable oxygenates may become available in the longer term, during the debate surrounding the ROS rulemaking, the EPA, DOE, and others expressed concern about the adequacy of supplies of ethanol in 1995. Since ethanol can be used as a renewable oxygenate only during a portion of the year, seasonal as well as annual shortages may be of concern. Any annual shortage of ethanol may be exacerbated by the seasonality of the ROS.

\subsubsection{Ethanol Logistics System}

RFG is used primarily in areas that have not used much ethanol in the past. Thus, some incremental transportation of ethanol will be required under the ROS. Although this report is not a study of the logistics system, it includes an estimate of the volumes of ethanol that will need to be transported and diverted from current use to use in RFG as a result of the ROS. It also includes an assessment of the mitigating effect of credit trading on the necessity to transport incremental ethanol. Two assumptions are made:

- Transportation of ethanol or diversion of ethanol from other uses within a contiguous RFG area will impose no incremental transportation burden.

- Transportation of ethanol from non-RFG areas to RFG areas within the same state is ignored because the logistics system is sufficiently flexible to easily accommodate small changes in final destination.

\subsubsection{Diversion of Ethanol from Current Use}

The degree to which the use of ethanol in gasoline will increase as a result of the ROS will depend strongly on ethanol not being diverted from current use to meet the demand created by the ROS. The EPA adopted the phase-in of the ROS to avoid such diversion of ethanol from current use in non-RFG areas.

To establish boundaries for the impact of the ROS on ethanol demand, this analysis estimates the ethanol requirements of the ROS both considering and without considering

18 The additional ethanol required during the phase-in is not 190 million gallons per year (380 million gallons per year divided by two) under the given conditions because there is currently some ethanol used in RFG areas. This current use of ethanol constitutes a larger fraction of ethanol demand during the ROS phase-in than during the full program. During the 30\% program, about $168 \%$ more ethanol will probably be used; during the phase-in, $34 \%$ more ethanol will probably be used. Therefore, incremental ethanol use will probably be five times larger during the remainder of the program than during the phase-in. 
diversion. The preferential use of existing ethanol can lead to its complete diversion from current use in some of the scenarios examined. With no diversion, additional ethanol is required beyond the phase-in period. Intermediate cases between complete diversion and no diversion, while possibly most realistic, are not analyzed.

\subsubsection{Renewable Oxygenate Credit Generation}

Use of renewable oxygenates above the minimum level required under the ROS will result in the generation of negotiable renewable oxygenate credits. It is the responsibility of each refiner to meet the ROS requirement on a calendar-year basis. The unit of accounting for the renewable oxygenate requirement is weight percent-gallons (wt\%-gal). This unit allows RFGs with different oxygen levels to contribute toward satisfying the renewable requirement, weighted by volume. Therefore, oxygenating to more than $2.0 \mathrm{wt} \%$ with renewables, or oxygenating more than 30 vol\% of the RFG with renewables, or both, will result in credit generation.

In practice, refiners may use more ethanol than is required to achieve $2.0 \mathrm{wt} \%$ oxygen to allow for compliance margins or averaging. In an environment in which ethanol is in short supply, refiners are likely to try to trade the credits that they may generate. The credit market for the ROS is currently untested, however, and refiners in need of credits may be reluctant to rely on it to satisfy their renewable oxygenate obligations. This report assumes that credits can be sold and uses $2.0 \mathrm{wt} \%$ oxygen as the basis for calculating the demand for renewable oxygenates.

MTBE-oxygenated RFG is assumed to be at the $2.1 \mathrm{wt} \%$ level predicted in NPC (1993) because credit trading does not apply to nonrenewable MTBE-oxygenated RFG. Although this assumption affects demand for MTBE, this report simply assumes that there will be sufficient MTBE available to meet demand. In practice, this situation is likely in the near term only if some ethanol is used in RFG or if imports of MTBE increase substantially. It is clear that some ethanol is being used in RFG independently of the ROS.

\subsection{METHODOLOGY}

\subsubsection{Demand for Reformulated Gasoline}

RFG demand has been estimated by using population density to approximate gasoline demand. The fraction of each state's population residing within RFG areas is multiplied by the state's gasoline demand. One percent is added to account for spillover.

Gasoline demand projections from DOE's Energy Information Administration (EIA) have been used in this analysis, apportioned by fuel type. Projected 1995 demand was taken from EIA's Short-Term Energy Outlook (STEO) published in the second quarter of 1994. For later years, EIA's Annual Energy Outlook (AEO) published in 1994 was used. 
National gasoline demand was distributed among states in proportion to the states' gasoline use reported in EIA's State Energy Data Report (SEDR) published in 1992. Seasonal changes in overall gasoline demand were not taken into account.

RFG volumes delivering equal energy vary slightly depending on the choice of oxygenate. To deliver an equal amount of energy, any RFG requires approximately $2 \%$ more volume than does conventional gasoline.

\subsubsection{Gasoline and Ethanol Data Sources}

State-level demand for finished fuels (RFG, OG, gasohol, and CG) and ethanol in 1995 is estimated by extrapolation from 1992 sales data on gasohol sales published by FHWA in 1993 and ELA historical gasoline consumption data ${ }^{19}$ (minus the gasohol). These data were then inflated to the appropriate years for the various time frames on the basis of EIA projections.

Gasohol sales are underreported in the FHWA data because they are based on tax revenue, and some states tax gasoline and gasohol at the same rate. In those states, gasohol is counted as part of the gasoline pool. Moreover, the data on total volume of gasoline and gasohol sales reported by the FHWA are larger than the EIA historical data for 1992. Thus, maintaining the fraction of total gasoline demand satisfied by gasohol in 1992 according to FHWA statistics and adjusting the total to agree with EIA data would worsen underreporting of gasohol. For this reason, the FHWA-reported volume of gasohol sold in 1992 is used as a basis and inflated for later years according to EIA projections of growth in total gasoline demand.

Ethanol production capacity estimates for 1995 are based on USDA data. The EPA's projection of additional capacity for 1996 is used for later years. All ethanol production facilities are assumed to operate at $85 \%$ of nameplate capacity.

\subsubsection{Use of Ethanol in Nonreformulated Oxygenated Gasoline and Gasohol}

The EIA reports that in 1994, about $30 \%$ of OG was oxygenated with ethanol. (This statistic presumably includes any OG demand satisfied by gasohol sales.) On the basis of the population of $\mathrm{CO}$ nonattainment areas that participated in the federal OG program during the 1993-1994 winter season, ${ }^{20}$ this report estimates that there is a demand for about

19 In 1993, the EIA adjusted its statistic on the volume of gasoline supplied to include blend stocks and alcohols. A 1993-basis adjusted volume for 1992 was subsequently published and is the value used in this analysis to make the EIA data consistent with the FHWA data.

20 A number of $\mathrm{CO}$ nonattainment areas have never participated in the OG program or have withdrawn from the program since the first season in which it was in effect (winter 1992-1993). It is possible that other regions will stop using $\mathrm{OG}$ in favor of other $\mathrm{CO}$ attainment strategies (e.g., enhanced inspection and maintenance), but it is unlikely that areas that have left the program will choose to use OG. Hence, this report uses the 1993-1994 winter program participation as a basis for estimating OG demand. 
14 billion gallons of OG over an assumed average CO-control season of five months. About $65 \%$ of this demand is from areas that require RFG and would be satisfied by use of OPRG.

Data on the estimated volume of OG demand and the fraction of OG oxygenated with ethanol imply that there will be a demand for between 325 and 420 million gallons of ethanol for OG in winter 1995, without the ROS and the RFG program, depending on the amount of OG demand that is satisfied by gasohol. The lower number implies that $30 \%$ of OG is oxygenated to $2.7 \mathrm{wt} \%$ oxygen with ethanol (i.e., no OG demand is satisfied by gasohol). The higher number implies that $30 \%$ of $O G$ is oxygenated to $3.5 \mathrm{wt} \%$ oxygen (i.e., all OG demand is satisfied by gasohol).

On the basis of data on gasohol sales by state and on ethanol use in CO nonattainment areas using OG, this report estimates that demand for ethanol in gasohol and OG would be 1.18 billion gallons per year without the ROS and the RFG program. For this calculation, ethanol was apportioned among the various $O G$ areas according to data from the EPA and Information Resources, Inc. (IRI). EPA data were used to estimate ethanol use in the Northeast; IRI data were used for other areas. The total volume of OG oxygenated with ethanol according to this apportionment closely matches the aggregate estimate of EIA.

Of the 1.18 billion gallons of ethanol demand in the absence of the ROS and RFG program, 0.92 billion gallons per year would be used in gasohol, and 0.26 billion gallons per year would be used in $\mathrm{OG}$ at $2.7 \mathrm{wt} \%$ oxygen. The OG volume is the difference between total $O G$ demand and the volume of gasohol expected to be sold in OG areas during the CO-control period. The tables in Appendix B contain the relevant data.

\subsubsection{Seasonal Oxygenate-Use Case Descriptions}

\subsubsection{12-Month, Year-Round Case}

The 12-month case represents the ethanol utilization rates that would result if refiners were to oxygenate year-round with renewable oxygenates (with ethanol during the winter and ETBE during the summer) to $2.0 \mathrm{wt} \%$ oxygen in $30 \%$ of the RFG (15\% during the first year). The total volume of RFG differs slightly from that estimated on the basis of winter-only use of renewable oxygenates because of the differing densities and energy contents of ethanol and ETBE.

\subsubsection{6.5-Month, Winter-Only Case}

The 6.5-month case represents the use of ethanol only during the winter. The length of the season has been chosen to agree closely with the RIA estimate of a 197-day RFG 
winter season. ${ }^{21}$ Because annual renewable oxygenate obligations are to be satisfied on a calendar-year basis, this case leads to a bipartite winter season. The first part runs from January through the end of March, and the second part runs from mid-September through the end of December, in agreement with the division of the year used in the RIA (EPA 1994a).

\subsubsection{3-Month, Front-Loaded Case}

The 3-month, or front-loaded, case represents an extreme in monthly ethanol demand in which refiners would attempt to satisfy annual renewable oxygenate obligations during the first part of the winter (Jan.-Mar.). Although it is unlikely that all refiners would do this, individual refiners, particularly those outside Petroleum Administration Defense District (PADD) II (Chicago area), might attempt to satisfy the ROS requirement during the first part of the winter season to avoid being caught short at the end of the year. Front loading effectively tightens ethanol supply during the first part of the winter. Some front loading is likely during the first year of the program because many refiners lack experience with ethanol and because the market for renewable-oxygenate credits is untested. A front-loaded case is also possible during future ethanol supply disruptions.

\subsubsection{Time Frames Considered}

The impact of the ROS on ethanol demand and disposition is analyzed in three time frames: the first year of the program (1995), near term (1996 through 1999), and long term (2000 and after). RFG program participation as of March 1995 is assumed for each time frame (as discussed in Section 1.2.2).

\subsubsection{First Year}

During the first year, the assumption is that there will be a $15 \%$ phase-in of the ROS, RFG demand will be at 1995 levels, and there will not be significant ETBE use. Two seasonal cases are considered in the first year of the renewable oxygenate program - winter only ( 6.5 months) and front-loaded (3 months).

The actual first year will probably be intermediate between the 6.5-month and 3-month cases. If ETBE is used more widely than assumed during the first year, summer may also be available for substantial use of renewable oxygenates, which would tend to lengthen the renewable season.

21 The effective winter season may be somewhat shorter in practice for some refiners. In particular, 6.5 months may be too long for Gulf Coast refiners serving markets in the Northeast. 


\subsubsection{Near Term}

In the near term, the full 6.5-month winter season is assumed to be available for ethanol blending to satisfy the ROS (i.e., no front loading). It is assumed that ETBE will not be available in sufficient quantities for use as a renewable oxygenate in summer. RFG demand for 1995 is used for the near term to reduce the number of calculations and facilitate comparison with the first year. ${ }^{22}$

It is likely that ethanol production capacity will expand over the period if the ROS goes into effect. Ethanol production capacity in 1996 is estimated on the basis of the RIA. Beyond 1996, ethanol capacity is assumed to be an unpredictable function of economic conditions.

\subsubsection{Long Term}

In 2000 and beyond, it is assumed that year-round oxygenation with renewables will be practical by using ETBE during the summer and ethanol during the winter. The Phase II RFG standards for VOCs will probably make ETBE attractive because of its low blending RVP. Data on RFG demand for the long term are derived from the EIA's data on projected gasoline demand for 2000.

Expansion of ethanol production capacity and an increase in the number of ethanolto-ETBE facilities could occur between the present and the long-term time frame if the economics are favorable. The EIA's current unpublished forecasts for the 1995 AEO indicate a large and growing role for ETBE in 2000 and beyond.

\subsubsection{Credit-Trading Analysis}

Credit trading can reduce or eliminate the burden of ethanol blending on those refiners who prefer not to use ethanol. By relying on the credit market, however, refiners lose some control over the composition of their products, particularly toward the end of the calendar year when ROS credits must be balanced.

Credit trading is analyzed by distinguishing between those states likely to be net credit sellers and net credit buyers. This analysis assumes that refiners supplying RFG to PADD II RFG areas are the most likely net credit sellers, because consumers in that region are familiar with ethanol. Potential net credit buyers are assumed to be all others.

To assess the potential of credit trading to mitigate pressures of the logistics system, a maximum credit-trading scenario has been created, in which refiners supplying PADD II (i.e., the net credit sellers) have a surplus of renewable credits to trade. (PADD II states with

22 The EIA (1994 AEO) projects an increase in gasoline demand of approximately 5\% over the nearterm period. 
RFG areas include Illinois, Indiana, Wisconsin, and Kentucky; the Chicago area is the major RFG market in PADD II). In these markets, the assumption is that $90 \%$ of the RFG will be oxygenated with renewable oxygenates to the maximum allowable.oxygen level during the applicable season (i.e., ethanol to $3.5 \mathrm{wt} \%$ oxygen during winter; ETBE to $2.7 \mathrm{wt} \%$ oxygen during summer). States with RFG areas outside PADD II are assumed to use the minimum required level of ethanol in all RFG and to use no ethanol outside the RFG pool. The EPA has indicated that it "did not intend to give credit to renewable use in conventional areas" (EPA 1994b, Oct. 17, answer to Q6 under the heading "Renewable Oxygenate Program"). Therefore, the small (1\%) spillover volume assumed in this analysis has not been included in the credit generation calculations.

It may be possible to use renewable oxygenates in more than 90\% of PADD II RFG. However, particularly during the beginning of the program, outstanding MTBE contracts or other factors may constrain the use of renewable oxygenates. Maximum renewable use in this sense establishes the minimum necessary level of incremental ethanol movement.

\subsection{RESULTS}

\subsubsection{Seasonal Analysis Results}

Table 2.1 summarizes the net national supply of and demand for ethanol for each of the seasonal cases $(12,6.5$, and 3 months) in each of the three time frames analyzed (first year, near term, and long term).

- Ethanol that would have been used within RFG areas in the absence of the RFG program is assumed to be used in RFG but is not counted in the calculation of diversion. On a 12-month basis, 224 million gallons of ethanol are being used within RFG areas without the ROS. The portion of this ethanol used during the winter, 121 million gallons, would apply toward meeting the ROS in the first year and near term. The full amount is credited as renewable for year-round renewable use in the long-term analysis.

- Estimated ethanol production capacity for 1995 is used for the first year; 1996 capacity is used for the near term and long term.

- Net supply implies that ethanol production capacity is in excess of demand. Net demand implies that ethanol production capacity is insufficient to meet demand.

The presentation of results for a 12-month renewable utilization period during the first year and near term is not meant to imply that year-round, renewable oxygenate use is expected during these periods. A longer ethanol blending season or early use of ETBE by some refiners could produce an intermediate case between the 6.5 month and 12-month cases. 
TABLE 2.1 Seasonal Results ${ }^{\mathrm{a}}$

\begin{tabular}{cccccc}
\hline A & B & C & D & E & F \\
\cline { 2 - 5 } & & Ethanol $\left(10^{6}\right.$ gal $)$ & Ethanol to Be \\
$\begin{array}{c}\text { Utilization } \\
\text { Period for } \\
\text { Ethanol in } \\
\text { RFG (mo) }\end{array}$ & $\begin{array}{c}\text { Production } \\
\text { Capacity } \\
\text { over Period }\end{array}$ & $\begin{array}{c}\text { Amount } \\
\text { Required } \\
\text { to Satisfy } \\
\text { ROS }\end{array}$ & $\begin{array}{c}\text { Demand } \\
\text { outside. } \\
\text { RFG Areas } \\
\text { over Period }\end{array}$ & $\begin{array}{c}\text { Net Supply } \\
\text { (Demand) } \\
\text { over Period }\end{array}$ & $\begin{array}{c}\text { Diverted from } \\
\text { Non-RFG Pool } \\
\text { to Satisfy ROS } \\
\text { (\%) }\end{array}$ \\
\hline
\end{tabular}

First Year: RFG with 15\% Renewables

$\begin{array}{rrrrrr}12 & 1,368 & 300 & 959 & 108 & 0 \\ 6.5 & 741 & 300 & 520 & (79) & 15^{\mathrm{c}} \\ 3 & 342 & 300 & 240 & (198) & 83\end{array}$

Near Term: RFG with 30\% Renewables

$\begin{array}{rrrrrr}12 & 1,830^{d} & 601 & 959 & 270 & 0 \\ 6.5 & 991^{\text {d }} & 601 & 519 & (129) & 25 \\ 3 & 457^{\text {d }} & 601 & 240 & (384) & >100^{\text {e }}\end{array}$

Long Term: RFG with 30\% Renewables

\begin{tabular}{rrrccc}
12 & 1,830 & 630 & 1,004 & 195 & 0 \\
6.5 & 991 & 630 & 544 & $(183)$ & 34 \\
\hline
\end{tabular}

a Columns $\mathrm{A}$ through $\mathrm{D}$ are either data inputs or calculated by the spreadsheet model; $\mathrm{E}=\mathrm{B}-\mathrm{C}-\mathrm{D}$; and $\mathrm{F}=$ the greater of $-\mathrm{E} / \mathrm{D}$ and 0 .

b 1995 basis is used for first year; 1996 basis is used for near term and long term.

c Small percentage diversion values should be considered in light of several potentially mitigating factors: inventory may be available to satisfy seasonal shortfall, inventory levels may change over time, season lengths may be slightly different than has been assumed, there could be more opt-out areas, and so on.

d The EPA's projection of 1995-1996 winter ethanol production capacity expansion (EPA 1994a) - (250 million gallons of winter ethanol capacity - has been treated as 460 million gallons per year for the 12-month case to be consistent with the EPA's assumption about winter length (both values rounded).

e Even though all ethanol would be diverted from the gasohol and OG pools, ethanol production capacity would not be sufficient to meet the requirements of the ROS in this case. Approximately $32 \%$ of additional ethanol capacity would be required to satisfy only the ROS over the period. 


\subsubsection{First Year}

\section{2-Month Analysis}

- Over the period, there will be an excess of 108 million gallons of ethanol, given 1995 capacity and an unchanged level of ethanol demand in areas not using RFG during the $15 \%$ phase-in.

- If demand for ethanol in the gasohol and OG markets is not met, there will be an excess supply of 1.068 billion gallons.

- Meeting the ethanol demand that results from the RFG program would not require a reduction in use of ethanol for $O G$ and gasohol during the period.

\section{5-Month Analysis}

- Over the period, there will be a shortage of 79 million gallons of ethanol, given current ethanol capacity and an unchanged level of ethanol demand in areas not using RFG.

- If demand for ethanol in the gasohol and OG markets is not met, there will be an excess supply of 441 million gallons.

- Meeting the ethanol demand that results from the RFG program would require a $15 \%$ reduction in use of ethanol for $\mathrm{OG}$ and gasohol during the period.

\section{3-Month Analysis}

- Over the period, there will be a shortage of 198 million gallons of ethanol, given current ethanol capacity and an unchanged level of ethanol demand in areas not using RFG.

- If demand for ethanol in the gasohol and OG markets is not met, there will be an excess supply of 42 million gallons.

- Meeting the ethanol demand that results from the RFG program would require an $83 \%$ reduction in use of ethanol for $O G$ and gasohol during the period. 


\subsubsection{Near Term}

\section{2-Month Analysis}

- There will be an excess of 270 million gallons of ethanol, given 1996 capacity and an unchanged level of ethanol demand in areas not using RFG.

- If demand for ethanol in the gasohol and OG markets is not met, there will be an excess supply of 1.229 billion gallons.

- Meeting the ethanol demand that results from the RFG program would not require a reduction in use of ethanol for $O G$ and gasohol during the period.

\section{5-Month Analysis}

- Over the winter, there will be a shortage of 129 million gallons of ethanol, given expected ethanol capacity and an unchanged level of ethanol demand in areas not using RFG.

- If demand for ethanol in the gasohol and OG markets is not met, there will be an excess supply of 390 million gallons.

- Meeting the ethanol demand that results from the RFG program would require a $25 \%$ reduction in use of ethanol for $O G$ and gasohol during the period.

\section{3-Month Analysis}

- Over the front-loaded period, there will be a shortage of 384 million gallons of ethanol, given expected ethanol capacity and an unchanged level of ethanol demand in areas not using RFG.

- Even if demand for ethanol in the gasohol and OG markets is not met, there will still be a shortage of 144 million gallons of ethanol to meet the ROS requirements (on the basis of the 1996 ethanol capacity level).

- Meeting ethanol demand that results from the RFG program would require the elimination of all ethanol in gasohol and OG during the period and an increase in production capacity of $32 \%$ (or an equivalent increase in inventory). 


\subsubsection{Long Term}

Diversion is unlikely in this time frame, even for the 6.5-month season, because there is ample time to expand ethanol capacity or inventory. However, rather than forecast such expansion, the long-term analysis was conducted on the basis of estimated 1996 ethanol production capacity. Also, the front-loaded case was eliminated in the long-term analysis because it assumes that reliable ethanol supply patterns and an established credit-trading market will exist in a mature program.

\subsubsection{Likely Program Operation}

For the 15\% phase-in for the first year, approximately $41 \%$ of 1995 winter ethanol capacity would be required to satisfy the ROS over a 6.5-month season. Of the ethanol use required to satisfy the ROS, $40 \%$ would be used in the absence of the RFG program in RFG areas. Ethanol use during the winter would increase by 2.5 times in RFG areas as a result of the ROS. Meeting ethanol demand due to the ROS as well as demand due to the use of gasohol and OG outside RFG areas would require about 80 million gallons of ethanol more than could be produced over the 6.5-month period.

The 6.5-month case, which represents the likely operation of the ROS during Phase I of the RFG program after the first year, would require utilization of about $61 \%$ of the ethanol production capacity at 1996 capacity to satisfy the ROS alone. This result suggests that capacity or inventory expansion will be necessary to avoid diverting the use of ethanol from gasohol and OG to RFG for the mature program.

If ethanol demand outside RFG areas were to be met, total ethanol demand during the 6.5-month period would be 1.120 billion gallons for the $30 \%$ program in the near term. This amount is approximately $13 \%$ more than 1996 production capacity over the period (991 million gallons) and so would require drawdown of inventory or additional expansion of capacity.

Ethanol stocks ranged from 75 to 120 million gallons during 1993 (ELA 1994, Table D.2). This figure suggests that a working inventory of about 50 million gallons would be available for drawdown. Meeting the demands of both the ROS and the gasohol/OG markets would require a 2.5 -fold increase in working inventory if the shortfall over the 6.5-month period were to be supplied by using the inventory.

The long-term operation of the program does not appear to present significant supply or diversion problems.

\subsubsection{Regional Analysis Results (Credit Trading/Ethanol Transport)}

The results are summarized in Tables 2.2 and 2.3. The credit-trading analysis suggests that further study of the logistics system is warranted to determine the relevance of incremental ethanol transportation. Although volumes are reported in Tables 2.2 and 2.3, 
TABLE 2.2 Maximum Generation of Credits ${ }^{\mathrm{a}}$

A

\begin{tabular}{ccc} 
& \multicolumn{2}{c}{ Ethanol $\left(10^{6} \mathrm{gal}\right)$} \\
\cline { 2 - 3 } & Maximum Used & Required in \\
Period of Credit & in PADD II RFG & PADD II \\
Generation & $(90 \%$ of RFG at & under \\
(mo $)^{c}$ & $3.5 \mathrm{wt} \%)$ & ROS $^{\mathrm{d}}$
\end{tabular}

C D

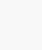

First Year: RFG with 15\% Renewables

$\begin{array}{rrrr}12 & 384 & 41 & 343 \\ 6.5 & 233 & 41 & 192 \\ 3 & 107 & 19 & 88\end{array}$

Near Term: RFG with 30\% Renewables

$\begin{array}{rrrr}12 & 384 & 81 & 303 \\ 6.5 & 233 & 81 & 152 \\ 3 & 107 & 38 & 69\end{array}$

Long Term: RFG with 30\% Renewables

\begin{tabular}{rlll}
12 & 405 & 87 & 318 \\
6.5 & 246 & 87 & 159 \\
\hline
\end{tabular}

a Column $\mathrm{A}=$ spreadsheet input; column $\mathrm{B}=0.9$ times the volume of ethanol required to oxygenate all PADD II RFG to $3.5 \mathrm{wt} \%$ oxygen (2.7 wt\% during summer) over the period in column $\mathrm{A}$; column $\mathrm{C}=0.15$ times the volume of ethanol required to oxygenate all PADD II RFG to $2.0 \mathrm{wt} \%$ oxygen over the period; column $\mathrm{D}=\mathrm{B}$ minus $\mathrm{C}$.

b For 12-month cases, the ethanol equivalent of ETBE is reported for summer months.

c It is unlikely that refiners in the ethanol producer states (in general, net credit sellers) will be limited to the 3 -month period for generation of renewable oxygenate credits. However, credit purchasers could perceive a potential shortage of credits later in the year and be unwilling to risk waiting to balance their ROS credits. At some point, escalation in the price of ethanol would result in a reduction in nearterm demand for ethanol (i.e., some refiners would decide that on the basis of market rates for ethanol, it would be worthwhile to wait until the second part of the winter season to buy ROS credits).

d To balance credits in the 12- or 6.5-month cases, net-credit-selling refiners must fulfill the full year requirement for renewable oxygenate use over the period in question. Otherwise, in effect, they buy credits

Footnote d continued on next page 
Footnote $\mathrm{d}$ from Table 2.2 (Cont.)

from themselves. Since the 3 -month case arises as a result of a potential shortage of ethanol perceived by credit buyers rather than an actual shortage of ethanol, PADD II refiners can satisfy their ethanol demand over the 3-month period by using $46 \%$ of the yearly requirement and can sell the surplus. The assumption is that the rate of required ethanol use over both parts of the winter is constant. The credit market could be potentially more complex than this constant rate of credit accrual implies. For example, if ethanol prices were to rise in a front-loaded case, producer-state refiners might sell all their generated ROS credit speculatively and postpone taking ROS credits for their required volume of ethanol until the second part of the winter season.

TABLE 2.3 Net Ethanol Movement ${ }^{\text {a }}$

\begin{tabular}{|c|c|c|c|c|c|}
\hline \multirow[b]{3}{*}{$\begin{array}{c}\text { Period of } \\
\text { Credit } \\
\text { Generation }\end{array}$} & B & $\mathbf{C}$ & $\mathbf{D}$ & $\mathbf{E}$ & F \\
\hline & \multicolumn{5}{|c|}{ Ethanol $\left(10^{6} \mathrm{gal}^{\mathrm{b}}\right.$} \\
\hline & $\begin{array}{l}\text { Gross Use } \\
\text { Required to } \\
\text { Meet Annual } \\
\text { ROS outside } \\
\text { PADD II }\end{array}$ & $\begin{array}{c}\text { Available } \\
\text { Credit } \\
\text { from } \\
\text { PADD II }\end{array}$ & $\begin{array}{c}\text { Net } \\
\text { Required } \\
\text { outside } \\
\text { PADD II } \\
\text { under ROS }\end{array}$ & $\begin{array}{c}\text { Current Use } \\
\text { in RFG } \\
\text { Areas } \\
\text { outside } \\
\text { PADD II }\end{array}$ & $\begin{array}{c}\text { Incremental } \\
\text { Transport } \\
\text { to Satisfy } \\
\text { ROS Only }\end{array}$ \\
\hline \multicolumn{6}{|c|}{ First Year: RFG with 15\% Renewables } \\
\hline $\begin{array}{r}12 \\
6.5 \\
3\end{array}$ & $\begin{array}{l}260 \\
260 \\
260\end{array}$ & $\begin{array}{r}343 \\
192 \\
88\end{array}$ & $\begin{array}{r}-83 \\
68 \\
172\end{array}$ & $\begin{array}{l}95 \\
52 \\
24\end{array}$ & $\begin{array}{r}-178 \\
16 \\
148\end{array}$ \\
\hline \multicolumn{6}{|c|}{ Near Term: RFG with 30\% Renewables } \\
\hline $\begin{array}{r}12 \\
6.5 \\
3\end{array}$ & $\begin{array}{l}519 \\
519 \\
519\end{array}$ & $\begin{array}{r}303 \\
152 \\
69\end{array}$ & $\begin{array}{l}216 \\
367 \\
450\end{array}$ & $\begin{array}{l}95 \\
52 \\
24\end{array}$ & $\begin{array}{l}121 \\
315 \\
426\end{array}$ \\
\hline \multicolumn{6}{|c|}{ Long Term: RFG with 30\% Renewables } \\
\hline $\begin{array}{r}12 \\
6.5\end{array}$ & $\begin{array}{l}544 \\
544\end{array}$ & $\begin{array}{l}318 \\
159\end{array}$ & $\begin{array}{l}226 \\
385\end{array}$ & $\begin{array}{l}95 \\
52\end{array}$ & $\begin{array}{l}131 \\
333\end{array}$ \\
\hline
\end{tabular}

a Column $\mathrm{A}=$ data input; $\mathrm{B}=$ calculated by spreadsheet model; $\mathrm{C}=$ calculated in Table 2.2; $\mathrm{D}=\mathrm{B}-\mathrm{C} ; \mathrm{E}=$ calculated in spreadsheet model; and $\mathrm{F}=\mathrm{D}-\mathrm{E}$.

b For 12-month cases, the ethanol equivalent of ETBE is reported for summer months.

c This accounts only for interstate movement from PADD II to other RFG states.

Ethanol might be redistributed among states with and without RFG areas, and modes and distances of transportation might change under such redistribution. 
the unit of renewable-credit accounting is wt\%-gal. Physical units are reported for ease of use in the analysis of necessary incremental ethanol transportation. The credit-trading (and incremental transportation) results obtained when volumes are used as the unit of measure are the same as those calculated when wt\%-gal is used (i.e., conversion of units is implicit). For example, in the 12-month case in Table 2.2 for the first year, maximum renewable use (with $90 \%$ of RFG oxygenated with renewables to $3.5 \mathrm{wt} \%$ during the winter and $2.7 \mathrm{wt} \%$ during the summer), as calculated from the 1995 PADD II RFG demand of 4.771 billion gallons, is 13.45 billion wt\%-gal. During the first year (15\% at $2.0 \mathrm{wt} \%$ oxygen), 1.43 billion wt\%-gal is required, leaving 12.02 billion wt\%-gal, or $89.4 \%$, available for trade. This value agrees closely with the percentage available as calculated by using the volume-equivalent units reported in Table 2.2.

\subsubsection{Conclusions}

- There is likely to be diversion of ethanol early in the program, particularly if there is some front loading.

- The front-loaded case would require nearly all the ethanol to be diverted during the $15 \%$ phase-in. In the case of a full 6.5-month winter ethanol blending season, satisfying the ethanol demand due to the ROS by use of production capacity only would result in a 15\% diversion of ethanol from non-RFG markets. A combination of maximum inventory drawdown and full production capacity utilization would reduce diversion to $5 \%$.

- The ethanol required to meet the ROS would exceed the supply available from production and inventory in the front-loaded case for the $30 \%$ program in 1996. About $25 \%$ of the ethanol would need to be diverted during the 6.5-month ethanol season, at full use of production capacity but no use of inventory. With maximum inventory drawdown in addition to full capacity utilization, as little as $15 \%$ of the ethanol would need to be diverted over the winter.

- Diversion is unlikely in the long term because there is ample time for the expansion of ethanol production capacity and because front loading is unlikely in that time frame.

- Credit trading will not eliminate the need for some incremental ethanol transportation to RFG markets that had not used much ethanol before.

- A study of the ethanol logistics system will be necessary to determine the significance of increased ethanol transport to blending facilities in RFG areas that had not used much ethanol before.

- Ethanol production capacity or inventory will have to be expanded to satisfy ethanol demand related to the ROS. 


\section{ENERGY USE AND GREENHOUSE GAS EMISSIONS OF REFORMULATED GASOLINE}

\subsection{METHODOLOGY}

\subsubsection{Analytical Framework}

Figure 3.1 shows the overall framework for the analysis described in this report. This analysis estimates the volume and type of feedstock (e.g., crude oil, alcohol, isobutylene) required for the gasoline and oxygenate components in each RFG. It estimates the process energy required to refine the crude oil to produce the HC portion of the finished RFG and the process energy required to produce the alcohols, isobutylene, and ethers for the oxygenates. It distinguishes the energy used to produce the RFG components and the energy embodied within the components from each other. Material and energy balances derived from these estimates allow the calculation of the composite energy and crude oil requirements of RFG oxygenated with MTBE, ethanol, or ETBE.

The GHG emissions of the various RFGs are also estimated. These estimates include GHG emissions associated with both the production of RFG feedstocks and the use of RFG. The evaluation of the energy and crude oil requirements and GHG emissions of the various RFGs is made on an equal-energy-delivery basis. The volume of each RFG is normalized, so that use of each fuel results in the same vehicle miles of travel (VMT).

\subsubsection{Refinery Modeling}

Two refinery models were used in this analysis to develop estimates of the energy and crude oil required to produce various RFGs. The Turner, Mason \& Company (TM) refinery linear programming (LP) model was used to generate most of the refinery-related inputs to this study. The results of the TM refinery LP model runs were reported in the NPC (1993). Runs of a LP model used by Oak Ridge National Laboratory (ORNL) were used to derive the estimate of the energy required to produce winter RFG with ethanol.

The TM refinery LP model was used to model RFGs produced in a typical Petroleum Administration Defense District (PADD) complex refinery. ${ }^{23}$ The district chosen (PADD II, Chicago area) is one of nine required to use RFG and a key market for ethanol sales. Although RFG production varies among PADDs, the general trend indicated in the results below would probably be the same for other PADDs. ORNL's model uses refineries in PADD III as its basis. PADD III includes Texas, New Mexico, Louisiana, Mississippi, Alabama, and Arkansas.

23 NPC (1993) distinguishes between "simple" and "complex" refineries. Simple refineries have little or no ability to change the boiling range of the material they process. Complex refineries can convert material from one boiling range to another (EIA 1990, p. 8). 


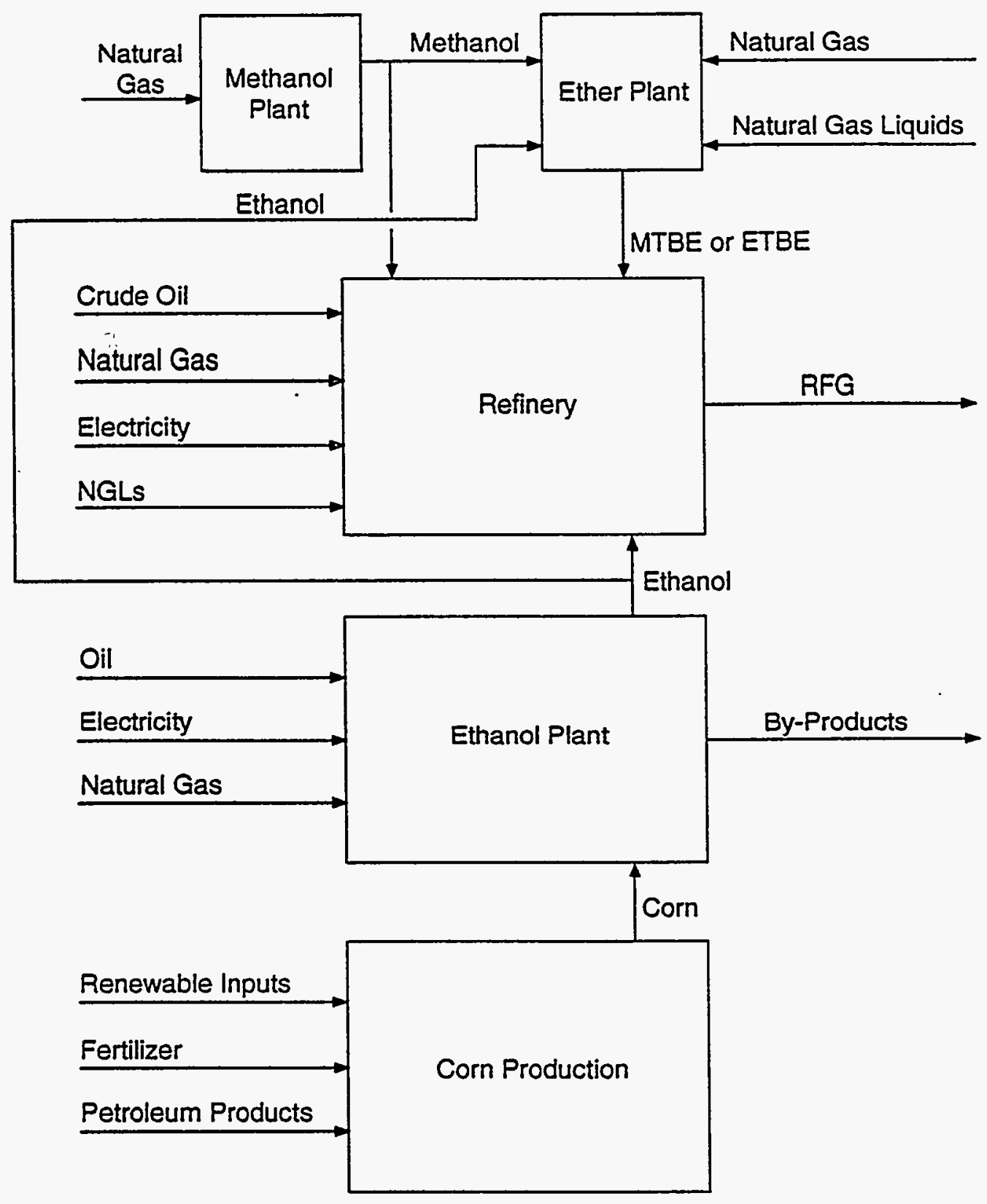

FIGURE 3.1 Overall Framework Employed in Analysis of Energy and Oil Requirements for RFG Production 
The RFGs analyzed are year 2000 summer (VOC-controlled) and winter RFGs. They contain a minimum of $2.1 \mathrm{wt} \%$ oxygen (the averaging standard). The baseline fuel used in this analysis (base RFG) is summer RFG with MTBE, the oxygenate most likely to be used in the production of RFG. When compared with CAAA baseline CG, this RFG reduces VOC emission levels by $27-41 \%$, depending on whether the February 1993 or April 1992 version of the EPA's complex model is used. ${ }^{24}$ The EPA has developed this model for use in implementing the RFG program. The characteristics of this summer RFG with MTBE are indicated in Table 3.1. The refinery-related energy and crude oil inputs needed to produce this gasoline were calculated by TM.

Once the estimates for the summer RFG with MTBE were made, the constraints on the TM refinery LP model were changed to reflect a mixed RFG pool. In the mixed pool, 70\% of the RFG uses MTBE as the oxygenate and $30 \%$ uses ethanol; both RFGs contain $2.1 \mathrm{wt} \%$ oxygen, the level that is consistent with the requirements of the February 1993 EPA Notice of Proposed Rulemaking (NPRM). (In the NPRM, the EPA proposed to allow RFG with ethanol to meet a less stringent VOC reduction standard.) The characteristics of this mixed RFG pool are also described in Table 3.1. The VOC performance of the mixed RFG pool was held to the original $41 \%$ reduction per the April 1992 version of the EPA complex model. The total energy content of the RFG produced daily (i.e., daily volume multiplied by specific energy content) and volumes and characteristics of key non-RFG products (e.g., diesel fuel) were held constant. The refinery model was allowed, within these constraints, to optimize production on the basis of cost. Energy and crude oil input requirements were then recalculated.

The TM refinery LP model was also used to estimate the energy and crude oil inputs needed to produce most of the winter gasolines considered in this study. TM developed estimates for winter CG and for a mixed pool of winter CG, OG, and RFG with MTBE as the oxygenate. VOC reduction is not specified since required VOC reduction applies only to the high ozone season. TM did not have an LP run with ethanol as a winter RFG oxygenate. The ORNL LP model provided estimates of the energy and crude oil inputs required to produce (1) a mixed pool of winter CG and RFG completely oxygenated with MTBE and (2) another mixed pool of winter CG and RFG oxygenated with both MTBE (70\%) and ethanol (30\%). Selected characteristics of the winter RFGs in these combined fuel pools are shown in Table 3.2.

From all these runs, estimates of the energy and crude oil input required to produce summer and winter RFG with MTBE and winter RFG with ethanol can be derived. The derivation is explained in Section 3.4. No runs assume use of ETBE as an oxygenate. Other available LP model runs that evaluated the energy and crude oil impacts of changes in the RVP of the HC portion of the RFG have been used to approximate the changes in the RFG

24 This portion of the analysis was completed before December 1993, when the complex model was finalized. The VOC reduction of the baseline RFG used in this analysis has not been reestimated. 
TABLE 3.1 Characteristics of Selected Summer RFGs Used in PADD II

\begin{tabular}{|c|c|c|}
\hline Item & $\begin{array}{c}\text { RFG with } \\
\text { MTBE } \\
\text { (Case S6) }\end{array}$ & $\begin{array}{c}\text { Combined Pool of } \\
\text { RFGs: } 70 \% \text { Use } \\
\text { MTBE; 30\% Use } \\
\text { Ethanol } \\
\text { (Case S13H) }\end{array}$ \\
\hline \multicolumn{3}{|l|}{ Properties } \\
\hline Aromatics (vol\%) & 23.9 & 23.6 \\
\hline Oxygen (wt\%) & 2.1 & 2.1 \\
\hline Olefins (vol\%) & 10.3 & 10 \\
\hline Benzene (vol\%) & 0.7 & 0.7 \\
\hline Sulfur (ppm by weight) & 236 & 86 \\
\hline RVP (psi) & 6.6 & 6.8 \\
\hline $\mathrm{T} 50\left({ }^{\circ} \mathrm{F}\right)^{\mathrm{b}}$ & 208 & 209 \\
\hline $\mathrm{T} 90\left({ }^{\circ} \mathrm{F}\right)^{\mathrm{b}}$ & 342 & 327 \\
\hline EVAP at $200^{\circ} \mathrm{F}(\%)^{\mathrm{c}}$ & 47.8 & 47.4 \\
\hline $\mathrm{EVAP}$ at $300^{\circ} \mathrm{F}(\%)^{\mathrm{c}}$ & 81.5 & 84.8 \\
\hline \multicolumn{3}{|l|}{$\begin{array}{l}\text { Emission reduction from } \\
\text { statutory base }(\%)^{\mathrm{d}}\end{array}$} \\
\hline VOCs & 41 & 41 \\
\hline $\mathrm{NO}_{\mathrm{z}}$ & 0 & 5 \\
\hline & 33 & 39 \\
\hline
\end{tabular}

a $\mathrm{ppm}=$ parts per million.

b $\mathrm{T} 50$ = temperature at which $50 \%$ of the gasoline sample evaporates. T90 $=$ temperature at which $90 \%$ evaporates.

c $\mathrm{EVAP}=$ percent evaporated at $200^{\circ} \mathrm{F}$ or $300^{\circ} \mathrm{F}$, as appropriate.

d Per the April 1992 version of the EPA's complex model. Fuel properties were set prior to the issuance of $\mathrm{NO}_{\mathrm{x}}$ standards for Phase 2 of the RFG program (Phase 2 standards) and publication of the final complex model. To reduce $\mathrm{NO}_{\mathrm{x}}$ sufficiently to make these RFGs comply with the $\mathrm{NO}_{\mathrm{x}}$ standard would probably require further hydrodesulfurization, which could affect the energy and crude oil requirements and GHG emissions of the fuels.

e TAPs = toxic air pollutants.

Source: NPC (1993, Volume 5, Table F-1). 
TABLE 3.2 Characteristics of Selected Winter RFGs

\begin{tabular}{|c|c|c|c|c|}
\hline Properties & $\begin{array}{c}\text { RFG with } \\
\text { MTBE in } \\
\text { TM Case } \\
\text { Q6W }\end{array}$ & $\begin{array}{l}\text { RFG with } \\
\text { MTBE in } \\
\text { ORNL PADD } \\
\text { III Analysis: } \\
\text { All RFG } \\
\text { Uses MTBE }\end{array}$ & $\begin{array}{l}\text { RFG with } \\
\text { MTBE in } \\
\text { ORNL PADD } \\
\text { III Analysis: } \\
\text { 30\% of RFG } \\
\text { Uses Ethanol }\end{array}$ & $\begin{array}{l}\text { RFG with } \\
\text { Ethanol in } \\
\text { ORNL PADD } \\
\text { III Analysis: } \\
30 \% \text { of RFG } \\
\text { Uses Ethano }\end{array}$ \\
\hline Aromatics (vol\%) & 18.2 & 25.2 & 25.0 & 23.2 \\
\hline Oxygen (wt\%) & 2.1 & 2.3 & 2.3 & 2.31 \\
\hline Olefins (vol\%) & 8.4 & 7.9 & 9.7 & 10.4 \\
\hline Benzene (vol\%) & 0.7 & 0.9 & 0.9 & 0.9 \\
\hline $\begin{array}{l}\text { Sulfur (ppm by } \\
\text { weight) }\end{array}$ & 239 & 416 & 401 & 361 \\
\hline RVP (psi) & 12.5 & 11.9 & 11.9 & 11.9 \\
\hline
\end{tabular}

Sources: NPC (1993, Volume 5, Table F1-1A); ORNL (1994).

$\mathrm{HC}$ energy and crude oil input required to produce RFG with ETBE. This derivation is also explained.

\subsubsection{Greenhouse Gas Emissions Modeling}

The model used to develop the GHG coefficients for the various gasoline and oxygenate components was developed by Mark Delucchi ${ }^{25}$ to estimate the GHG emissions of alternative motor fuels (DeLuchi 1991, 1993; Delucchi 1993). Delucchi's model accounts for GHG emissions from vehicle operation, vehicle manufacture, fuel production and distribution, and feedstock recovery and transport (the transportation fuel cycle). The type and amount of energy used at each stage of the fuel cycle are accounted for, as are the type and amount of GHG emissions at each stage. Non- $\mathrm{CO}_{2}$ emissions are included and converted to a $\mathrm{CO}_{2}$-equivalent basis by using updated global warming potentials (GWPs) of greenhouse gases. (GWPs convert mass emissions of non- $\mathrm{CO}_{2}$ gases to the equivalent mass of $\mathrm{CO}_{2}$ over an assumed period of time.)

Although Delucchi's model was designed to estimate the GHG emissions of alternative motor fuels, it can also be used to derive estimates of GHG emissions from the various components of RFG. Delucchi provides estimates of the GHG emissions associated with ethanol, methanol, CG without oxygenates, and a base RFG oxygenated with MTBE. Several runs of his model were made in this analysis to provide GHG coefficients for ethanol, MTBE, ETBE, and HCs. GHG emissions associated with vehicle manufacture were deleted from all estimates.

25 Delucchi formerly spelled his name DeLuchi. 


\subsubsection{Normalization of Reformulated Gasolines to Deliver Equal Energy}

The per-gallon energy content of various RFGs is different for a number of reasons. Different volumes of different oxygenates are required to produce a given oxygen content. Moreover, the energy content of various oxygenates is different. In this analysis, an oxygen content of $2.1 \mathrm{wt} \%$ and one of $2.7 \mathrm{wt} \%$ are of interest. ANL developed a spreadsheet model that normalizes the various formulations of RFG (and CG) to the energy content of the "base RFG" (summer RFG oxygenated with MTBE to 2.1 wt\% oxygen). Once normalized, each fuel is capable of delivering the same VMT. For each fuel, the spreadsheet then calculates the energy, crude oil, and GHG emissions associated with delivering the same VMT as that delivered by the base RFG.

\subsubsection{Key Assumptions and Inputs}

Key assumptions and inputs for this analysis include the following:

- Gasolines were constrained to meet a $\mathrm{NO}_{\mathrm{x}}$ standard for the year 2000 with a cost effectiveness of about $\$ 10,000$ per (summer) ton of $\mathrm{NO}_{\mathrm{x}}$ reduced. This figure corresponds to an annual value of $\$ 5,000$ per ton of $\mathrm{NO}_{\mathrm{x}}$ reduced. This constraint resulted in gasolines that are close to complying with the Phase 2 RFG standards (standards issued after the model runs were completed). Additional $\mathrm{NO}_{\mathrm{x}}$ reduction would probably require additional hydrodesulfurization.

- All marginal changes in demand for isobutylene used to produce ether in merchant ether plants are derived from natural gas liquids (NGLs).

- Ethanol, methanol, and ether are produced as described in the sources cited in Section 3.4.

\subsection{VOLUME OF RFG REQUIRED TO DELIVER EQUAL ENERGY}

\subsubsection{Reformulated Gasoline with 2.1 wt\% Oxygen}

RFG can be made by using various oxygenates (MTBE, ETBE, ethanol, TAME, etc.). The energy content of each oxygenate differs. Moreover, the various oxygenates replace different volumes of gasoline to achieve the same oxygen level in the RFG. As a result, the type of oxygenate used and its volume fraction in the RFG affect the energy delivered (per gallon) for vehicle propulsion. Table 3.3 provides estimates of the per-gallon energy delivered by various RFGs oxygenated with MTBE, ETBE, and ethanol. (In the table, the estimates

assume Delucchi's base-case estimates of the energy and crude oil required to produce ethanol. See Section 3.4.3.) 
TABLE 3.3 Fuel Volume and Energy Content of RFG with 2.1 wt\% Oxygen and CG Based on Delucchi's Estimates of Energy and Crude Oil Required to Produce Ethanol ${ }^{\mathrm{a}}$

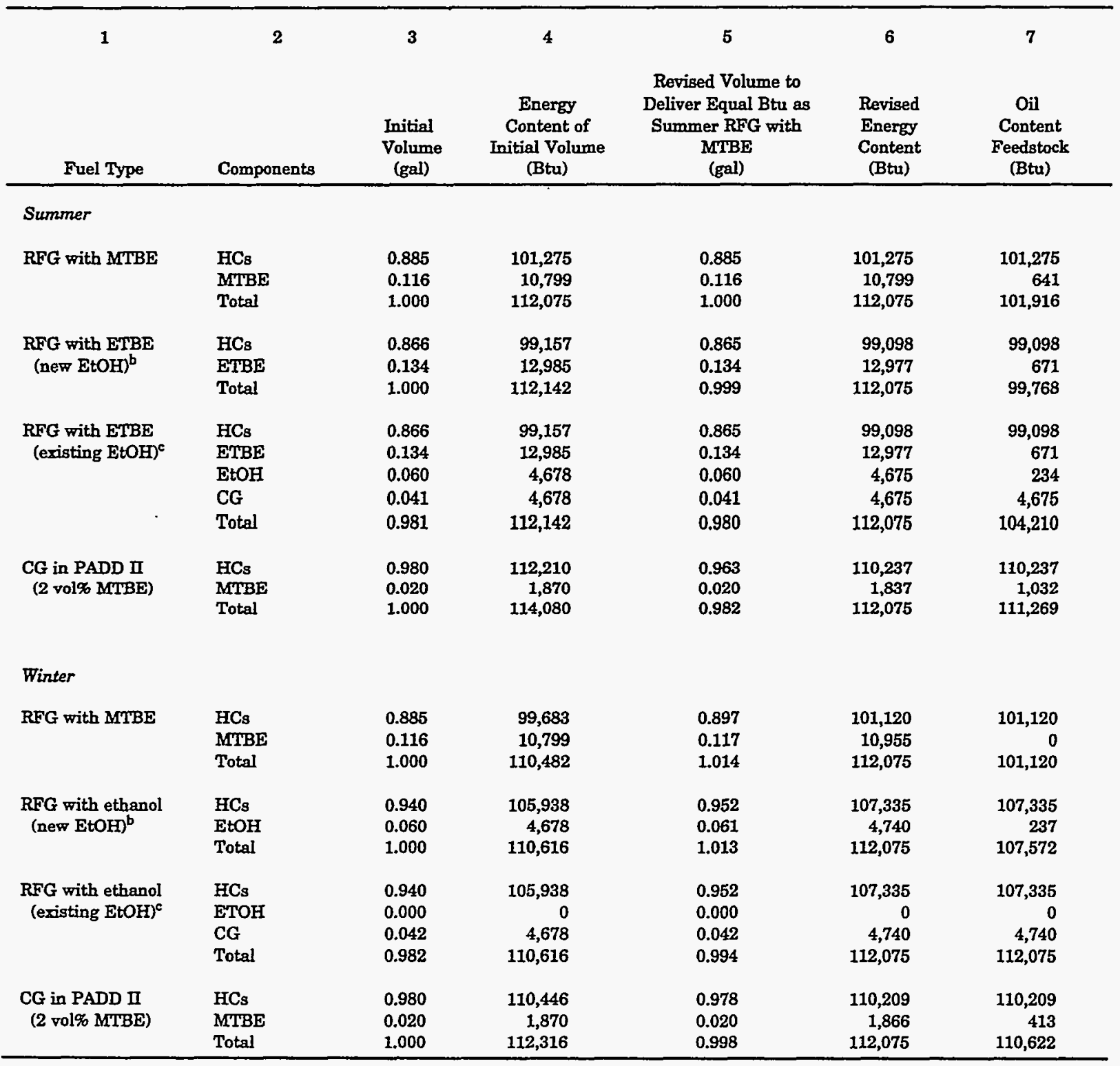


TABLE 3.3 (Cont.)

\begin{tabular}{|c|c|c|c|c|c|c|c|}
\hline 1 & $\begin{array}{c}2 \\
\text { Components }\end{array}$ & $\begin{array}{l}\text { Energy } \\
\text { Required to } \\
\text { Produce } \\
\text { RFG } \\
\text { (Btu) }\end{array}$ & $\begin{array}{l}\text { Oil } \\
\text { Required to } \\
\text { Produce } \\
\text { RFG } \\
\text { (Btu) }\end{array}$ & $\begin{array}{c}10 \\
\text { Total } \\
\text { Energy } \\
\text { Required } \\
\text { to Deliver } \\
\text { REG } \\
\text { (Btu) }\end{array}$ & $\begin{array}{c}11 \\
\text { Total } \\
\text { Fossil } \\
\text { Energy } \\
\text { Required } \\
\text { to Deliver } \\
\text { RFG } \\
\text { (Btu) }\end{array}$ & $\begin{array}{c}12 \\
\\
\text { Total } \\
\text { Oil } \\
\text { Required } \\
\text { to Deliver } \\
\text { RFG } \\
\text { (Btu) }\end{array}$ & $\begin{array}{c}\mathrm{CO}_{2-} \\
\text { Equivalent } \\
\text { Emissions (g) }\end{array}$ \\
\hline Summer & & & & & & & \\
\hline RFG with MTBE & $\begin{array}{l}\text { HCs } \\
\text { MTBE } \\
\text { Total }\end{array}$ & $\begin{array}{r}16,017 \\
3,216 \\
119,233\end{array}$ & $\begin{array}{r}9,072 \\
0 \\
9,072\end{array}$ & $\begin{array}{r}117,293 \\
14,015 \\
131,308\end{array}$ & $\begin{array}{r}117,293 \\
14,015 \\
131,308\end{array}$ & $\begin{array}{r}110,237 \\
641 \\
110,988\end{array}$ & $\begin{array}{r}10,749 \\
1,094 \\
11,844\end{array}$ \\
\hline $\begin{array}{l}\text { RFG with ETBE } \\
\text { (new EtOH) }\end{array}$ & $\begin{array}{l}\text { HCs } \\
\text { ETBE } \\
\text { Total }\end{array}$ & $\begin{array}{r}15,547 \\
6,156 \\
21,613\end{array}$ & $\begin{array}{r}8,661 \\
371 \\
9,032\end{array}$ & $\begin{array}{r}114,554 \\
19,133 \\
133,687\end{array}$ & $\begin{array}{r}114,554 \\
14,458 \\
129,012\end{array}$ & $\begin{array}{r}107,758 \\
1,042 \\
108,800\end{array}$ & $\begin{array}{r}10,479 \\
1,447 \\
11,926\end{array}$ \\
\hline $\begin{array}{l}\text { RFG with ETBE } \\
\text { (existing EtOH) }^{c}\end{array}$ & $\begin{array}{l}\text { HCs } \\
\text { EIBE } \\
\text { EtOH } \\
\text { CG } \\
\text { Total }\end{array}$ & $\begin{array}{r}15,457 \\
6,156 \\
4,114 \\
724 \\
18,222\end{array}$ & $\begin{array}{r}8,661 \\
371 \\
388 \\
550 \\
9,193\end{array}$ & $\begin{array}{r}114,554 \\
19,133 \\
8,790 \\
5,399 \\
130,297\end{array}$ & $\begin{array}{r}114,554 \\
14,458 \\
4,114 \\
5,399 \\
130,297\end{array}$ & $\begin{array}{r}107,758 \\
1,042 \\
622 \\
5,225 \\
113,403\end{array}$ & $\begin{array}{r}10,479 \\
1,447 \\
626 \\
493 \\
11,794\end{array}$ \\
\hline $\begin{array}{l}\text { CG in PADD II } \\
\text { ( } 2 \text { vol\% MTBE) }\end{array}$ & $\begin{array}{l}\text { HCs } \\
\text { MTBE } \\
\text { Total }\end{array}$ & $\begin{array}{r}17,069 \\
467 \\
17,537\end{array}$ & $\begin{array}{r}12,960 \\
0 \\
12,960\end{array}$ & $\begin{array}{r}127,306 \\
2,305 \\
129,611\end{array}$ & $\begin{array}{r}127,306 \\
2,305 \\
129,611\end{array}$ & $\begin{array}{r}123,197 \\
1,032 \\
124,229\end{array}$ & $\begin{array}{r}11,634 \\
186 \\
11,821\end{array}$ \\
\hline Winter & & & & & & & \\
\hline RFG with MTBE & $\begin{array}{l}\mathrm{HCs} \\
\text { MTBE } \\
\text { Total }\end{array}$ & $\begin{array}{r}13,481 \\
3,318 \\
16,799\end{array}$ & $\begin{array}{r}7,984 \\
0 \\
7,984\end{array}$ & $\begin{array}{r}114,601 \\
14,273 \\
128,874\end{array}$ & $\begin{array}{r}114,601 \\
14,273 \\
128,874\end{array}$ & $\begin{array}{r}109,104 \\
0 \\
109,104\end{array}$ & $\begin{array}{r}10,279 \\
1,110 \\
11,389\end{array}$ \\
\hline $\begin{array}{l}\text { RFG with ethanol } \\
\text { (new EtOH) }\end{array}$ & $\begin{array}{l}\mathrm{HCs} \\
\text { EtOH } \\
\text { Total }\end{array}$ & $\begin{array}{r}14,435 \\
4,171 \\
18,606\end{array}$ & $\begin{array}{r}8,656 \\
393 \\
9,050\end{array}$ & $\begin{array}{r}121,769 \\
8,911 \\
130,680\end{array}$ & $\begin{array}{r}121,769 \\
4,171 \\
125,940\end{array}$ & $\begin{array}{r}115,991 \\
630 \\
116,621\end{array}$ & $\begin{array}{r}10,933 \\
635 \\
11,568\end{array}$ \\
\hline $\begin{array}{l}\text { RFG with ethanol } \\
\text { (existing EtOH) }^{c}\end{array}$ & $\begin{array}{l}\mathrm{HCs} \\
\text { ETOH } \\
\text { CG } \\
\text { Total }\end{array}$ & $\begin{array}{r}14,435 \\
0 \\
668 \\
15,103\end{array}$ & $\begin{array}{r}8,656 \\
0 \\
487 \\
9,144\end{array}$ & $\begin{array}{r}121,769 \\
0 \\
5,408 \\
127,178\end{array}$ & $\begin{array}{r}121,769 \\
0 \\
5,408 \\
127,178\end{array}$ & $\begin{array}{r}115,991 \\
0 \\
5,227 \\
121,218\end{array}$ & $\begin{array}{r}10,933 \\
0 \\
488 \\
11,422\end{array}$ \\
\hline $\begin{array}{l}\text { CG in PADD II } \\
\text { (2 vol\% MTBE) }\end{array}$ & $\begin{array}{l}\text { HCs } \\
\text { MTBE } \\
\text { Total }\end{array}$ & $\begin{array}{r}15,537 \\
0 \\
16,330\end{array}$ & $\begin{array}{r}11,330 \\
0 \\
11,330\end{array}$ & $\begin{array}{r}125,746 \\
2,396 \\
128,141\end{array}$ & $\begin{array}{r}125,746 \\
2,396 \\
128,141\end{array}$ & $\begin{array}{r}121,538 \\
413 \\
121,952\end{array}$ & $\begin{array}{r}11,356 \\
189 \\
11,545\end{array}$ \\
\hline
\end{tabular}

a Energy, oil, and $\mathrm{CO}_{2}$-equivalent emissions for RFG volumes that contain the same energy as RFG with MTBE.

b New EtOH = incrementally produced ethanol as opposed to ethanol diverted from existing markets.

c Existing EtOH = ethanol diverted from existing markets. Ethanol has a zero value in the winter existing ethanol case because the ethanol used in RFG is exactly offset by ethanol that has been diverted. 
The RFGs in Table 3.3 are categorized as summer or winter fuels. Because of the VOC performance standard for summer RFG, and because ethanol is ineligible for ROS credit in the summer, only MTBE and ETBE are expected to be used to oxygenate RFG in the summer. Ethanol is quite likely to be used to oxygenate RFG in the winter and is therefore included in the winter fuel analysis section of the table.

Some of the estimates presented in Table 3.3 for RFG with ETBE and ethanol assume ethanol will be produced incrementally to the ethanol currently being produced in the United States (i.e., assume that additional ethanol beyond that currently being produced will be produced). This ethanol is henceforth called "new ethanol." Estimates of "existing ethanol" assume that the ethanol used in RFG (as either ethanol or ETBE) is diverted from current use. When ethanol is diverted, the net energy and crude oil effects related to ethanol production are zero, because the energy and crude oil savings that result from ending the production of ethanol for the original market are exactly offset by the energy and crude oil increases that result from producing ethanol for diversion to the new RFG market. However, the energy required to supply CG to replace ethanol in areas of the country from which it is diverted should be accounted for. Thus, the amount of CG that is sufficient to replace the ethanol energy in the RFG with ethanol or RFG with ETBE is included in the estimates of RFGs made with existing ethanol.

Column 2 of Table 3.3 lists the components of each gasoline that are of particular interest in this analysis: hydrocarbons, ethers, and ethanol. Column 3 presents the share of each of these components in a gallon of each gasoline type. This share is based on the volume of ether or ethanol required to meet the minimum $2.1 \mathrm{wt} \%$ oxygen content required of RFG; the source of these volume estimates is Table 3.4. Column 4 of Table 3.3 presents the energy content of a gallon of each gasoline type. The energy content is based on the share of each component in a gallon of gasoline (column 3) and the energy content (lower heating value) of each component, as presented in Table 3.5. Although the energy content of HCs used in RFGs varies slightly from one RFG to another, as demonstrated by the refinery LP runs, this analysis holds this energy content constant within each season. ${ }^{26}$

TABLE 3.4 Oxygen and Oxygenate Content of RFG

\begin{tabular}{cc}
$\begin{array}{c}\text { Oxygen Content } \\
\text { in RFG } \\
\text { (wt\%) }\end{array}$ & $\begin{array}{c}\text { Oxygenate } \\
\text { Content } \\
\text { ( vol\%) }\end{array}$ \\
\hline 2.1 & 13.4 ETBE \\
& $11.6 \mathrm{MTBE}$ \\
& 6.0 Ethanol \\
2.7 & 17.2 ETBE \\
& 15.0 MTBE \\
& 7.7 Ethanol \\
3.5 & 10.00 Ethanol \\
\hline
\end{tabular}

26 A sensitivity analysis was run to determine the effect of varying the summer fuel HC energy content. The effect was not significant with respect to the conclusions of the overall analysis reported here. 
RFGs are actually very similar in terms of the volume of fuel required to deliver the same energy when the source of the ethanol is new ethanol. As expected, because RFG has more oxygen and consequently a lower energy content than CG, a greater volume of $R F G$ is required.

\subsubsection{Reformulated Gasoline with 2.7 wt\% Oxygen}

Table 3.6 presents, for winter RFG with an oxygen content of $2.7 \mathrm{wt} \%$, estimates of the energy delivered by various RFGs and the volume required to deliver the same energy as that delivered by the base RFG. These winter RFGs will be used in areas that are $\mathrm{CO}$ nonattainment areas, generally a winter problem. This fuel will comply with both the federal RFG program standards and the federal OG program standards. Again, the fuel volumes presented in column 5 are the basis for the analysis in the remainder of this section.

\subsection{FEEDSTOCK REQUIREMENTS: CRUDE OIL CONTENT}

The crude oil content of RFGs varies because the volume of $\mathrm{HCs}$ in the different energy-equivalent RFGs varies and because the crude oil content of the oxygenates varies. Within this analysis, "crude oil content" means crude-oil-based material embodied in gasoline components (as feedstocks to the production process). Crude-oil-derived material consumed for energy in the production of fuel components, within or without refineries, is not considered crude oil content. ${ }^{27}$ Thus, isobutylene made from crude oil would have a crude oil content, but ethanol made from corn (before the addition of denaturant) would not, despite the fact that over the fuel cycle, crude-oil derivatives are consumed (as process energy) to produce corn and ethanol.

Estimates of the shares of various components of gasoline that are considered to be crude oil are presented in Table 3.7. Their derivation is described here. Pure ethanol and methanol have no crude oil content in the sense defined above. Ethanol is denatured for use in fuel and thus contains some gasoline or crude oil (an average value of $5 \mathrm{vol} \%$ is assumed) or another denaturant. The feedstock for the $\mathrm{HC}$ portion of gasoline is assumed to be $100 \%$ crude oil. In fact, some natural gas (as hydrogen) and some NGLs are used as feedstocks, and their proportion in the final fuel may vary across gasoline formulations. This potential shift

27 Crude oil consumed as process energy is tallied in column 9 ("Oil Required to Produce RFG") in Tables 3.3 and 3.6. The sum of "Oil Content (Feedstock)" (column 7) and column 9 is given in column 12 ("Total Oil Required to Deliver RFG"). 
TABLE 3.6 Fuel Volume and Energy Content of RFG with 2.7 wt\% Oxygen and CG Based on Delucchi's Estimates of Energy and Crude Oil Required to Produce Ethanol ${ }^{\mathrm{a}}$

\begin{tabular}{|c|c|c|c|c|c|c|c|}
\hline $\begin{array}{c}1 \\
\text { Fuel Type }\end{array}$ & $\begin{array}{c}2 \\
\text { Components }\end{array}$ & $\begin{array}{c}3 \\
\\
\\
\\
\text { Initial } \\
\text { Volume } \\
\text { (gal) }\end{array}$ & $\begin{array}{c}4 \\
\text { Energy } \\
\text { Content of } \\
\text { Initial } \\
\text { Volume } \\
\text { (Btu) }\end{array}$ & $\begin{array}{r}5 \\
\text { Revised Vo } \\
\text { Deliver } \mathrm{Eq} \\
\text { as Summ } \\
\text { at } 2.1 \mathrm{w} \\
\text { with } \mathrm{M} \\
\text { (gal }\end{array}$ & $\begin{array}{l}\text { ume to } \\
\text { tal } \mathrm{Btu} \\
\mathrm{RFG} \\
\mathrm{O}_{2} \\
\mathrm{BE}\end{array}$ & $\begin{array}{c}\text { Revised } \\
\text { Energy } \\
\text { Content } \\
\text { (Btu) }\end{array}$ & $\begin{array}{c}\text { Oil } \\
\text { Content } \\
\text { Feedstock } \\
\text { (Btu) }\end{array}$ \\
\hline RFG with MTBE & $\begin{array}{l}\text { HCs } \\
\text { MTBE } \\
\text { Total }\end{array}$ & $\begin{array}{l}0.852 \\
0.149 \\
1.000\end{array}$ & $\begin{array}{r}95,964 \\
13,855 \\
109,849\end{array}$ & $\begin{array}{l}0.869 \\
0.152 \\
1.020\end{array}$ & & $\begin{array}{r}97,908 \\
14,166 \\
112,075\end{array}$ & $\begin{array}{r}97,908 \\
0 \\
97,908\end{array}$ \\
\hline $\begin{array}{l}\text { RFG with ethanol } \\
\text { (new EtOH) }\end{array}$ & $\begin{array}{l}\mathrm{HCs} \\
\text { EIBE } \\
\text { Total }\end{array}$ & $\begin{array}{l}0.923 \\
0.077 \\
1.000\end{array}$ & $\begin{array}{r}104,045 \\
5,988 \\
110,033\end{array}$ & $\begin{array}{l}0.940 \\
0.078 \\
1.019\end{array}$ & & $\begin{array}{r}105,975 \\
6,099 \\
112,075\end{array}$ & $\begin{array}{r}105,975 \\
305 \\
106,280\end{array}$ \\
\hline $\begin{array}{l}\text { RFG with ethanol } \\
\text { (existing EtOF) }\end{array}$ & $\begin{array}{l}\text { HCs } \\
\text { EtOH } \\
\text { CG } \\
\text { Total }\end{array}$ & $\begin{array}{l}0.923 \\
0.000 \\
0.053 \\
0.976\end{array}$ & $\begin{array}{r}104,045 \\
0 \\
5,988 \\
110,033\end{array}$ & $\begin{array}{l}0.940 \\
0.000 \\
0.054 \\
0.994\end{array}$ & & $\begin{array}{r}105,975 \\
0 \\
6,099 \\
112,075\end{array}$ & $\begin{array}{r}105,975 \\
0 \\
6,099 \\
112,075\end{array}$ \\
\hline $\begin{array}{l}\text { CG in PADD II } \\
(2 \text { vol\% MTBE) }\end{array}$ & $\begin{array}{l}\mathrm{HCs} \\
\text { MTBE } \\
\text { Total }\end{array}$ & $\begin{array}{l}0.980 \\
0.020 \\
1.000\end{array}$ & $\begin{array}{r}110,446 \\
1,870 \\
112,316\end{array}$ & $\begin{array}{l}0.978 \\
0.020 \\
0.998\end{array}$ & & $\begin{array}{r}110,209 \\
1,866 \\
112,075\end{array}$ & $\begin{array}{r}110,209 \\
1,413 \\
110,622\end{array}$ \\
\hline 1 & Components & $\begin{array}{c}8 \\
\text { Energy } \\
\text { Required to } \\
\text { Produce } \\
\text { RFG } \\
\text { (Btu) }\end{array}$ & $\begin{array}{c}\text { Oil Required } \\
\text { to Produce } \\
\text { RFG } \\
\text { (Btu) }\end{array}$ & $\begin{array}{c}\text { Total Energy } \\
\text { Required to } \\
\text { Deliver RFG } \\
\text { (gal) }\end{array}$ & $\begin{array}{c}11 \\
\text { Total Fossil } \\
\text { Energy } \\
\text { Required to } \\
\text { Deliver } \\
\text { RFG } \\
\text { (Btu) }\end{array}$ & $\begin{array}{l}\text { Total Oil } \\
\text { Required } \\
\text { to Deliver } \\
\text { RFG } \\
\text { (Btu) }\end{array}$ & $\begin{array}{l}\mathrm{CO}_{2-} \\
\text { Equivalent } \\
\text { Emissions } \\
\text { (g) }\end{array}$ \\
\hline RFG with MTBE & $\begin{array}{l}\text { HCs } \\
\text { MTBE } \\
\text { Total }\end{array}$ & $\begin{array}{r}13,053 \\
4,291 \\
17,344\end{array}$ & $\begin{array}{r}7,730 \\
0 \\
7,730\end{array}$ & $\begin{array}{r}110,961 \\
18,457 \\
129,418\end{array}$ & $\begin{array}{r}110,961 \\
18,457 \\
129,418\end{array}$ & $\begin{array}{r}105,639 \\
0 \\
105,639\end{array}$ & $\begin{array}{r}9,953 \\
1,435 \\
11,388\end{array}$ \\
\hline $\begin{array}{l}\text { RFG with ethanol } \\
\text { (new EtOH) }\end{array}$ & $\begin{array}{l}\text { HCs } \\
\text { ETBE } \\
\text { Total }\end{array}$ & $\begin{array}{r}14,252 \\
5,367 \\
19,619\end{array}$ & $\begin{array}{r}8,547 \\
506 \\
9,053\end{array}$ & $\begin{array}{r}120,227 \\
11,467 \\
131,694\end{array}$ & $\begin{array}{r}120,227 \\
5,367 \\
125,595\end{array}$ & $\begin{array}{r}114,522 \\
811 \\
115,333\end{array}$ & $\begin{array}{r}10,795 \\
817 \\
11,612\end{array}$ \\
\hline $\begin{array}{l}\text { RFG with ethanol } \\
\text { (existing EtOH) }^{c}\end{array}$ & $\begin{array}{l}\text { HCs } \\
\text { EtOH } \\
\text { CG } \\
\text { Total }\end{array}$ & $\begin{array}{r}14,252 \\
0 \\
860 \\
15,112\end{array}$ & $\begin{array}{r}8,547 \\
0 \\
627 \\
9,174\end{array}$ & $\begin{array}{r}120,227 \\
0 \\
6,959 \\
127,186\end{array}$ & $\begin{array}{r}120,227 \\
0 \\
6,959 \\
127,186\end{array}$ & $\begin{array}{r}114,522 \\
0 \\
6,726 \\
121,248\end{array}$ & $\begin{array}{r}10,795 \\
0 \\
628 \\
11,423\end{array}$ \\
\hline $\begin{array}{l}\text { CG in PADD II } \\
(2 \text { vol\% M'TBE) }\end{array}$ & $\begin{array}{l}\text { HCs } \\
\text { MTBE } \\
\text { Total }\end{array}$ & $\begin{array}{r}15,537 \\
530 \\
16,067\end{array}$ & $\begin{array}{r}11,330 \\
0 \\
11,330\end{array}$ & $\begin{array}{r}127,746 \\
2,396 \\
128,141\end{array}$ & $\begin{array}{r}125,746 \\
2,396 \\
128,141\end{array}$ & $\begin{array}{r}121,538 \\
413 \\
121,952\end{array}$ & $\begin{array}{r}11,366 \\
189 \\
11,545\end{array}$ \\
\hline
\end{tabular}

a Energy, oil, and $\mathrm{CO}_{2}$-equivalent emissions for RFG volumes that contain the same energy as RFG with MTBE.

b New EtOH = incrementally produced ethanol as opposed to ethanol diverted from existing markets.

c Existing EtOH = ethanol diverted from existing markets. Ethanol has a zero value in the winter existing ethanol case because the ethanol used in RFG is exactly offset by ethanol that has been diverted 
TABLE 3.7 Crude Oil Content of Fuels (Oil Embodied in Fuels from Feedstocks)

\begin{tabular}{|c|c|c|c|c|c|}
\hline \multirow[b]{2}{*}{ Fuel Type } & \multirow{2}{*}{$\begin{array}{c}\text { Oil } \\
\text { Content } \\
(\%)\end{array}$} & \multicolumn{2}{|c|}{$\begin{array}{c}\text { Ether and Isobutylene } \\
\text { Production }\end{array}$} & \multicolumn{2}{|c|}{$\begin{array}{l}\text { Oil Feedstock } \\
\text { for Isobutylene }\end{array}$} \\
\hline & & $\begin{array}{c}\text { Internal } \\
\text { (share) }\end{array}$ & $\begin{array}{l}\text { External } \\
\text { (share) }\end{array}$ & $\begin{array}{l}\text { Internal } \\
\text { (share) }\end{array}$ & $\begin{array}{c}\text { External } \\
\text { (share) }\end{array}$ \\
\hline Feedstock ethanol (pure) & 0 & & & & \\
\hline Fuel ethanol (denatured) & 5 & & & & \\
\hline Methanol & 0 & & & & \\
\hline $\mathrm{HCs}$ & 100.0 & & & & \\
\hline \multicolumn{6}{|l|}{ Summer } \\
\hline \multicolumn{6}{|l|}{ Isobutylene } \\
\hline For ETBE in RFG & 7.5 & & & & \\
\hline $\begin{array}{l}\text { For MTBE only in RFG } \\
\text { For MTBE used with ethanol }\end{array}$ & 7.5 & 0.075 & 0.925 & 1 & 0 \\
\hline in RFG product mixes ${ }^{a}$ & 2.0 & 0.02 & 0.98 & 1 & 0 \\
\hline For MTBE in CG & 71.0 & 0.71 & 0.29 & 1 & 0 \\
\hline ETBE & 5.2 & & & & \\
\hline MTBE only in RFG & 5.9 & & & & \\
\hline \multicolumn{6}{|l|}{ MTBE used with ethanol in } \\
\hline RFG product mixes & 1.6 & & & & \\
\hline MTBE in CG & 56.2 & & & & \\
\hline \multicolumn{6}{|l|}{ Winter } \\
\hline \multicolumn{6}{|l|}{ Isobutylene } \\
\hline For MTBE only in RFG & 0 & 0 & 1 & 1 & 0 \\
\hline For MTBE in RFG/CG mix & 8.0 & 0.08 & 0.92 & 1 & 0 \\
\hline For MTBE in CG & 28.0 & 0.28 & 0.92 & 1 & 0 \\
\hline MTBE only in RFG & 0 & & & & \\
\hline MTBE in RFG/CG mix & 6.3 & & & & \\
\hline MTBE in CG & 22.1 & & & & \\
\hline
\end{tabular}

a "Product mixes" are mixed pools of fuels. Individual batches of differently oxygenated fuels are segregated (e.g., ether-oxygenated and ethanol-oxygenated RFGs are segregated).

in feedstock is not accounted for. The NGLs themselves can be made from crude oil, thereby complicating the analysis of such a shift.

The crude oil content of ETBE and MTBE reflects crude-oil-based isobutylene feedstock in ether production. Isobutylene may be produced from crude oil or from NGLs. This analysis assumes that all isobutylene produced outside the refinery and used to make ethers outside the refinery is derived from NGLs. These NGLs are assumed to be derived from natural-gas-related sources. Isobutylene produced within the refinery is assumed to be produced from crude oil.

The derivation of the proportion of isobutylene used within the refinery to produce ethers is based largely on estimates developed in NPC (1993). For that study, TM developed estimates of the materials that would be used to produce various gasolines, both conventional and reformulated. Table 3.8 gives several TM estimates of the raw materials that would be 
TABLE 3.8 Refinery Raw Materials and Products for Gasoline Used in PADD II in the Year 2000

\begin{tabular}{|c|c|c|c|c|c|c|c|}
\hline \multirow[b]{2}{*}{ Item } & \multicolumn{3}{|c|}{ Summer Gasolines } & \multicolumn{4}{|c|}{ Winter Gasolines } \\
\hline & $\begin{array}{c}\text { Base Case } \\
\text { (No CAAA) } \\
\text { (Case Q9) }\end{array}$ & $\begin{array}{l}\text { 100\% RFG } \\
\text { (MTBE only) } \\
\text { (Case S6) }\end{array}$ & $\begin{array}{c}100 \% \text { RFG } \\
\text { (30\% EtOH) } \\
\text { (Case S13H) }\end{array}$ & $\begin{array}{l}\text { Base Case } \\
\text { (No CAAA) } \\
\text { (Case Q9W) }\end{array}$ & $\begin{array}{l}\text { 65\% RFG/Rest CG } \\
\text { (MTBE only) } \\
\text { (Case Q6W) }\end{array}$ & $\begin{array}{l}\text { 62\% RFG/Rest CG } \\
\text { (MTBE only) } \\
\text { (PADD III) }\end{array}$ & $\begin{array}{l}\text { 62\% RFG/Rest CG } \\
\text { (30\% EtOH) } \\
\text { (PADD III) }\end{array}$ \\
\hline \multicolumn{8}{|l|}{ Products (bbl/d) } \\
\hline Gasoline & $1.682 \mathrm{E}+06$ & $1.713 \mathrm{E}+06$ & $1.717 \mathrm{E}+06$ & $1.659 \mathrm{E}+06$ & $1.681 \mathrm{E}+06$ & $3.093 E+06$ & $3.092 \mathrm{E}+06$ \\
\hline (\% ether or ethanol) & 2 & 12 & 10 & 2 & 8 & 8 & 7 \\
\hline Diesel & $6.820 \mathrm{E}+05$ & $6.820 \mathrm{E}+05$ & $6.820 \mathrm{E}+06$ & $6.820 \mathrm{E}+05$ & $6.820 \mathrm{E}+05$ & $1.324 \mathrm{E}+06$ & $1.324 \mathrm{E}+06$ \\
\hline Jet fuel & $2.050 \mathrm{E}+05$ & $2.050 \mathrm{E}+05$ & $2.050 \mathrm{E}+05$ & $2.130 \mathrm{E}+05$ & $2.130 \mathrm{E}+05$ & $7.704 \mathrm{E}+05$ & $7.704 \mathrm{E}+05$ \\
\hline Subtotal & $2.669 \mathrm{E}+06$ & $2.600 \mathrm{E}+06$ & $2.604 \mathrm{E}+06$ & $2.554 \mathrm{E}+06$ & $2.576 \mathrm{E}+06$ & $6.187 \mathrm{E}+06$ & $6.187 \mathrm{E}+08$ \\
\hline Plant fuel burned & $2.306 \mathrm{E}+05$ & $1.856 \mathrm{E}+05$ & $2.007 \mathrm{E}+05$ & $1.973 \mathrm{E}+05$ & $1.769 \mathrm{E}+05$ & $4.947 E+05$ & $5.019 \mathrm{E}+05$ \\
\hline Other & $3.620 \mathrm{E}+05$ & $3.775 \mathrm{E}+05$ & $4.293 E+05$ & $2.624 \mathrm{E}+05$ & $2.540 \mathrm{E}+05$ & $1.071 \mathrm{E}+06$ & $1.041 \mathrm{E}+08$ \\
\hline Total & $3.162 \mathrm{E}+06$ & $3.163 \mathrm{E}+06$ & $3.234 \mathrm{E}+06$ & $3.013 \mathrm{E}+06$ & $3.007 E+06$ & $6.752 \mathrm{E}+06$ & $6.730 \mathrm{E}+06$ \\
\hline \multicolumn{8}{|l|}{ Production fuels } \\
\hline Plant fuel burned (bbl/d) & $2.306 \mathrm{E}+05$ & $1.856 \mathrm{E}+05$ & $2.007 \mathrm{E}+05$ & $1.873 \mathrm{E}+05$ & $1.769 \mathrm{E}+05$ & $4.947 E+05$ & $5.019 E+05$ \\
\hline Natural gas purchased (FOE) & $3.290 \mathrm{E}+04$ & $6.820 \mathrm{E}+04$ & $7.090 \mathrm{E}+04$ & $3.790 \mathrm{E}+04$ & $4.710 \mathrm{E}+04$ & $1.640 \mathrm{E}+05$ & $1.640 \mathrm{E}+05$ \\
\hline Electricity $(\mathrm{kWh} / \mathrm{d})$ & $2.490 \mathrm{E}+07$ & $2.330 \mathrm{E}+07$ & $2.690 E+07$ & $2.190 \mathrm{E}+07$ & $2.120 \mathrm{E}+07$ & $0^{d}$ & $0^{d}$ \\
\hline Electricity FOE & $4.021 \mathrm{E}+04$ & $3.763 \mathrm{E}+04$ & $4.183 E+04$ & $3.637 \mathrm{E}+04$ & $3.424 \mathrm{E}+04$ & 0 & 0 \\
\hline \multicolumn{8}{|l|}{ Raw materials for MTBE } \\
\hline MTBE & $1.000 \mathrm{E}+04$ & $1.840 \mathrm{E}+05$ & $1.390 \mathrm{E}+05$ & $2.400 \mathrm{E}+04$ & $1.166 \mathrm{E}+05$ & $1.961 \mathrm{E}+05$ & $1.254 \mathrm{E}+05$ \\
\hline Methanol & $8.000 \mathrm{E}+03$ & $5.000 \mathrm{E}+03$ & $1.000 \mathrm{E}+03$ & $3.200 \mathrm{E}+03$ & $3.200 \mathrm{E}+03$ & $1.620 \mathrm{E}+04$ & $1.630 \mathrm{E}+04$ \\
\hline Total MTBE used & $3.400 \mathrm{E}+04$ & $1.990 \mathrm{E}+05$ & $1.420 \mathrm{E}+05$ & $3.360 \mathrm{E}+04$ & $1.262 \mathrm{E}+05$ & $2.447 \mathrm{E}+05$ & $1.713 \mathrm{E}+05$ \\
\hline
\end{tabular}

a Several results are presented for PADD III.

b $\mathrm{CAAA}=$ Clean Air Act Amendments.

c FOE $=$ fuel oil equivalent.

d There is electric power use in these cases, but electricity is generated on the refinery site, and the associated energy requirement is accounted for in the row labeled "Plant fuel burned." Sources: Turner, Mason \& Company for NPC (1993); Lax (1994); Hadder (1994); unpublished information. 
used in the refinery to produce the MTBE needed for RFG and CG production. When MTBE is listed as a raw material, the assumption is that the MTBE (including its isobutylene feedstock) is produced outside the refinery. When methanol is listed as a raw material, the assumption is that crude-oil-based isobutylene (made within the refinery) is reacted with methanol to produce MTBE. Table 3.8 presents data on both summer and winter RFG. (The background data upon which this table is based are provided in Appendix C.)

For the base RFG (summer RFG oxygenated with 100\% MTBE), it is estimated that 7.5\% of the ethers would be produced within the refinery. For the summer RFG in which 70\% is produced with MTBE and 30\% is produced with ethanol, the TM estimates suggest that just $2 \%$ of the ether and isobutylene would be produced within refineries.

The estimated levels of internal ether production may appear low, but they are consistent with other process changes within the refinery related to the production of severely reformulated gasoline. Most important is the demand for C-4 olefins as feedstocks to the alkylation process; these olefins might otherwise be used for ether production. As the HC portion of the RFG is more severely reformulated to achieve additional VOC reductions to offset the higher RVP of ethanol-blended RFG, the refinery shifts further away from internal ether production.

No separate runs were performed by TM for RFG oxygenated with ETBE. This analysis assumes that the crude oil feedstock for the isobutylene used to produce ETBE is the same as that for the isobutylene used to produce MTBE. Because the alcohols used to make ETBE and MTBE differ, the fractions of crude oil in the ethers differ, as shown in Table 3.7.

TM provided two winter gasoline runs, but none with $100 \% \mathrm{RFG}$ production. On the basis of the material presented in Table 3.8 for the two runs (Case Q9W and Case Q6W), Table 3.7 estimates that $28 \%$ of the MTBE produced for use in CG will be produced internally and $8 \%$ of the MTBE produced for an RFG/CG product mix of about 50-50 will also be produced internally. In terms of the volumes of methanol used as a raw material in gasoline production, the TM runs indicate that no additional methanol is used to produce the RFG/CG mix beyond the amount used for $100 \%$ CG production. Therefore, since the production of RFG did not increase the amount of MTBE produced internally, it is assumed that all the internal production of MTBE for the RFG/CG mix is assigned to CG and all the MTBE produced for RFG is produced externally. (As shown in Table 3.7, the MTBE used in winter RFG is estimated to contain no crude oil).

Results of two additional winter gasoline simulations are provided in Table 3.8. The simulations were developed to assess the amount of energy and materials required to produce winter RFG with ethanol. TM did not provide such an assessment; therefore, ORNL used its refinery model and PADD III data to provide the simulations. The results of these two runs were not used directly to analyze crude oil content, but an examination of the runs indicates that they, too, support estimates that significant amounts of the MTBE to be used in RFG are produced externally. 
In column 7 of Tables 3.3 and 3.6, the crude oil content percentages derived in Table 3.7 are applied to all components of each RFG to develop a total estimate of the crude oil feedstock in each RFG. The tables reflect seasonal differences in crude oil content (for comparable fuels, winter is lower) and the fact that the crude oil content of RFG with MTBE is lower than that of $\mathrm{CG}$.

When new ethanol is used, RFG oxygenated with ETBE uses less crude oil than the base RFG; RFG oxygenated with ethanol uses more. ${ }^{28}$ Diversion of ethanol from current use causes both RFG with ETBE and RFG with ethanol to have a higher crude oil content than the base RFG. This result occurs because CG is substituted for the ethanol that has been diverted for use in $\mathrm{RFG}^{29}$

\subsection{PROCESS ENERGY REQUIREMENTS}

Estimates of the energy and crude oil required to produce the components of the various gasolines were derived from several sources. This section first addresses the production of the individual components and then discusses the total energy required to produce the final fuels.

\subsubsection{Energy and Crude Oil Required to Produce Hydrocarbons}

\subsubsection{Hydrocarbons for Summer Fuels}

As indicated, TM refinery LP model runs and two ORNL runs were used to determine the amount of energy and materials that would be required to produce various fuels. Table 3.8 summarizes the TM and ORNL results. These estimates were used to determine the amount of energy (plant fuel, natural gas, and electricity) and crude oil (plant fuel) required to produce the HCs used in RFG and CG.

28 About $13.4 \%$ of the volume of $\mathrm{HCs}$ is replaced by ETBE at the $2.1 \mathrm{wt} \%$ oxygen level; MTBE replaces about $11.6 \%$ of $\mathrm{HCs}$ for the same oxygen content. Isobutylene feedstock for ether production is assumed to be $92.5 \%$ from natural gas sources and $7.5 \%$ from crude oil; feedstock ethanol and methanol contain no oil (ethanol feedstock is not denatured). On the basis of these assumptions, a larger amount of crude oil is probably replaced by ETBE than by MTBE.

When used as an oxygenate (rather than as a feedstock), ethanol replaces a smaller volume of HCs (6\%) than does MTBE, and it contains a bit of crude oil in the denaturant. On the basis of these assumptions, ethanol-oxygenated RFG probably contains more crude oil than MTBE-oxygenated RFG. The relative crude oil content of these fuels appears in column 7 of Table 3.3.

29 In the existing-ethanol cases, the crude oil content of the CG that replaces the ethanol diverted from CG to RFG is attributed to the oil content of RFG in column 7 of Table 3.3. The crude oil content of the diverted ethanol is deducted from the oil content of RFG but is much less than the crude oil from CG that replaces it. 
The analysis of the energy and crude oil required to produce HCs assumes that all the plant fuel, natural gas, and electricity used in the refinery are used to produce the HCs for motor gasoline, diesel fuels, and jet fuel. These three fuels represent more than $75 \%$ of the products of the refinery. The diesel and jet fuel product volumes are then held constant over the various RFG and CG runs. All the runs result in the production of equal amounts of gasoline energy for vehicular propulsion. Any differences in the energy and crude oil required per gallon of $\mathrm{HC}$ produced are attributed to the different processing requirements of the various RFGs. The results of the analysis of the summer fuel runs are presented in Table 3.9. Some very small shifts in other products occurred, but these are not accounted for in this analysis.

As indicated in Table 3.9 and summarized in Table 3.10, little difference is estimated between the amount of energy required to produce HCs for summer RFG with MTBE and that required to produce them for CG, although less crude oil is required to produce the HCs used in RFG. The energy required to produce HCs for mixed RFG pool is greater than that required to produce them for RFG with MTBE only, because the HCs must be more severely processed to achieve the incremental VOC reductions needed to offset the VOC increase associated with ethanol use. Ethanol has a higher blending RVP than MTBE, which, if no other adjustments are made, increases the VOC level of the final fuel. Additional processing of the HC components is required to achieve a lower RVP level and maintain the same overall VOC level.

No refinery LP model runs for summer RFG with any ETBE mix were made. However, the use of ETBE in RFG should allow the refiner to use higher-RVP HCs (approximately 0.5 higher RVP), because ETBE has a substantially lower blending RVP than does MTBE. Use of these higher-RVP HCs should, at a minimum, lower plant fuel requirements below those for RFG with MTBE, because the lighter (higher-RVP) components can be used and additional processing to obtain lower-RVP components is not required.

An estimate of the amount of energy required to produce HCs for RFG with ETBE was derived by examining TM estimates of the energy required to produce two RFGs with a 0.4 RVP delta in their gasoline pool properties. The RVPs of the gasolines examined are 7.2 and 6.8. The amount of energy required to produce these RVPs may be greater than would actually be needed, but this situation is not relevant for this analysis, in which the focus is on the difference between the energy requirements of the two RFGs. Use of a 0.4 RVP delta rather than 0.5 RVP slightly understates this potential benefit of the use of ETBE. The TM runs examined were Case VLQ40 (V. Low $\triangle$ VOC) and Case LQ40 (Low $\Delta$ VOC); see Appendix C. PADD III runs were used in this analysis because similar runs were not made for PADD II.

This analysis estimates that an additional 250 Btu per gallon of $\mathrm{HC}$ produced is required to achieve the lower RVP. When this estimate is applied to the estimates of energy and crude oil required to produce $\mathrm{HCs}$ for summer RFG with MTBE, estimates of the energy and crude oil required to produce HCs for summer RFG with ETBE can be derived. These latter estimates are shown in Table 3.10. 
TABLE 3.9 Plant Fuel Burned and Fuels Purchased to Produce HCs: Summer Gasolines (LP Runs Only)

\begin{tabular}{|c|c|c|c|}
\hline Item & $\begin{array}{l}\text { Base Case } \\
\text { (No CAAA) } \\
\text { (Case Q9) }^{\mathrm{a}}\end{array}$ & $\begin{array}{c}100 \% \text { RFG } \\
\text { (MTBE only) } \\
\text { (Case S6) }\end{array}$ & $\begin{array}{c}100 \% \mathrm{RFG} \\
\text { (30\% EtOH) } \\
\text { (Case S13H) }\end{array}$ \\
\hline \multicolumn{4}{|l|}{ HCs produced } \\
\hline Total HCs (bbl/d) & $2.535 \mathrm{E}+06$ & $2.400 \mathrm{E}+06$ & $2.434 \mathrm{E}+06$ \\
\hline Total HCs (gal) & $1.065 \mathrm{E}+08$ & $1.008 \mathrm{E}+08$ & $1.022 \mathrm{E}+08$ \\
\hline Diesel/jet only (bbl/d) & $8.870 \mathrm{E}+05$ & $8.870 \mathrm{E}+05$ & $8.870 \mathrm{E}+05$ \\
\hline Diesel/jet only (gal) & $3.725 \mathrm{E}+07$ & $3.725 \mathrm{E}+07$ & $3.725 \mathrm{E}+07$ \\
\hline Gasoline only (bbl/d) & $1.648 \mathrm{E}+06$ & $1.513 \mathrm{E}+06$ & $1.547 \mathrm{E}+06$ \\
\hline Gasoline only (gal) & $6.923 \mathrm{E}+07$ & $6.353 \mathrm{E}+07$ & $6.497 \mathrm{E}+07$ \\
\hline \multicolumn{4}{|l|}{$\begin{array}{l}\text { Total energy in plant fuel burned } \\
\text { to produce HCs }\end{array}$} \\
\hline Total HCs (Btu) & $1.433 \mathrm{E}+12$ & $1.153 \mathrm{E}+12$ & $1.248 \mathrm{E}+12$ \\
\hline Diesel/jet only (Btu) ${ }^{b}$ & $5.015 \mathrm{E}+11$ & $5.015 \mathrm{E}+11$ & $5.015 \mathrm{E}+11$ \\
\hline Gasoline only (Btu) & $9.319 \mathrm{E}+11$ & $6.516 \mathrm{E}+11$ & $7.461 \mathrm{E}+11$ \\
\hline \multicolumn{4}{|l|}{$\begin{array}{l}\text { Energy in plant fuel burned } \\
\text { to produce HCs }\end{array}$} \\
\hline Total HCs (Btu/gal produced) & $1.346 \mathrm{E}+04^{\mathrm{c}}$ & & \\
\hline Diesel/jet only (Btu/gal produced) ${ }^{b}$ & $1.346 \mathrm{E}+04^{\mathrm{c}}$ & $1.346 \mathrm{E}+04$ & $1.346 \mathrm{E}+04$ \\
\hline Gasoline only (Btu/gal produced) & $1.346 \mathrm{E}+04^{\mathrm{c}}$ & $1.026 \mathrm{E}+04$ & $1.148 \mathrm{E}+04$ \\
\hline Gasoline only (Btu/Btu HC produced) & 0.118 & 0.009 & 0.100 \\
\hline \multicolumn{4}{|l|}{$\begin{array}{l}\text { Total energy in plant fuel burned, } \\
\text { natural gas, and electricity to produce HCs }\end{array}$} \\
\hline Total HCs (Btu) & $1.888 \mathrm{E}+12$ & $1.811 \mathrm{E}+12$ & $1.948 \mathrm{E}+12$ \\
\hline Diesel/jet only (Btu) ${ }^{b}$ & $6.605 \mathrm{E}+11$ & $6.605 \mathrm{E}+11$ & $6.605 \mathrm{E}+11$ \\
\hline Gasoline only (Btu) & $1.227 \mathrm{E}+12$ & $1.150 \mathrm{E}+12$ & $1.288 \mathrm{E}+12$ \\
\hline \multicolumn{4}{|l|}{$\begin{array}{l}\text { Energy in plant fuel burned, } \\
\text { natural gas, and electricity to produce HCs }\end{array}$} \\
\hline Total HCs (Btu/gal produced) & $1.773 \mathrm{E}+04^{\mathrm{c}}$ & & \\
\hline Diesel/jet only (Btu/gal produced) ${ }^{b}$ & $1.773 \mathrm{E}+04^{\mathrm{c}}$ & $1.773 \mathrm{E}+04$ & $1.773 \mathrm{E}+04$ \\
\hline Gasoline only (Btu/gal produced) & $1.773 \mathrm{E}+04^{\mathrm{c}}$ & $1.811 \mathrm{E}+04$ & $1.982 \mathrm{E}+04$ \\
\hline Gasoline only (Btu/Btu HC produced) & 0.155 & 0.158 & 0.173 \\
\hline
\end{tabular}

a CAAA = Clean Air Act Amendments.

b Energy in plant fuel burned, natural gas, and electricity to produce diesel and jet fuel is held constant across runs.

c Energy in plant fuel burned, natural gas, and electricity to produce HCs in conventional gasoline is assumed to be the same for gasoline and diesel and jet fuel. 
TABLE 3.10 Plant Fuel Burned and Fuels Purchased to Produce HCs: Summary

\begin{tabular}{lcc}
\hline \multicolumn{1}{c}{ Fuels } & $\begin{array}{c}\text { Energy in Plant Fuel } \\
\text { Burned, Natural Gas, and } \\
\text { Electricity to Produce HCs } \\
\text { (Btu/Btu HC Produced) }\end{array}$ & $\begin{array}{c}\text { Energy in Plant Fuel } \\
\text { Burned to Produce HCs } \\
\text { (Btu/Btu HC Produced) }\end{array}$ \\
\hline Summer & & \\
CG & 0.155 & 0.118 \\
RFG with MTBE only & 0.158 & 0.090 \\
RFG with MTBE and EtOH & 0.173 & 0.100 \\
RFG with ETBE only & 0.156 & 0.087 \\
Winter & & \\
CG & 0.141 & 0.103 \\
RFG/CG mix with MTBE & 0.137 & 0.090 \\
RFG with MTBE only & 0.133 & 0.079 \\
RFG with EtOH only & 0.134 & 0.081 \\
\hline
\end{tabular}

\subsubsection{Hydrocarbons for Winter Fuels}

The analysis of the energy and crude oil required to produce HCs for winter RFGs is based on the same general assumptions as those used for the summer fuel analysis, with some minor differences. Table 3.11 presents the analysis of the winter fuel runs. No winter runs resulted in $100 \%$ RFG. Therefore, to estimate the amount of energy and crude oil required to produce the HCs for RFG oxygenated with MTBE, the per-gallon energy required to produce HCs for CG was held constant between the all-CG case (TM case Q9W) and the RFG/CG-mix case (TM case Q6W). The result is that the amount of energy and crude oil required to produce HCs for winter RFG oxygenated with MTBE is lower than the amount required to produce $\mathrm{HCs}$ for winter $\mathrm{CG}$.

To determine the energy and crude oil required to produce HCs for winter RFG oxygenated with ethanol, the results of the two ORNL refinery model runs were used. One run simulated production of a RFG/CG mix in which the RFG was oxygenated with MTBE only. Another run simulated the same RFG/CG mix, but with $30 \%$ of the RFG oxygenated with ethanol. A delta between the energy required to produce the HCs for the two mixes was derived and assigned to the energy required to produce HC for RFG oxygenated with ethanol only. This delta is extremely small. However, it was added to the estimates derived from the TM runs for the energy required to produce winter HCs for RFG with MTBE only. Estimates of the total energy required to produce HCs for RFG with ethanol resulted.

Table 3.10 presents summary estimates of the amount of energy and crude oil required to produce HCs for use in RFGs and CG. It shows that more total energy is required to produce HCs used in summer RFGs than to produce HCs used in CG. Less energy is required to produce $\mathrm{HCs}$ used in winter RFG, however. The amount of crude oil required 
TABLE 3.11 Plant Fuel Burned and Fuels Purchased to Produce HCs: Winter Gasolines (LP Runs Only)

\begin{tabular}{|c|c|c|c|c|c|c|c|}
\hline Item & $\begin{array}{c}\text { Base Case } \\
(\text { No CAAA) } \\
(\text { Case QgW) }\end{array}$ & $\begin{array}{c}\text { 65\% RFG/Rest CG } \\
\text { (MTBE only) } \\
\text { (Case Q6W) }\end{array}$ & $\begin{array}{l}\text { RFG-MTBE } \\
\text { Only } \\
\text { (No case) }\end{array}$ & $\begin{array}{l}\text { 62\% RFG/Rest CG } \\
\text { (MTBE only) } \\
\text { (PADD III) }\end{array}$ & $\begin{array}{l}\text { 62\% RFG/Rest CG } \\
\text { (30\% EtOH) } \\
\text { (PADD III) }\end{array}$ & $\begin{array}{l}\text { Delta for } \\
\text { RFG-EtoH } \\
\text { Only }\end{array}$ & $\begin{array}{l}\text { RFG-EtOH } \\
\text { Only } \\
\text { (No case) }\end{array}$ \\
\hline \multicolumn{8}{|l|}{ HCs produced } \\
\hline Total HCs (bbl/d) & $2.620 \mathrm{E}+06$ & $2.450 \mathrm{E}+06$ & & $4.942 \mathrm{E}+06$ & $4.977 \mathrm{E}+06$ & & \\
\hline Total HCs (gal) & $1.069 \mathrm{E}+08$ & $1.029 \mathrm{E}+08$ & & $2.076 \mathrm{E}+08$ & $2.090 \mathrm{E}+08$ & & \\
\hline Diesel/jet only (bbl/d) & $8.950 \mathrm{E}+05$ & $8.950 \mathrm{E}+05$ & & $2.095 \mathrm{E}+06$ & $2.095 E+06$ & & \\
\hline Dieseljjet (gal) & $3.759 \mathrm{E}+07$ & $3.759 \mathrm{E}+07$ & & $8.797 E+07$ & $8.797 \mathrm{E}+07$ & & \\
\hline Gasoline only (bbl/d) & $1.625 \mathrm{E}+06$ & $1.555 \mathrm{E}+06$ & & $2.848 \mathrm{E}+06$ & $2.883 \mathrm{E}+06$ & & \\
\hline Gasoline only (gal) & $6.826 \mathrm{E}+07$ & $6.531 \mathrm{E}+07$ & & $1.196 \mathrm{E}+08$ & $1.211 \mathrm{E}+08$ & & \\
\hline $\mathrm{CG}$ only $(\mathrm{bbl} / \mathrm{d})$ & $1.625 \mathrm{E}+06$ & $7.346 \mathrm{E}+05$ & & & & & \\
\hline CG only (gal) & $6.826 \mathrm{E}+07$ & $3.085 E+07$ & & & & & \\
\hline RFG only (bbl/d) & & $8.205 \mathrm{E}+05$ & & & & & \\
\hline RFG only (gal) & & $3.446 \mathrm{E}+07$ & & & & & \\
\hline \multicolumn{8}{|c|}{ Total energy in plant fuel burned to produce $\mathrm{HCs}_{\mathrm{s}}$} \\
\hline Total HCs (Btu) & $1.226 \mathrm{E}+12$ & $1.100 \mathrm{E}+12$ & & $3.075 \mathrm{E}+12$ & $3.120 \mathrm{E}+12$ & & \\
\hline Diesel/jet only (Btu) ${ }^{b}$ & $4.365 \mathrm{E}+11$ & $4.355 \mathrm{E}+11$ & & $1.303 \mathrm{E}+12$ & $1.303 \mathrm{E}+12$ & & \\
\hline Gasoline only (Btu) & $7.909 \mathrm{E}+11$ & $6.641 \mathrm{E}+11$ & & $1.772 \mathrm{E}+12$ & $1.817 \mathrm{E}+12$ & & \\
\hline CG only (Btu) & & $3.575 \mathrm{E}+11$ & & & & & \\
\hline RFG only (Btu) & & $3.066 \mathrm{E}+11$ & & & & & \\
\hline \multicolumn{8}{|c|}{ Energy in plant fuel burned to produce $\mathrm{HCs}$} \\
\hline Total HCs (Btu/gal produced) & $1.169 E+04^{c}$ & & & $1.481 \mathrm{E}+04$ & & & \\
\hline Diesel/jet only (Btu/gal produced) $)^{b}$ & $1.159 \mathrm{E}+04^{\mathrm{c}}$ & $1.169 \mathrm{E}+04$ & & $1.481 \mathrm{E}+04$ & $1.481 E+04$ & & \\
\hline Gasoline only (Btu/gal produced) & $1.159 \mathrm{E}+04^{\mathrm{c}}$ & $1.017 \mathrm{E}+04$ & & $1.481 \mathrm{E}+04$ & $1.500 \mathrm{E}+04$ & & \\
\hline Gasoline only (Btu/Btu HC produced) & 0.103 & 0.090 & & 0.131 & 0.133 & 0.002 & \\
\hline CG only (Btu/gal produced) & $1.159 \mathrm{E}+04^{\mathrm{c}}$ & $1.169 \mathrm{E}+04$ & & & & & \\
\hline CG only (Btu/Btu HC produced) & & 0.103 & & & & & \\
\hline RFG only (Btu/gal produced) & & $8.898 \mathrm{E}+03$ & & & & & \\
\hline RFG only (Btu/Btu HC produced) & & 0.079 & 0.079 & & & 0.002 & 0.81 \\
\hline \multicolumn{8}{|c|}{ Total energy in plant fuel burned, natural gas, and electricity to produce $\mathrm{HCg}$} \\
\hline Total HCa (Btu) & $1.682 \mathrm{E}+12$ & $1.605 \mathrm{E}+12$ & & $4.094 \mathrm{E}+12$ & $4.139 \mathrm{E}+12$ & & \\
\hline Diesel/jet only (Btu) ${ }^{b}$ & $5.972 \mathrm{E}+11$ & $6.972 E+11$ & & $1.735 \mathrm{E}+12$ & $1.795 \mathrm{E}+12$ & & \\
\hline Gasoline only (Btu) & $1.085 \mathrm{E}+12$ & $1.008 \mathrm{E}+12$ & & & & & \\
\hline CG only (Btu) & & $4.902 \mathrm{E}+11$ & & & & & \\
\hline RFG only (Btu) & & $5.177 \mathrm{E}+11$ & & & & & \\
\hline
\end{tabular}




\section{TABLE 3.11 (Cont.)}

\begin{tabular}{|c|c|c|c|c|c|c|c|}
\hline Items & $\begin{array}{c}\text { Base Case } \\
\text { (No CAAA) } \\
\text { (Case Q9W) }\end{array}$ & $\begin{array}{l}\text { 55\% RFG/Rest CG } \\
\text { (MTBE only) } \\
\text { (Case Q6W) }\end{array}$ & $\begin{array}{l}\text { RFG-MTBEE } \\
\text { Only } \\
\text { (No case) }\end{array}$ & $\begin{array}{c}\text { 62\% RFG/Rest CG } \\
\text { (MTBE only) } \\
\text { (PADD III) }\end{array}$ & $\begin{array}{l}\text { 62\% RFG/Rest CG } \\
\text { (30\% EtOH) } \\
\text { (PADD III) }\end{array}$ & $\begin{array}{l}\text { Delta for } \\
\text { RFG-EtOH } \\
\text { Only }\end{array}$ & $\begin{array}{l}\text { RFG-EtOH } \\
\text { Only } \\
\text { (No case) }\end{array}$ \\
\hline \multicolumn{8}{|c|}{ Energy in plant fuel burned, natural gas, and electricity to produce $\mathrm{HC} s$} \\
\hline Total HCs (Btu/gal produced) & $1.589 \mathrm{E}+04^{\mathrm{c}}$ & & & $1.972 \mathrm{E}+04$ & & & \\
\hline Diesel/jet only (Btu/gal produced) & $1.689 \mathrm{E}+04^{\mathrm{c}}$ & $1.589 \mathrm{E}+04$ & & $1.972 \mathrm{E}+04$ & $1.972 \mathrm{E}+04$ & & \\
\hline Gasoline only (Btu/gal produced) & $1.589 \mathrm{E}+04^{\mathrm{c}}$ & $1.543 \mathrm{E}+04$ & & $1.972 \mathrm{E}+04$ & $1.986 \mathrm{E}+04$ & & \\
\hline Gasoline only (Btu/Btu HC produced) & 0.141 & 0.137 & & 0.175 & 0.176 & 0.001 & \\
\hline CG only (Btu/gal produced) & $1.689 \mathrm{E}+04^{\mathrm{c}}$ & $1.589 \mathrm{E}+04$ & & & & & \\
\hline CG only (Btu/Btu HC produced) & & 0.141 & & & & & \\
\hline RFG only (Btu/gal produced) & & $1.502 \mathrm{E}+04$ & & & & & \\
\hline RFG only (Btu/Btu HC produced) & & 0.133 & 0.133 & & & 0.001 & 0.134 \\
\hline
\end{tabular}

a CAAA $=$ Clean Air Act Amendments.

b Energy in plant fuel burned, natural gas, and electricity to produce diesel and jet fuel is held constant across runs.

c Energy in plant fuel burned, natural gas, and electricity to produce HCs in conventional gasoline is assumed to be the same for gasoline and diesel and jet fuel. 
to produce HCs for use in RFG is always lower than the amount required to produce them for $C G$. There is considerable variation among the RFGs.

\subsubsection{Other}

Some energy and crude oil is required to make the isobutylene for ether produced within the refinery. That energy requirement is implicitly included in this calculation of energy needed to produce HCs for RFG. To avoid doublecounting in the estimate of the energy required to produce ethers for RFG (which includes ether production, both internal and external to the refinery), an estimate of that internal energy use is subtracted in estimates of the energy required to produce ethers.

\subsubsection{Energy and Crude Oil Required to Produce MTBE}

Table 3.12 presents estimates of the amount of energy and crude oil required to produce MTBE. These estimates are based on a report by Chem Systems, Inc. (1992), which provides estimates of the amount of plant energy required for various MTBE production processes. This analysis assumes that the process that produces MTBE from field butanes is used (see Appendix H). Feedstock for the plant energy and feedstock for the butanes and methanol are estimated on the basis of Chem Systems, Inc. (1992); DeLuchi (1991, 1993); and Delucchi (1993).

This analysis assumes that the energy ratio of natural gas feedstock to methanol produced is 1.5 to 1 . The Chem Systems report suggests a lower ratio, but this higher ratio is consistent with sources cited by Delucchi. All the ether plant energy use is assigned to the production of the ether, but the fuel-gas by-products that are also produced are accounted for. Finally, the energy required to produce the field butanes and natural gas used in the system is assumed to be negligible.

As indicated above, some MTBE will be produced within the oil refinery. Table 3.13 presents the final energy requirements to produce MTBE, as a weighting of the energy required to produce MTBE within the refinery (and thus, without MTBE plant energy) and the energy required to produce MTBE in the MTBE plant.

\subsubsection{Energy and Crude Oil Required to Produce Ethanol}

The energy requirements for corn and ethanol production are derived from DeLuchi (1991, 1993) and Delucchi (1993). These reports contain an extensive analysis of various references that estimate the energy required to produce ethanol. On the basis of these references, Delucchi developed a base-case scenario and alternative scenarios of ethanol production and associated GHG emissions. The base case assumes that corn is used to produce ethanol. Delucchi considers this base case to be representative of current industry average practice. Table 3.14 presents the underlying energy use and crude oil use 
TABLE 3.12 MTBE Production from Field Butanes: Capacity of 500,000 Metric Tons per Year

\begin{tabular}{|c|c|c|c|c|c|c|c|c|c|c|c|}
\hline $\begin{array}{l}\text { Utility or Feedstock } \\
\text { Input }\end{array}$ & $\begin{array}{c}\text { Enthalpy } \\
\text { of Steam } \\
\text { (Btu/lb } \\
\text { steam) }\end{array}$ & $\begin{array}{l}\text { Units } \\
\text { per t } \\
\text { MTBE }\end{array}$ & $\begin{array}{c}\text { Energy } \\
\text { Content } \\
\left(10^{6} \mathrm{Btu} /\right. \\
\text { unit } \\
\text { input })\end{array}$ & $\begin{array}{c}\text { Energy to } \\
\text { Produce } \\
\text { Feedstock } \\
\left(10^{6} \mathrm{Btw} /\right. \\
\text { unit } \\
\text { input) }\end{array}$ & $\begin{array}{c}\text { Total } \\
\text { Energy } \\
\text { input } \\
\left(10^{6} \mathrm{Btu} / \mathrm{t}\right. \\
\text { MTBE) }\end{array}$ & $\begin{array}{l}\text { Total } \\
\text { Energy } \\
\text { Input } \\
\text { (Btu/gal } \\
\text { MTBE) }\end{array}$ & $\begin{array}{c}\text { Plant } \\
\text { Energy } \\
\text { Only } \\
\text { (Btu/gal } \\
\text { MTBE) }\end{array}$ & $\begin{array}{c}\text { Feedstock } \\
\text { for Plant } \\
\text { Energy } \\
\text { Only } \\
\text { (Btu/gal } \\
\text { MTBE) }\end{array}$ & $\begin{array}{c}\text { Process } \\
\text { Energy for } \\
\text { Butanes and } \\
\text { Feedstock for } \\
\text { MeOH } \\
\text { (Btu/gal } \\
\text { MTBE) }\end{array}$ & $\begin{array}{c}\text { Total } \\
\text { Energy to } \\
\text { Produce } \\
\text { Feedstock } \\
\text { Only } \\
\text { (Btu/gal } \\
\text { MTBE) }\end{array}$ & $\begin{array}{l}\text { Fuel Type for } \\
\text { Production } \\
\text { Energy }\end{array}$ \\
\hline 600-psi steam in tons & 1,380 & 0.67 & 2.760 & 0.585 & 2.24 & 6,314 & 5,209 & 1,105 & & 1,105 & Natural gas \\
\hline Electricity in $\mathbf{k W h}$ & $\mathrm{NA}^{\mathrm{b}}$ & 40.56 & 0.003 & 0.007 & 0.42 & 1,170 & 390 & 780 & & 780 & All fuel sources \\
\hline Natural gas in $10^{6} \mathrm{kcal}$ & NA & 0.07 & 3.968 & & 0.28 & 782 & 782 & 0 & & 0 & Natural gas \\
\hline Field butanes in $t$ & NA & 0.7655 & 42.957 & & 32.88 & 92,690 & & & 0 & 0 & Natural gas \\
\hline $\begin{array}{l}\text { Field butane by-product } \\
\text { credit in } 10^{6} \mathrm{kcal}\end{array}$ & & 0.72223 & 3.968 & & 2.87 & 8,073 & & & & & \\
\hline $\begin{array}{l}\text { Field butane process } \\
\text { losses }^{c}\end{array}$ & & & & & & 10,375 & & & 10,375 & & Natural gas \\
\hline Methanol in $t$ & NA & 0.3658 & 18.791 & 9.396 & 10.31 & 29,044 & & & 9,681 & 9,681 & Natural gas \\
\hline Total ${ }^{d}$ & & & & & & 121,868 & 6,381 & 1,885 & 20,056 & 11,666 & \\
\hline Total oil & & & & & & & 0 & 0 & 0 & 0 & \\
\hline
\end{tabular}

${ }^{\mathrm{a}} \mathrm{t}=$ metric ton $(2,200 \mathrm{lb}) ;$ ton $=$ short ton $(2,000 \mathrm{lb})$

b NA = not applicable.

c Process losses refer to the consumption of some of the butane feed as fuel rather than as feedstock.

d Totals are calculated by summing the first four inputs (ateam, electricity, natural gas, and butane) and the methanol input and subtracting by-product credits. Process loss is not added because it is already in the total through its inclusion as butane feed (fourth row). Including it in the total would result in double counting.

Sources: Chem Systems, Inc. (1992, Appendix IV, Table A4-40); DeLuchi (1993, Table J.1). 
TABLE 3.13 Weighted Btu Requirements for Ether Production

\begin{tabular}{|c|c|c|}
\hline \multirow[b]{2}{*}{ Fuels } & \multicolumn{2}{|c|}{$\begin{array}{l}\text { Energy Required } \\
\text { (Btu required/Btu } \\
\text { of ether produced) }\end{array}$} \\
\hline & Energy & Oil \\
\hline \multicolumn{3}{|l|}{ Summer } \\
\hline For MTBE only in RFG & 0.298 & 0.000 \\
\hline For ETBE only in RFG & 0.474 & 0.029 \\
\hline For MTBE in CG & 0.254 & 0.000 \\
\hline \multicolumn{3}{|l|}{ Winter } \\
\hline For MTBE only in RFG & 0.303 & 0.000 \\
\hline For MTBE in CG & 0.284 & 0.000 \\
\hline
\end{tabular}

TABLE 3.14 Delucchi's Base-Case

Estimate of Energy and Crude Oil

Required to Produce Ethanol

(Btu/Btu EtOH)

\begin{tabular}{ll} 
Energy & \\
Fertilizer & 0.194 \\
Feedstock recovery & 0.100 \\
Corn transportation & 0.025 \\
Fuel production & $\underline{0.680}$ \\
Total without by-product credit & 0.999 \\
Total with by-product credit & 0.880 \\
& \\
Crude oil & \\
Without by-product credit & 0.147 \\
With by-product credit & 0.083 \\
\hline
\end{tabular}

assumptions of Delucchi's base case for ethanol production. These assumptions are briefly discussed in Section 4 of this report when they are compared with alternative estimates of the energy and crude oil required to produce ethanol. Tables 3.3 and 3.6 use Delucchi's estimates of the energy and crude oil required to produce ethanol, giving credit for the production of by-products.

\subsubsection{Energy and Crude Oil Required to Produce ETBE}

The MTBE production process was adapted to develop estimates of the ETBE production process (Table 3.15). This process may slightly understate ETBE process energy, 
TABLE 3.15 ETBE Production Adapted from MTBE Production

\begin{tabular}{|c|c|c|c|c|c|c|c|c|c|c|c|}
\hline $\begin{array}{l}\text { Utility or Feedstock } \\
\text { Input }\end{array}$ & $\begin{array}{c}\text { Enthalpy } \\
\text { of Steam } \\
\text { (Btu/hb } \\
\text { steam) }\end{array}$ & $\begin{array}{l}\text { Units } \\
\text { per t } \\
\text { ETBE }\end{array}$ & $\begin{array}{c}\text { Energy } \\
\text { Content } \\
\left(10^{6} \mathrm{Btw} /\right. \\
\text { unit } \\
\text { input })\end{array}$ & $\begin{array}{c}\text { Energy to } \\
\text { Produce } \\
\text { Feedstock } \\
\left(10^{6} \mathrm{Btw}\right. \\
\text { unit } \\
\text { input) }\end{array}$ & $\begin{array}{c}\text { Total } \\
\text { Energy } \\
\text { Input } \\
\left(10^{6} \mathrm{Btu} / \mathrm{t}\right. \\
\text { ETBE })\end{array}$ & $\begin{array}{l}\text { Total } \\
\text { Energy } \\
\text { Input } \\
\text { (Btu/gal } \\
\text { ETBE) }\end{array}$ & $\begin{array}{l}\text { Plant } \\
\text { Energy } \\
\text { Only } \\
\text { (Btu/gal } \\
\text { ETBE) }\end{array}$ & $\begin{array}{c}\text { Feedstock } \\
\text { for Plant } \\
\text { Energy } \\
\text { Only } \\
\text { (Btu/gal } \\
\text { ETBE) }\end{array}$ & $\begin{array}{l}\text { Process } \\
\text { Energy for } \\
\text { Butanes and } \\
\text { Feedstock for } \\
\text { EtOH } \\
\text { (Btu/gal } \\
\text { ETBE) }\end{array}$ & $\begin{array}{l}\text { Total } \\
\text { Energy to } \\
\text { Produce } \\
\text { Feedstock } \\
\text { Only } \\
\text { (Btu/gal } \\
\text { ETBE) }\end{array}$ & $\begin{array}{l}\text { Fuel Type for } \\
\text { Production } \\
\text { Energy }\end{array}$ \\
\hline 600-psi steam in tons & 1,380 & 0.67 & 2,760 & 0.585 & 2.24 & 6,386 & 6,268 & 1,118 & & 1,118 & Natural gas \\
\hline Electricity in $\mathrm{kWh}$ & $N A^{c}$ & 40.56 & 0.003 & 0.007 & 0.42 & 1,189 & 394 & 789 & & 789 & All fuel sources \\
\hline Natural gas in $10^{6} \mathrm{kcal}$ & NA & 0.07 & 3.968 & & 0.28 & 791 & 791 & 0 & & $\mathbf{0}$ & Natural gas \\
\hline Field butanes in $t$ & NA & 0.650 & 42.036 & & 27.34 & 77,878 & & & & $\mathbf{0}$ & Natural gas \\
\hline $\begin{array}{l}\text { Field butane by-product } \\
\text { credit in } 10^{6} \mathrm{kcal}\end{array}$ & & 0.614 & 3.968 & & 2.43 & 6,996 & & & & & \\
\hline $\begin{array}{l}\text { Field butane process } \\
\text { losses }^{\mathbf{d}}\end{array}$ & & & & & & 8,722 & & & 8,722 & & Natural gas \\
\hline Ethanol in $t$ & NA & 0.4512 & 25.964 & 22.848 & 22.02 & 62,747 & & & 29,371 & 29,371 & Some oil \\
\hline Total $^{\theta}$ & & & & & & 142,050 & 6,454 & 1,906 & 38,093 & 31,277 & \\
\hline Total oil & & & & & & & 0 & 0 & 2,770 & 2,770 & \\
\hline
\end{tabular}

$\mathrm{t}=$ metric ton $(2,200 \mathrm{lb}) ;$ ton $=$ short ton $(2,000 \mathrm{lb})$.

b To estimate fossil energy input, the ethanol energy input should be subtracted from the total energy input.

c NA = not applicable.

d Process losses refer to the consumption of some butane feed as fuel rather than as feedstock.

- Totals calculated by summing the first four inputs (steam, electricity, natural gas, and butane) and the methanol input and subtracting by-product credits. Process loss is not added because it is already in the total through its inclusion as butane feed (fourth row). Including it in the total would result in double counting.

Sources: Adapted from Table 3.12; uses Delucchi's ethanol production estimates. 
because additional distillation steps are required in ETBE production to achieve the required water removal. The major adaptation was to substitute the energy required to produce ethanol for that required to produce methanol. As was the case for MTBE, this analysis assumes that some ETBE will be produced within the refinery and some outside. The weighted estimate of the energy required to produce the ETBE is also given in Table 3.13.

\subsubsection{Energy and Crude Oil Required to Produce Finished Fuels}

Columns 8 and 9 of Tables 3.3 and 3.6 provide the final estimates of the amount of energy and crude oil required to produce the various RFGs and CG. Less energy is required to produce RFG with MTBE than to produce RFG with ETBE or ethanol in each season only if the ethanol is new ethanol. If existing ethanol supplies are used, ethanol diverted for use in RFG is replaced by gasoline. Less crude oil is required to produce winter RFG with MTBE than to produce RFG with ethanol, but in the summer, all three RFGs require similar amounts of crude oil. Less energy is required to produce CG than to produce the base RFG in each season. More crude oil is required to produce CG than to produce all the RFGs.

\subsection{TOTAL ENERGY, FOSSIL ENERGY, AND CRUDE OIL REQUIRED}

Columns 10, 11, and 12 of Table 3.3 estimate the total energy, total fossil energy, and total crude oil requirements of year 2000 RFGs containing 2.1 wt\% oxygen, each of which is normalized to the base RFG in terms of delivered energy. Total energy as defined here is the sum of the energy content of the final fuel and energy consumed in production processes. It does not include the full energy cycle (e.g., some crude-oil field production energy and energy used in fuel transportation are not included). Table 3.16 converts these estimates into relative estimates, with the base being summer RFG with MTBE. The likely alternative to winter RFG with ethanol is winter RFG with MTBE, not the base RFG.

On a per-gallon and seasonal basis, the total energy requirement is between $0.6 \%$ and 1.3\% lower for RFG with ethanol (as ethanol or ETBE) than for RFG with MTBE, if the RFG with ethanol is made with existing ethanol (ethanol diverted from existing sources). The total energy requirement is between $1.3 \%$ and $1.8 \%$ higher if the RFG with ethanol is made with new ethanol. In all cases, $R F G$ requires more energy than $C G$.

The fossil energy requirement is lower for all the renewable-oxygenated RFGs than for MTBE-oxygenated RFGs - up to $2.2 \%$ lower on a per-gallon basis. In some cases, CG requires less fossil energy than $R F G$.

The amount of crude oil use associated with using RFGs with ETBE and ethanol is almost always higher than that estimated for using RFG with MTBE - up to $11 \%$ higher when winter RFGs are compared. Only RFG with ETBE made from new ethanol uses less crude oil than RFG with MTBE. In all cases, RFG requires less crude oil than CG, but the use of existing ethanol in winter RFG greatly reduces the crude oil saving relative to $C G$. 
TABLE 3.16 Energy Content and $\mathrm{CO}_{2}$-Equivalent Emissions of Summer and Winter RFGs Based on Delucchi's Estimate of Energy and Crude Oil Required to Produce Ethanol: Values Relative to Summer RFG with MTBE

\begin{tabular}{|c|c|c|c|c|}
\hline Fuel Type $^{\mathrm{a}}$ & $\begin{array}{l}\text { Total Energy } \\
\text { Required to } \\
\text { Deliver RFG }\end{array}$ & $\begin{array}{c}\text { Total } \\
\text { Fossil Energy } \\
\text { Required to } \\
\text { Deliver RFG }\end{array}$ & $\begin{array}{l}\text { Total Crude } \\
\text { Oil Required } \\
\text { to Deliver RFG }\end{array}$ & $\begin{array}{c}\mathrm{CO}_{2} \text {-Equivalent } \\
\text { Emissions }\end{array}$ \\
\hline \multicolumn{5}{|l|}{ Summer } \\
\hline RFG with MTBE at $2.1 \%$ & 1.000 & 1.000 & 1.000 & 1.000 \\
\hline $\begin{array}{l}\text { RFG with ETBE at } 2.1 \% \\
\text { (new EtOH) }\end{array}$ & 1.018 & 0.983 & 0.980 & 1.007 \\
\hline $\begin{array}{l}\text { RFG with ETBE at } 2.1 \% \\
\text { (existing EtOH) }\end{array}$ & 0.992 & 9.992 & 1.022 & 0.996 \\
\hline CG in PADD II & 0.987 & 0.987 & 1.119 & 0.998 \\
\hline \multicolumn{5}{|l|}{ Winter } \\
\hline RFG with MTBE at $2.1 \%$ & 0.981 & 0.981 & 0.983 & 0.962 \\
\hline $\begin{array}{l}\text { RFG with EtOH at } 2.1 \% \\
\text { (new EtOH) }\end{array}$ & 0.995 & 0.959 & 1.051 & 0.977 \\
\hline $\begin{array}{l}\text { RFG with EtOH at } 2.1 \% \\
\text { (existing EtOH) }\end{array}$ & 0.969 & 0.969 & 1.092 & 0.964 \\
\hline RFG with MTBE at $2.7 \%$ & 0.986 & 0.986 & 0.952 & 0.962 \\
\hline $\begin{array}{l}\text { RFG with EtOH at } 2.7 \% \\
\text { (new EtOH) }\end{array}$ & 1.003 & 0.956 & 1.039 & 0.980 \\
\hline $\begin{array}{l}\text { RFG with EtOH at } 2.7 \% \\
\text { (existing EtOH) }\end{array}$ & 0.969 & 0.969 & 1.092 & 0.965 \\
\hline CG in PADD II & 0.976 & 0.976 & 1.099 & 0.975 \\
\hline
\end{tabular}

a $2.1 \%$ and $2.7 \%$ refer to the oxygen content in weight percent. New EtOH $=$ incrementally produced ethanol as opposed to ethanol diverted from existing markets. Existing $\mathrm{EtOH}=$ ethanol diverted from existing markets.

Table 3.6 presents the total energy, fossil energy, and crude oil requirements of winter RFG containing $2.7 \mathrm{wt} \%$ oxygen. Table 3.16 converts the results of Table 3.6 into relative estimates. The relative results (versus the base-case $R F G$ ) are very similar to those for the RFGs containing $2.1 \mathrm{wt} \%$ oxygen.

An increase from 2.1 to $2.7 \mathrm{wt} \%$ in the oxygen content of RFG containing existing ethanol causes no significant change in its total energy, fossil energy, or crude oil requirements. Total energy requirements increase for the RFGs with MTBE and new ethanol over those of RFGs containing 2.1 w\% oxygen. Fossil energy requirements increase with greater use of MTBE and decline with greater use of new ethanol. Crude oil use decreases for both RFG with MTBE and RFG with new ethanol.

\subsection{GREENHOUSE GAS EMISSIONS OF REFORMULATED GASOLINE}

\subsubsection{Factors}

Table 3.17 presents estimates of the GHG, or $\mathrm{CO}_{2}$-equivalent, emissions of the various components of RFG. These estimates are derived from Delucchi's GHG model and 
TABLE 3.17 $\mathrm{CO}_{2}$-Equivalent Emissions of RFG
Components

\begin{tabular}{lc}
\hline \multicolumn{1}{c}{ Fuel } & $\begin{array}{c}\mathrm{CO}_{2} \text {-Equivalent } \\
\text { Emissions } \\
\text { (g/Btu of fuel) }\end{array}$ \\
\hline MTBE & 0.10133 \\
ETBE & 0.11152 \\
EtOH & 0.13390 \\
Summer HCs for CG & 0.10554 \\
Winter HCs for CG & 0.10304 \\
Summer HCs for RFG with MTBE & 0.10614 \\
Winter HCs for RFG with MTBE & 0.10165 \\
Summer HCs for RFG with ETBE & 0.10574 \\
Winter HCs for RFG with EtOH & 0.10186 \\
\hline
\end{tabular}

assume his base case for ethanol production. Alternative estimates of the GHG emissions associated with ethanol production are provided in Section 4.

Table 3.17 is based on Table G.1 in Appendix G, which is Delucchi's base case for alternative fuels as of August 1993. As stated previously, the GHG emissions associated with vehicle materials and assembly are not considered here. The estimates in grams per mile (g/mi) provided in Table G.1 can be converted into grams per Btu (g/Btu). With these two modifications, the GHG emissions of ethanol (and methanol) can be directly estimated from Table G.1. Delucchi's model was run several times to estimate the GHG emissions associated with MTBE only (i.e., the difference in emissions between CG with MTBE and CG without MTBE was used to derive the GHG emissions of MTBE). Once the GHG emissions associated with MTBE were estimated, the GHG emissions associated with ETBE were estimated by substituting data on GHG emissions from ethanol production for data on GHG emissions from methanol production. The fact that ethanol makes up a greater volume percent of ETBE than methanol does of MTBE was factored into the ETBE GHG emission calculation.

Delucchi provided estimates of the GHG emissions associated with the use of CG containing MTBE. This analysis assumes that this CG is a summer fuel. The GHG emissions associated with the HCs for this summer CG were disaggregated from those for MTBE. For HCs used in RFGs, the GHG emissions were based on the energy required to produce these $\mathrm{HCs}$ relative to the energy required to produce the HCs for CG. (The amount of energy required to produce the various HCs is presented in Table 3.10.)

\subsubsection{Results}

Tables 3.3 and 3.6 apply the factors presented in Table 3.17 to the energy content of the components of the various RFGs to derive total GHG emissions for the RFGs. Table 3.16 converts these estimates into relative estimates, with the base case being summer 
RFG with MTBE. Winter RFGs generate fewer $\mathrm{CO}_{2}$-equivalent emissions than summer $\mathrm{RFGs}$ when both are oxygenated with MTBE. Winter RFG with ethanol generates fewer emissions than summer RFG with ETBE as well. If new ethanol is used to supply ether feedstock (summer) or ethanol for oxygenate blending (winter), the resulting RFGs emit more GHGs (about $1 \%$ more in each case) than are produced if existing ethanol use is diverted to supply this ethanol. Similarly, use of new ethanol leads to more GHG emissions than use of MTBE. In some instances, the GHG emissions associated with CG are fewer than those associated with RFG.

\subsection{MOST LIKELY RESULTS}

The programwide impacts of using the RFGs analyzed in this section are reported in Section 5. The estimates presented in this section indicate that in general, a year-round program in which only RFG containing MTBE is used will use more total energy and fossil energy than would a program in which only CG is used. However, use of RFG with MTBE only will reduce crude oil requirements and perhaps reduce GHG emissions. All of these changes are likely to be on an order of a few percentage points or less. (This comparison assumes the use of summer fuels for 5.5 months of the year and winter fuels for 6.5 months.)

With respect to the ROS mandate, relatively little, if any, ETBE is likely to be used in the near term (subject to variations in the methanol/ethanol price relationship). RFG with ethanol will be used, and in the near term, much of the ethanol will be diverted from existing sources. Therefore, relative to the all-MTBE case, the ROS in the near term should reduce total energy and fossil energy use, increase crude oil use, and have virtually no effect on GHG emissions.

In the long term, both ETBE and ethanol will probably be used, and ethanol production capacity will increase so that more new ethanol will be used. The implications of these trends are explored more fully in Section 5. Use of RFG containing ETBE from new ethanol will likely increase total energy use, reduce fossil energy and crude oil use, and increase GHG emissions relative to use of RFG containing MTBE. These changes are all within a few percent or less. 


\section{ALTERNATIVE ESTIMATES OF THE IMPACTS OF USING REFORMULATED GASOLINE WITH ETHANOL ON ENERGY USE AND GREENHOUUSE GAS EMISSIONS}

\subsection{INTRODUCTION}

There is substantial uncertainty about the amount of energy that is required to produce ethanol from corn and the GHG emissions that are associated with the production and use of ethanol. The analysis of energy requirements and GHG emissions associated with using various oxygenates in RFG presented in Section 3 was based on Delucchi's base-case estimates of the energy and crude oil required to produce ethanol (DeLuchi 1991, 1993; Delucchi 1993b). This section analyzes the effects on the basis of alternative assumptions about ethanol's energy production requirements. Although Delucchi developed a number of alternative scenarios on the amount of energy and crude oil required to produce corn-based ethanol, this section uses two other references: estimates developed by the USDA (Conway et al. 1994) and estimates developed by Ho of Amoco Oil Company (Ho 1989). The USDA's estimates are approximately $25 \%$ lower than Delucchi's base-case estimates of the energy required to produce ethanol from corn, and Ho's are about $22 \%$ higher.

To analyze the effects of these different assumptions and estimates, the USDA and Ho estimates were input into Delucchi's model to generate alternative estimates of the GHG emissions associated with the use of ethanol. These alternative estimates of the energy and crude oil use and GHG emissions associated with the use of ethanol in RFG then served as input to the ANL model of energy requirements and GHG emissions associated with RFG. The effect of these alternative ethanol estimates on the energy and crude oil use and GHG emissions associated with the use of various oxygenates in RFG were then evaluated.

\subsection{DELUCCHI'S ESTIMATES OF ENERGY AND CRUDE OIL REQUIRED TO PRODUCE ETHANOL}

The RFG analysis presented in Section 3 is based on Delucchi's estimates of the amount of energy and crude oil required to produce ethanol and the GHG emissions associated with such production. (These estimates are thoroughly explained in DeLuchi 1991 and 1993 and Delucchi 1993). The derivation of these estimates is not repeated here except to highlight where they differ from the USDA and Ho estimates.

Table 4.1 presents Delucchi's base-case estimates of the amount of energy and crude oil required to produce ethanol, with and without credit given for by-products. These estimates are presented in Delucchi's reports and in the August 1993 version of his spreadsheet model. In his model, Delucchi characterizes the process energy consumed in several stages of fuel production: fertilizer manufacture, feedstock recovery, feedstock transportation, fuel production, fuel distribution, and liquid loss. The latter two stages are not included here in this analysis of the energy and crude oil required to produce ethanol. 
TABLE 4.1 Alternative Estimates of Energy and Crude Oil Required to Produce Ethanol

\begin{tabular}{|c|c|c|c|c|}
\hline $\begin{array}{l}\text { Reference and Fuel } \\
\text { Production Stage }\end{array}$ & $\begin{array}{c}\text { Energy Required } \\
\text { with No By-Product } \\
\text { Credits (Btu/Btu } \\
\text { EtOH) }\end{array}$ & $\begin{array}{c}\text { Energy Required } \\
\text { with By-Product } \\
\text { Credits (Btu/Btu } \\
\text { EtOH) }\end{array}$ & $\begin{array}{c}\text { Crude Oil } \\
\text { Share } \\
(\%)\end{array}$ & $\begin{array}{l}\text { Crude Oil } \\
\text { Required with By- } \\
\text { Product Credits } \\
\text { (Btu/Btu EtOH) }\end{array}$ \\
\hline \multicolumn{5}{|l|}{ Delucchi } \\
\hline $\begin{array}{l}\text { Fertilizer manu- } \\
\text { facture and } \\
\text { transport }\end{array}$ & 0.1936 & 0.1936 & 28 & \\
\hline Feedstock recovery & 0.1000 & 0.0050 & 67 & \\
\hline Corn transportation & 0.0255 & 0.0255 & 100 & \\
\hline Ethanol production & 0.6800 & 0.6560 & & \\
\hline Coal & 0.5300 & 0.5060 & 0 & \\
\hline Electricity & $0.05^{\mathrm{a}}$ & $0.05^{\mathrm{a}}$ & 0 & \\
\hline Total & 0.999 & 0.880 & & 0.083 \\
\hline \multicolumn{5}{|l|}{ USDA } \\
\hline $\begin{array}{l}\text { Fertilizer manu- } \\
\text { facture and } \\
\text { transport }\end{array}$ & 0.1749 & 0.1749 & 9.5 & \\
\hline Feedstock recovery & 0.0863 & 0.0233 & 63 & \\
\hline Corn transportation & 0.0098 & 0.0098 & 100 & \\
\hline Ethanol production & 0.4770 & 0.4613 & & \\
\hline Coal & 0.4770 & 0.4613 & 0 & \\
\hline Electricity & 0 & 0 & 0 & \\
\hline Total & 0.748 & 0.669 & & 0.041 \\
\hline \multicolumn{5}{|l|}{ Ho } \\
\hline $\begin{array}{l}\text { Fertilizer manu- } \\
\text { facture and } \\
\text { transport }\end{array}$ & 0.2105 & 0.2105 & 0 & \\
\hline Feedstock recovery & 0.2237 & 0.1317 & 100 & \\
\hline Corn transportation & 0.0255 & 0.0255 & 100 & \\
\hline Ethanol production & 0.7480 & 0.7090 & & \\
\hline Coal & 0.5920 & 0.5530 & 0 & \\
\hline Electricity & $0.052^{\mathrm{a}}$ & $0.052^{\mathrm{a}}$ & 0 & \\
\hline Total & 1.208 . & 1.077 & & 0.1572 \\
\hline
\end{tabular}

at 3,413 Btu/kWh. 
Although Delucchi's report provides a range of estimates for the coal required in the ethanol plant, this analysis uses the point estimate that he used for his base case. The crude oil share estimates include fuel crude oil, diesel fuel, and gasoline used in the various stages of ethanol production.

\subsection{USDA ESTIMATES OF ENERGY AND CRUDE OIL REQUIRED TO PRODUCE ETHANOL}

The USDA's estimates of the total energy requirements for ethanol production from corn were submitted as part of its comments on the EPA's ROS proposal. Delucchi compared the USDA estimates with his base-case estimates and provided the comparison to DOE in March 1994. The key differences are as follows:

1. The USDA's fertilizer requirement estimates are approximately $25 \%$ lower than Delucchi's: 29,000 versus 38,300 Btu/bushel. Delucchi believes the USDA estimate is probably a reasonable estimate of best practice, while his estimate is of average practice. His fertilizer estimate was lower than those in all but one of the reports he analyzed. (See Appendix G, Table G.2, for Delucchi's summary of various reports' estimates of the energy required to produce ethanol.)

2. The USDA estimates that farm energy requirements in the form of diesel fuel, gasoline, liquefied petroleum gas (LPG), and power are $19,000 \mathrm{Btu}$ per bushel; Delucchi's estimates are higher, at 22,000 Btu per bushel. Again, Delucchi believes that the USDA's estimates may be reasonable for best practice, while his are reasonable for average practice.

3. The USDA's estimate for seeds and chemicals required in farming is about 1,000 Btu per bushel below Delucchi's (5,900 versus 7,000 Btu per bushel). Still, both estimates represent $20 \%$ of their respective estimates of fertilizer requirements.

4. The USDA estimates approximately $800 \mathrm{Btu} / \mathrm{gal}$ of energy is used for corn transport; Delucchi estimates approximately 2,200 Btu/gal.

5. The USDA estimates that the energy required in ethanol plants is $47,400 \mathrm{Btu} / \mathrm{gal}$ for the dry milling process and 36,300 Btu/gal for the wet milling process. These estimates convert to $0.565 \mathrm{Btu}$ of coal per Btu of ethanol and $0.433 \mathrm{Btu}-c 0 a /$ Btu-ethanol, respectively. The USDA assumes that electricity can be cogenerated from the heat supplied by the coal. Delucchi's base case uses 0.53 Btu-coal/Btu-ethanol, with an additional 0.05 Btu-electricity/Btu-ethanol. Accounting for generation losses, Delucchi's' base case is approximately $0.68 \mathrm{Btu}$ total energy/Btu 
ethanol. Delucchi believes that the USDA's estimates are reasonable state-of-the-art estimates.

6. The USDA assumes that wet milling plants represent approximately two-thirds of all ethanol plants. Most of Delucchi's estimates were based on the assumption that ethanol plants are wet, not dry, milling plants.

7. The USDA does not give any by-product credits, although it does deduct the 7,000 Btu/gal that is used to dry by-products in the wet milling process. By-product credits in Delucchi's base case total approximately $12,000 \mathrm{Btu} / \mathrm{gal}$. These credits include credits for production of (1) ammonium sulfate from the flue gases of an ethanol facility (displaces fertilizer); (2) distillers dried grains and solubles (DDGS) produced by the ethanol-production process (displace soybean meal); and (3) fusel oil, a mixture of higher alcohols and higher esters, which is also produced by the ethanol production process (displaces the coal process fuel).

On the basis of this analysis of key differences, USDA estimates were put into Delucchi's model. Most of the inputs are straightforward. The USDA's estimates of the amount of crude oil used in all the stages of ethanol production were evaluated and found to be different from Delucchi's estimates; therefore, the USDA's were used. The USDA's crude oil share estimates are presented in Table 4.1.

This analysis also put by-product credits into the USDA estimates. Delucchi's estimates were used as a base, but credits for DDGS and fusel oil production were assumed to apply only to the wet milling plants. In addition, Delucchi indicated that the ammonium sulfate credit that he used should be reduced (by about $25 \%$ ) because best-practice plants, which the USDA has apparently assumed, will use low-sulfur coal and use it relatively efficiently. (This credit is actually subtracted directly from the fertilizer requirements before energy required to produce fertilizer is estimated in the Delucchi model.)

The results of all the above changes to Delucchi's model result in the USDA estimates presented in Table 4.1. The USDA's estimates of the energy required to produce ethanol are approximately $25 \%$ lower than Delucchi's, and its crude oil requirements are $50 \%$ lower.

\subsection{HO'S ESTIMATES OF ENERGY AND CRUDE OIL REQUIRED TO PRODUCE ETHANOL}

Ho's estimates were included in those surveyed by Delucchi, Ho's estimates are among those presented in Appendix G, Table G.2. This analysis used Delucchi's summary of Ho's estimates, supplementing it with additional detail from the original Ho paper to input its energy and crude oil use estimates into Delucchi's model. 
Specifically, estimates of the crude oil share of each stage of the ethanol production process and estimates of by-product credit by stage were drawn from Ho's paper. The estimates of crude oil share are presented in Table 4.1. Ho provides no credit for ammonium sulfate production, which may explain in part why his estimate of the energy required for fertilizer manufacture is higher than Delucchi's. Ho gives credit for DDGS and fusel crude oil production. Ho's credit for DDGS is virtually the same as Delucchi's, about 8,000 Btu/gal higher heating value (HHV). His credit for fusel oil production is higher (3,300 versus 2,000 Btu/gal HHV).

Other than the above information, Ho does not provide sufficient detail to allow a determination of the key differences between his assumptions and Delucchi's. They are simply input here as stated in his paper. Because Ho did not estimate the energy used to transport corn, Delucchi's estimate is used to complete Ho's estimates. The above changes to Delucchi's model result in the Ho estimates presented in Table 4.1. Ho's estimate of the energy required to produce ethanol is approximately $22 \%$ higher than DeLuchi's, and his estimate of crude oil requirements is $90 \%$ higher.

\subsection{GREENHOUSE GAS EMISSIONS ASSOCIATED WITH THE USE OF ETHANOL}

The USDA and Ho estimates of energy and crude oil use (with credit given for byproducts) were input to Delucchi's GHG emission model to estimate the implications of the two sets of estimates on GHG emissions. Results are presented in Table 4.2. They represent the full fuel cycle for these fuels. The USDA's estimates of GHG emissions from using ethanol are 20\% lower than Delucchi's; Ho's estimates are 10\% higher than Delucchi's.

\subsection{TOTAL ENERGY AND CRUDE OIL REQUIREMENTS AND GREENHOUSE GAS EMISSIONS OF REFORMULATED GASOLINE BASED ON ALTERNATIVE ESTIMATES OF ENERGY AND CRUDE OIL REQUIRED TO PRODUCE ETHANOL}

The USDA and Ho estimates of the energy required to produce ethanol (with credit given for by-products) and the GHG emission estimates derived from these energy production estimates were input to the ANL spreadsheet model. This model calculates the total energy, fossil energy, and crude oil requirements and GHG emissions of various RFGs. The resulting tables are presented in Appendix H; they are comparable to Tables 3.3 and 3.6, which use Delucchi's ethanol estimates. A summary of the estimates is presented in Table 4.3. Table 4.4 converts the estimates into relative per-gallon estimates, with the base case being summer RFG containing MTBE.

TABLE 4.2 Various Estimates of $\mathrm{CO}_{2}$-Equivalent Emissions of

Ethanol and ETBE

\begin{tabular}{lccc}
\hline & \multicolumn{3}{c}{$\begin{array}{c}\text { Emissions per Study } \\
\text { (g/Btu of fuel) }\end{array}$} \\
\cline { 2 - 4 } Fuel & Delucchi & USDA & Ho \\
\hline ETBE & 0.11152 & 0.10093 & 0.11695 \\
Ethanol & 0.13390 & 0.10899 & 0.14667 \\
\hline
\end{tabular}


TABLE 4.3 Energy Content and $\mathrm{CO}_{2}$-Equivalent Emissions of Summer and Winter RFGs Based on Alternative Estimates of Energy and Crude Oil Required to Produce Ethanol: Absolute Values

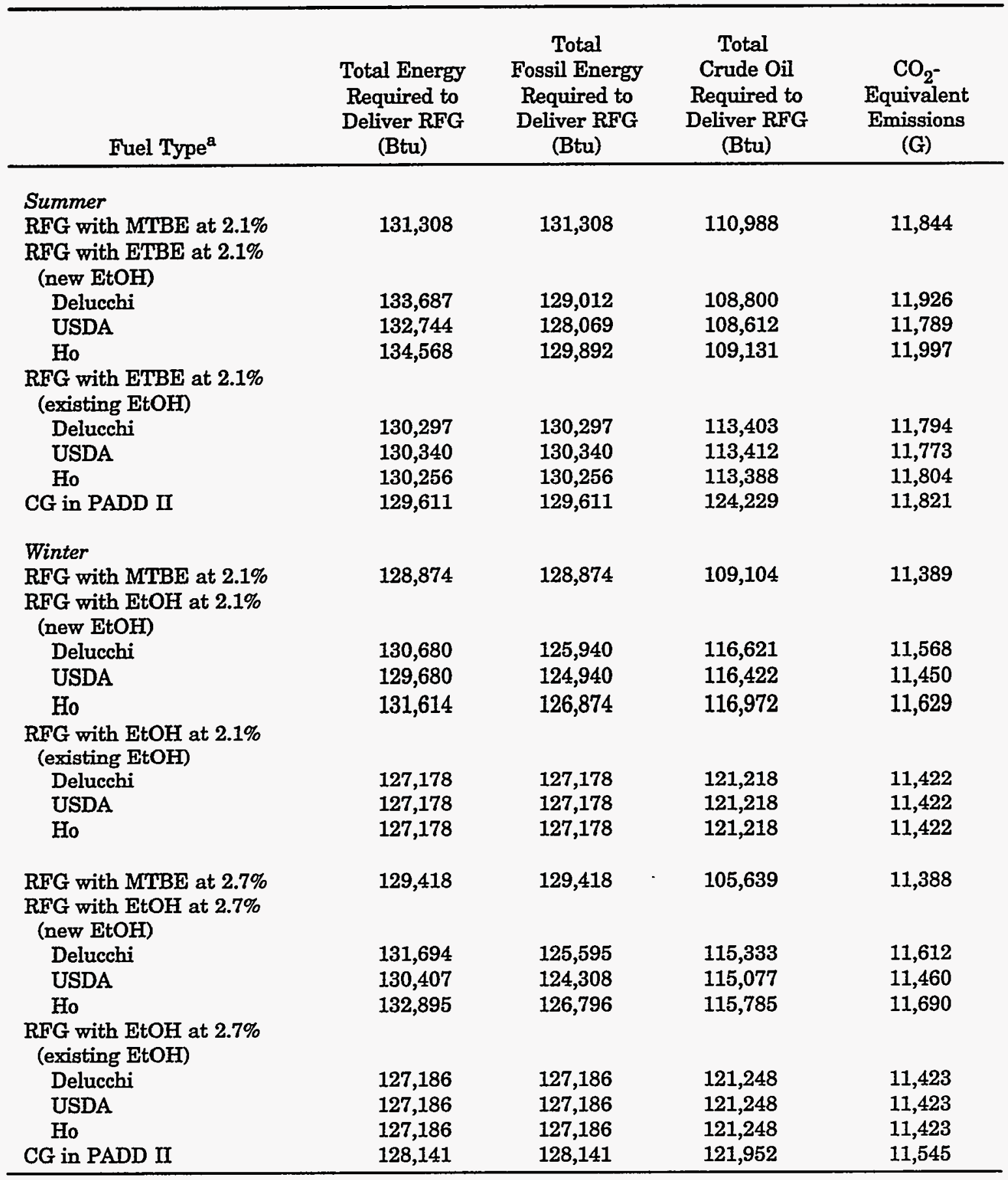

${ }^{a} 2.1 \%$ and $2.7 \%$ refer to oxygen content in weight percent. New EtOH $=$ incrementally produced ethanol as opposed to ethanol diverted from existing markets. Existing EtOH = ethanol derived from existing markets. 
TABLE 4.4 Energy Content and $\mathrm{CO}_{2}$-Equivalent Emissions of Summer and Winter RFGs Based on Alternative Estimates of Energy and Crude Oil Required to Produce Ethanol: Values Relative to Summer RFG with MTBE

\begin{tabular}{|c|c|c|c|c|}
\hline Fuel Type ${ }^{a}$ & $\begin{array}{l}\text { Total Energy } \\
\text { Required to } \\
\text { Deliver RFG }\end{array}$ & $\begin{array}{l}\text { Total } \\
\text { Fossil Energy } \\
\text { Required to } \\
\text { Deliver RFG }\end{array}$ & $\begin{array}{c}\text { Total } \\
\text { Crude Oil } \\
\text { Required to } \\
\text { Deliver RFG }\end{array}$ & $\begin{array}{l}\mathrm{CO}_{2-}^{-} \\
\text {Equivalent } \\
\text { Emissions }\end{array}$ \\
\hline \multicolumn{5}{|l|}{ Summer } \\
\hline $\begin{array}{l}\text { RFG with MTBE at } 2.1 \% \\
\text { RFG with ETBE at } 2.1 \% \\
\text { (new EtOH) }\end{array}$ & 1.000 & 1.000 & 1.000 & 1.000 \\
\hline Delucchi & 1.018 & 0.983 & 0.980 & 1.007 \\
\hline USDA & 1.011 & 0.975 & 0.979 & 0.995 \\
\hline Ho & 1.025 & 0.989 & 0.983 & 1.013 \\
\hline \multicolumn{5}{|l|}{$\begin{array}{l}\text { RFG with ETBE at } 2.1 \% \\
\text { (existing EtOH) }\end{array}$} \\
\hline Delucchi & 0.992 & 0.992 & 1.022 & 0.996 \\
\hline USDA & 0.993 & 0.993 & 1.022 & 0.994 \\
\hline Ho & 0.992 & 0.992 & 1.022 & 0.997 \\
\hline CG in PADD II & 0.987 & 0.987 & 1.119 & 0.998 \\
\hline \multicolumn{5}{|l|}{ Winter } \\
\hline $\begin{array}{l}\text { RFG with MTBE at } 2.1 \% \\
\text { RFG with EtOH at } 2.1 \% \\
\text { (new EtOH) }\end{array}$ & 0.981 & 0.981 & 0.983 & 0.962 \\
\hline Delucchi & 0.995 & 0.959 & 1.051 & 0.977 \\
\hline USDA & 0.988 & 0.952 & 1.049 & 0.967 \\
\hline Ho & 1.002 & 0.966 & 1.054 & 0.982 \\
\hline \multicolumn{5}{|l|}{$\begin{array}{l}\text { RFG with EtOH at } 2.1 \% \\
\text { (existing EtOH) }\end{array}$} \\
\hline Delucchi & 0.969 & 0.969 & 1.092 & 0.964 \\
\hline USDA & 0.969 & 0.969 & 1.092 & 0.964 \\
\hline Ho & 0.969 & 0.969 & 1.092 & 0.964 \\
\hline $\begin{array}{l}\text { RFG with MTBE at } 2.7 \% \\
\text { RFG with EtOH at } 2.7 \% \\
\text { (new EtOH) }\end{array}$ & 0.986 & 0.986 & 0.952 & 0.961 \\
\hline Delucchi & 1.003 & 0.956 & 1.039 & 0.980 \\
\hline USDA & 0.993 & 0.947 & 1.037 & 0.968 \\
\hline Ho & 1.012 & 0.966 & 1.043 & 0.987 \\
\hline \multicolumn{5}{|l|}{$\begin{array}{l}\text { RFG with EtOH at } 2.7 \% \\
\text { (existing EtOH) }\end{array}$} \\
\hline Delucchi & 0.969 & 0.969 & 1.092 & 0.964 \\
\hline USDA & 0.969 & 0.969 & 1.092 & 0.964 \\
\hline Ho & 0.969 & 0.969 & 1.092 & 0.964 \\
\hline CG in PADD II & 0.976 & 0.976 & 1.099 & 0.975 \\
\hline
\end{tabular}

a $2.1 \%$ and $2.7 \%$ refer to oxygen content in weight percent. New EtOH = incrementally produced ethanol as opposed to ethanol diverted from existing markets. Existing $\mathrm{EtOH}=$ ethanol derived from existing markets. 
Table 4.3 indicates that using the alternative estimates of energy and crude oil to produce ethanol results in very small changes (relative to Delucchi's estimates) in total RFG energy and crude oil use and GHG emissions. For example (on the basis of only the new ethanol estimates), the USDA estimate of the amount of energy required to produce ethanol, which is $25 \%$ lower than Delucchi's, translates into a reduction of $0.7 \%$ to $1 \%$ in the total energy or fossil energy requirements of a gallon of RFG containing ethanol or ETBE. The 50\% reduction from Delucchi's estimate of the amount of crude oil used in ethanol production translates into a $0.2 \%$ reduction in the total crude oil requirements of a gallon of RFG containing ethanol or ETBE. The biggest change is in the $\mathrm{CO}_{2}$ estimates; the USDA's estimates lead to a $1 \%$ to $1.3 \%$ reduction, relative to Delucchi's estimates, in the $\mathrm{CO}_{2}$ emissions associated with RFG containing ethanol or ETBE.

Table 4.4 indicates that use of the USDA and Ho estimates results in only one change in the direction of relative $R F G$ effects. In that one case, the USDA estimates indicate a $0.5 \%$ decrease in $\mathrm{CO}_{2}$ emissions as a result of using summer RFG with ETBE (new ethanol) relative to summer RFG with MTBE, while Delucchi estimates indicate a $0.7 \%$ increase. 


\section{PROGRAMWIDE ENERGY USE AND GREENHOUSE GAS EMISSION EFFECTS OF THE RENEWABLE OXYGENATE STANDARD}

In Section 5, the results of Sections 2,3, and 4 of this report are used to determine the national energy and GHG consequences of the ROS. The programwide impacts of fuel mixes that comply with the ROS are compared with impacts of RFG oxygenated only with MTBE. CG is also compared with RFG. Likely near-term and long-term operation of the program is evaluated on the basis of the assumption that $30 \%$ of the RFG will be oxygenated (i.e., the phase-in period is not evaluated).

Required volumes of each type of RFG were derived from the demand estimates in Section 2. Table 5.1 presents these volumes in base RFG-equivalent units. ${ }^{30}$ In the nearterm analysis, ethanol is assumed to be the only renewable oxygenate available and its use is assumed to be restricted to the winter. ${ }^{31}$ In the long-term analysis, it is assumed that ETBE will also be available and that oxygenation with renewables will occur year-round, with ethanol being used in the winter and ETBE being used in the summer. For comparative purposes, total RFG demand is held constant for the near-term and long-term cases.

The program-level impacts are estimated by multiplying the volume of each type of fuel (taken from Table 5.1) by the corresponding per-gallon energy consumption or GHG emission factors (taken from Table 3.3 [non-OG RFG] or Table 3.6 [OPRG] for the Delucchi base case or taken from the analogous tables in Appendix $\mathrm{H}$ for USDA or Ho alternative estimates of energy required to produce ethanol). The result of this calculation is total energy use in Btu/year (or $\mathrm{CO}_{2}$-equivalent/year) for the program weighted by fuel type. These obsolete results and relative results are reported in Tables 5.2 and 5.3 for the near-term and Tables 5.4 and 5.5 for the long-term.

For example, the following equation calculates the total crude oil requirement of base $\mathrm{RFG},{ }^{32}$ weighted by fuel type, on the basis of Tables 5.1, 3.3, and 3.6: [(16.1e9 gal summer $\mathrm{RFG} / \mathrm{yr})(110,988 \mathrm{Btu} / \mathrm{gal})]+[(10.6 \mathrm{e} 9 \mathrm{gal}$ winter RFG/yr) $(109,104 \mathrm{Btu} / \mathrm{gal})]+[(8.5 \mathrm{e} 9 \mathrm{gal}$ winter RFG-OG/year) $(105,639 \mathrm{Btu} / \mathrm{gal})]=3.84 \mathrm{e} 15 \mathrm{Btu} / \mathrm{year}$ of crude oil consumed.

Differences between results calculated with the values in the tables and those reported in Tables 5.2 and 5.4 are due to rounding in the tables.

Table 5.2 summarizes the near-term, programwide impacts (on annual total energy, fossil energy, and crude oil requirements and on GHG emission) from using (1) RFG with

30 Base RFG is summer, MTBE-oxygenated RFG containing 2.1 wt\% oxygen.

31 Recall that ethanol may be used during the summer under the ROS, but it does not qualify for renewable credit.

32 This amount will be the same for Delucchi, USDA, and Ho, since no ethanol is involved. 
TABLE 5.1 Volumes of Fuels Used for Programwide Impact Analysis ${ }^{a}$

\begin{tabular}{lc}
\hline \multicolumn{1}{c}{ Item } & $\begin{array}{c}\text { Base-RFG- } \\
\text { Equivalent } \\
\left(10^{9} \text { gal }\right)^{b}\end{array}$ \\
\hline Base RFG used & \\
Summer RFG with MTBE & 16.1 \\
Winter Non-OG RFG with MTBE & 10.6 \\
Winter OPRG with MTBE & 8.5 \\
& \\
Renewables used in winter only & \\
Summer RFG with MTBE & 16.1 \\
Winter Non-OG RFG with MTBE & 4.7 \\
Winter Non-OG RFG with EtOH & 5.9 \\
Winter OPRG with MTBE & 3.8 \\
Winter OPRG with EtOH & 4.7 \\
& \\
Renewables used year-round & 11.3 \\
Summer RFG with MTBE & 4.8 \\
Summer RFG with ETBE & 7.4 \\
Winter Non-OG RFG with MTBE & 3.2 \\
Winter Non-OG RFG with EtOH & 5.9 \\
Winter OPRG with MTBE & 2.5 \\
Winter OPRG with EtOH & \\
CG used in RFG areas & 16.1 \\
Summer & 19.1 \\
Winter & \\
\hline
\end{tabular}

a Volumes are consistent with Section 2 demand calculations. Volumes of RFG presented in this table have been rounded, resulting in an apparent difference in volumes for various scenarios presented. Unrounded volumes have been used to calculate the results presented in Tables 5.2 through 5.5.

b Base RFG is summer RFG with MTBE containing $2.1 \mathrm{wt} \%$ oxygen. 
TABLE 5.2 Programwide Impacts of the ROS in the Near Term: Absolute Values

\begin{tabular}{lcccc}
\hline \multicolumn{1}{c}{ Item } & $\begin{array}{c}\text { Total } \\
\text { Energy } \\
\text { Requirement } \\
\text { (Btu/yr) }\end{array}$ & $\begin{array}{c}\text { Total Fossil } \\
\text { Energy } \\
\text { Requirement } \\
\text { (Btu/yr) }\end{array}$ & $\begin{array}{c}\text { Total } \\
\text { Crude Oil } \\
\text { Requirement } \\
\text { (Btu/yr) }\end{array}$ & $\begin{array}{c}\mathrm{CO}_{2-} \\
\text { Equivalent } \\
\text { Emissions } \\
\text { (g/yr) }\end{array}$ \\
\hline $\begin{array}{l}\text { Base RFG used } \\
\text { Renewables used in winter only }\end{array}$ & $4.58 \mathrm{E}+15$ & $4.58 \mathrm{E}+15$ & $3.84 \mathrm{E}+15$ & $4.08 \mathrm{E}+14$ \\
$\quad$ Delucchi & $4.58 \mathrm{E}+15$ & $4.55 \mathrm{E}+15$ & $3.96 \mathrm{E}+15$ & $4.09 \mathrm{E}+14$ \\
USDA & $4.57 \mathrm{E}+15$ & $4.55 \mathrm{E}+15$ & $3.96 \mathrm{E}+15$ & $4.09 \mathrm{E}+14$ \\
$\quad$ Ho & $4.58 \mathrm{E}+15$ & $4.56 \mathrm{E}+15$ & $3.96 \mathrm{E}+15$ & $4.09 \mathrm{E}+14$ \\
CG used in RFG areas & $4.54 \mathrm{E}+15$ & $4.54 \mathrm{E}+15$ & $4.33 \mathrm{E}+15$ & $4.11 \mathrm{E}+14$ \\
\hline
\end{tabular}

TABLE 5.3 Programwide Impacts of the ROS in the Near Term: Values Relative to Base RFG

\begin{tabular}{lcccc}
\hline \multicolumn{1}{c}{ Item } & $\begin{array}{c}\text { Total } \\
\text { Energy } \\
\text { Requirement }\end{array}$ & $\begin{array}{c}\text { Total Fossil } \\
\text { Energy } \\
\text { Requirement }\end{array}$ & $\begin{array}{c}\text { Total } \\
\text { Crude Oil } \\
\text { Requirement }\end{array}$ & $\begin{array}{c}\mathrm{CO}_{2-} \\
\text { Equivalent } \\
\text { Emissions }\end{array}$ \\
\hline $\begin{array}{l}\text { Base RFG used } \\
\text { Renewables used in winter only }\end{array}$ & 1 & 1 & 1 & 1 \\
$\quad$ Delucchi & 0.999 & 0.994 & 1.031 & 1.002 \\
USDA & 0.997 & 0.992 & 1.031 & 1.000 \\
Ho & 0.999 & 0.994 & 1.031 & 1.003 \\
CG used in RFG areas & 0.990 & 0.990 & 1.127 & 1.007 \\
\hline
\end{tabular}

TABLE 5.4 Programwide Impacts of the ROS in the Long Term: Absolute Values

\begin{tabular}{lcccc}
\hline Item & $\begin{array}{c}\text { Total } \\
\text { Energy } \\
\text { Requirement } \\
\text { (Btu/yr) }\end{array}$ & $\begin{array}{c}\text { Total Fossil } \\
\text { Energy } \\
\text { Requirement } \\
\text { (Btu/yr) }\end{array}$ & $\begin{array}{c}\text { Total } \\
\text { Crude Oil } \\
\text { Requirement } \\
\text { (Btu/yr) }\end{array}$ & $\begin{array}{c}\mathrm{CO}_{2^{-}} \\
\text {Equivalent } \\
\text { Emissions } \\
\text { (g/yr) }\end{array}$ \\
\hline $\begin{array}{l}\text { Base RFG used } \\
\text { Renewables used in winter only }\end{array}$ & $4.58 \mathrm{E}+15$ & $4.58 \mathrm{E}+15$ & $3.84 \mathrm{E}+15$ & $4.08 \mathrm{E}+14$ \\
$\begin{array}{l}\text { Weighted } \\
\text { Delucchi }\end{array}$ & & & & \\
$\quad$ USDA & $4.58 \mathrm{E}+15$ & $4.56 \mathrm{E}+15$ & $3.91 \mathrm{E}+15$ & $4.09 \mathrm{E}+14$ \\
Ho & $4.57 \mathrm{E}+15$ & $4.55 \mathrm{E}+15$ & $3.91 \mathrm{E}+15$ & $4.08 \mathrm{E}+14$ \\
100\% new & $4.58 \mathrm{E}+15$ & $4.56 \mathrm{E}+15$ & $3.91 \mathrm{E}+15$ & $4.09 \mathrm{E}+14$ \\
Delucchi & & & & \\
USDA & $4.60 \mathrm{E}+15$ & $4.55 \mathrm{E}+15$ & $3.88 \mathrm{E}+15$ & $4.10 \mathrm{E}+14$ \\
$\quad$ Ho & $4.59 \mathrm{E}+15$ & $4.54 \mathrm{E}+15$ & $3.87 \mathrm{E}+15$ & $4.08 \mathrm{E}+14$ \\
CG used in RFG areas & $4.61 \mathrm{E}+15$ & $4.56 \mathrm{E}+15$ & $3.88 \mathrm{E}+15$ & $4.10 \mathrm{E}+14$ \\
& $4.54 \mathrm{E}+15$ & $4.54 \mathrm{E}+15$ & $4.33 \mathrm{E}+15$ & $4.115 \mathrm{E}+14$ \\
\hline
\end{tabular}


TABLE 5.5 Programwide Impacts of the ROS in the Long Term: Values Relative to Base RFG

\begin{tabular}{lcccc}
\hline \multicolumn{1}{c}{ Item } & $\begin{array}{c}\text { Total } \\
\text { Energy } \\
\text { Requirement }\end{array}$ & $\begin{array}{c}\text { Total Fossil } \\
\text { Energy } \\
\text { Requirement }\end{array}$ & $\begin{array}{c}\text { Total } \\
\text { Crude Oil } \\
\text { Requirement }\end{array}$ & $\begin{array}{c}\text { CO }_{2^{-}} \\
\text {Equivalent } \\
\text { Emissions }\end{array}$ \\
\hline $\begin{array}{l}\text { Base RFG used } \\
\text { Renewables used in winter only }\end{array}$ & 1 & & 1 & 1 \\
$\quad$ Weighted & & 1 & & \\
Delucchi & 0.999 & 0.995 & 1.017 & 1.001 \\
USDA & 0.998 & 0.993 & 1.017 & 0.999 \\
Ho & 1.000 & 0.995 & 1.017 & 1.001 \\
100\% new & & & & \\
Delucchi & 1.004 & 0.993 & 1.009 & 1.003 \\
USDA & 1.002 & 0.990 & 1.008 & 0.999 \\
Ho & 1.006 & 0.995 & 1.010 & 1.005 \\
CG used in RFG areas & 0.990 & 0.990 & 1.127 & 1.007 \\
\hline
\end{tabular}

MTBE only (base RFG), (2) RFG that satisfies the ROS requirement (containing $30 \%$ renewable oxygenates), and (3) CG. Table 5.3 presents data on the effects of the ROS requirement on using RFG containing MTBE only. Meeting the ROS is estimated to lower fossil energy use by $0.6-0.8 \%$ from that of the base case, but crude oil use is $3.1 \%$ higher and GHG emissions are either equal or up to $0.3 \%$ higher.

The near-term results presented for the fuel mix have been calculated by weighting new and existing ethanol. As defined in Sections 3 and 4, "existing ethanol" is ethanol diverted from existing markets. "New ethanol" is produced incrementally (i.e., additional) to that produced for existing markets. The analysis estimates that about $60 \%$ of the ethanol used to satisfy the ROS in the near term will be new. The source of the new ethanol will be current excess capacity plus additional winter capacity projected by EPA for 1996.

Tables 5.4 and 5.5 present the same information as Tables 5.2 and 5.3, but for the long-term analysis. Because the use of existing and new ethanol to satisfy ROS requirements is likely to be different in the long term, two alternatives are presented. Weighted results are based on the same weighting of new and existing ethanol that is used for the near-term analysis. Ethanol defined as "100\% new" is based on the assumption that all ethanol used in RFG is new. These examples are designed to show what the weighting might be; that they are not projections. The weighting assumptions are applied to ethanol blended directly during the winter and ethanol used to make ETBE for summer use.

In the long-term, on the basis of using "weighted" sources of ethanol, implementation of the ROS should reduce fossil energy use by $0.5 \%$ to $0.7 \%$, increase crude oil use by $1.6 \%$, and either reduce GHG emissions by $0.1 \%$ or raise them $0.2 \%$ at most. Use of $100 \%$-new ethanol should decrease fossil energy use by about $0.5 \%$ to $1.0 \%$, increase crude oil use by $0.8 \%$ to $1.0 \%$, and either reduce GHG emissions by $0.1 \%$ or raise them $0.5 \%$ at most. 
Tables 5.3 and 5.5 suggest that meeting the ROS will have the following outcomes relative to using RFG with MTBE only, both for the near and long term:

1. The ROS will result in a small decrease in fossil energy use that is no greater than $1 \%$.

2. The ROS will result in an increase in crude oil use of about 1-3\%.

3. The ROS will have essentially no effect on GHG emissions as long as corn-based ethanol is used. Large uncertainties are associated with estimating the GHG emissions of various fuels. This analysis generates differences among estimates on the order of about $0.5 \%$ or less. Given the uncertainties associated with GHG estimates, the conclusion is that the RFGs containing various oxygenates are essentially no different in terms of their GHG emissions.

4. Using alternative estimates (e.g., USDA and Ho) of the amount of energy and crude oil required to produce ethanol results in only very small (at most $0.4 \%$ ) programwide impacts.

The tables also indicate that using RFG rather than CG will (1) slightly increase fossil energy use, (2) substantially reduce crude oil use, and (3) probably slightly reduce GHG emissions. Because only a small fraction of RFG is oxygenate, differences between fuels that hinge on differences between oxygenates (e.g., the crude oil content of ethanol versus that of MTBE) are much smaller than the differences between oxygenates. 


\section{CONCLUSIONS}

\subsection{ETHANOL DEMAND}

The ROS is likely to lead to some displacement of ethanol from existing markets, particularly in the near term. The fact that some areas that had opted into the RFG program have recently opted out may have decreased this potential somewhat, but not completely.

- During the first year, under the $15 \%$ renewable requirement and at current ethanol production capacity, about $15 \%$ of the ethanol would have to be diverted to satisfy the ROS over a full winter season. For the front-loaded case, $83 \%$ of the ethanol would have to be diverted.

- In the near term, under the $30 \%$ renewable requirement and at higher ethanol production capacity, $25 \%$ of the ethanol would have to be diverted to satisfy the ROS over a full winter season. For the frontloaded case, $100 \%$ of the ethanol would have to be diverted for use in RFG.

- In the long term, if ethanol production is at 1996 levels, $34 \%$ of the ethanol would have to be diverted to meet winter-only renewable use. This result suggests that ethanol capacity (or inventory) is likely to expand beyond near-term levels.

- In all cases, at current stock levels of ethanol, maximum inventory drawdown would reduce but not eliminate the diversion of ethanol during the winter.

- Year-round oxygenation of renewables would eliminate the need for diverting ethanol.

- In all cases, more ethanol would need to be transported to RFG areas, even with maximum use of credit trading. Further study of the ethanol logistics system is warranted to determine the importance of such increases.

\subsection{ENERGY USE AND GREENHOUSE GAS EMISSIONS OF REFORMULATED GASOLINE}

If corn-based ethanol is used, the ROS will have a small impact on energy use and GHG emissions associated with RFG production and use.

- Relative to RFG oxygenated with MTBE only, RFG oxygenated with ethanol (both directly and with ethanol in ETBE) can be expected to 
slightly reduce fossil energy use, increase crude oil use, and have essentially no effect on GHG emissions.

- If the ROS is implemented, the increase in crude oil requirements would be greatest if ethanol were the only renewable oxygenate. The programwide impact would be approximately $3 \%$.

- The effects of the ROS at the programwide level on fossil energy requirements and GHG emissions would all be very small: $1 \%$ or less. Given the uncertainty associated with estimating GHG emissions, the conclusion is that the ROS would have essentially no effect on GHG emissions.

In this analysis, using alternative estimates of the amount of energy required to produce ethanol from corn made little difference on the effects of the ROS. First of all, ethanol represents a small portion of a gallon of renewable RFG. Moreover, any differences between estimates of the energy required to produce ethanol are further diminished over a programwide level, since only $30 \%$ of the RFG must be oxygenated with renewables under the ROS.

- When the two most divergent estimates of the energy required to produce ethanol were used, resultant estimates of fossil energy and crude oil requirements and GHG emissions were found to differ by only $1-2 \%$ on a per-gallon basis.

- On a programwide level, the differences in results for the alternative ethanol estimates are $0.5 \%$ or less for all categories for use of both weighted and 100\%-new ethanol. Differences of this magnitude should be considered insignificant. 


\section{REFERENCES}

Chem Systems, Inc., 1992, The Global MTBE Business, Appendixes, July.

Conway, R., et al., 1994, An Analysis of the Total Energy Requirements for Ethanol Manufacture from Corn, U.S. Department of Agriculture, Jan. 31.

Delucchi, M.A., 1993, Revisions to the Greenhouse Gas Emissions Model Used in "Emissions of Greenhouse Gases from the Use of Transportation Fuels and Electricity," draft, prepared by University of California, Davis, Calif., Aug.

DeLuchi, M.A., 1991, Emissions of Greenhouse Gases from the Use of Transportation Fuels and Electricity, ANL/ESD/TM-22, Vol. 1, Argonne National Laboratory, Argonne, Ill., Nov.

DeLuchi, M.A., 1993, Emissions of Greenhouse Gases from the Use of Transportation Fuels and Electricity, ANL/ESD/TM-22, Vol. 2, Argonne National Laboratory, Argonne, Ill., Nov.

DOE, 1994, Estimating the Cost and Effects of Reformulated Gasolines, DOE/PO-0030, U.S. Department of Energy, Office of Policy, Washington, D.C., Dec.

EIA, 1990, The U.S. Petroleum Refining Industry in the 1980s, DOE/EIA-0536, U.S. Department of Energy, Energy Information Administration, Washington, D.C.

EIA, 1994, Petroleum Supply Monthly, U.S. Department of Energy, Energy Information Administration, Washington, D.C., Jan.

EPA, 1994a, Final Regulatory Impact Analysis for the Renewable Oxygenate Standard, U.S. Environmental Protection Agency, June 30.

EPA, 1994b, questions and answers published electronically via the public information computer maintained by the U.S. Environmental Protection Agency.

Hadder, J., 1994, letter from Hadder, Oak Ridge National Laboratory, Oak Ridge, Tenn., to B. McNutt, U.S. Department of Energy, Jan. 10.

Ho, S.P., 1989, “Global Warming Impact of Ethanol Versus Gasoline," presented at 1989 National Conference on Clean Air Issues and America's Motor Fuel Business, Washington, D.C., Oct.

Lax, D., 1994, letter from Lax, American Petroleum Institute, to B. McNutt, U.S. Department of Energy, Jan. 3.

Marland, G., and A.F. Turhollow, 1991, $\mathrm{CO}_{2}$ Emission from the Production and Combustion of Fuel Ethanol from Corn, Oak Ridge National Laboratory, Oak Ridge, Tenn., Feb.

New Fuels Report, 1993-1994, various issues, Inside Washington Publishers, Washington, D.C. 
NPC, 1993, U.S. Petroleum Refining: Meeting Requirements for Cleaner Fuels and Refineries, National Petroleum Council, Washington, D.C., Aug.

ORNL, 1994, Energy Data for Winter RFG Production: Ethers versus Ethanol, Oak Ridge National Laboratory, Oak Ridge, Tenn., Jan. 10

Singh, M., 1994a, Energy Requirements and $\mathrm{CO}_{2}$-Equivalent Emissions of $\mathrm{RFG}$, sponsor report, Argonne National Laboratory, Argonne, Ill., Mar. 24.

Singh, M. 1994b, Analysis Memorandum: Energy Requirements and $\mathrm{CO}_{2}$-Equivalent Emissions of RFG, sponsor report, Argonne National Laboratory, Argonne, Ill., June 6.

Singh, M., and B.D. McNutt, 1993, Energy and Crude Oil Input Requirements for the Production of Reformulated Gasolines, ANL/ESD-19, Argonne National Laboratory, Argonne, III., Oct.

Stork, K., 1994a, Analysis Memorandum: A Comparison of Fuel Ethanol Supply and Demand Due to RFG and Gasohol, sponsor report, Argonne National Laboratory, Argonne, Ill., Jan. 15.

Stork, K., 1994b, Analysis Memorandum: The Impact of the Renewable Oxygenate Proposal on Ethanol Availability for Use as an Oxygenate in RFG, Oxygenated Gasoline and Gasohol, sponsor report, Argonne National Laboratory, Argonne, Ill., June 6.

Turhollow, A.F., 1993, personal communication from Turhollow, Oak Ridge National Laboratory, Oak Ridge, Tenn., to M. Singh, Argonne National Laboratory, Argonne, Ill., May.

Turner, Mason \& Company, 1993, NPC Refining Study, IIC-Summer 1995/2000 F2-SF and 4/92 CF Case Runs, Dallas, Tex., Jan.

USDA, 1988, Ethanol: Economic and Policy Tradeoffs, Agricultural Economic Report 585, U.S. Department of Agriculture, Apr. 
APPENDIX A:

CHANGES RELATIVE TO EARLIER ARGONNE ANALYSES OF REFORMULATED GASOLINE AND THE RENEWABLE OXYGENATE STANDARD 


\section{APPENDIX A:}

\section{CHANGES RELATIVE TO EARLIER ARGONNE ANALYSES OF REFORMULATED GASOLINE AND THE RENEWABLE OXYGENATE STANDARD}

Many of the calculations presented in this report were used in earlier versions of the analysis presented here. However, substantial revisions were made in several of the newer versions. These changes were made to address the comments of peer reviewers, correct calculational errors, and update reference data. In this version of the analysis, total gasolineequivalent demand for transportation energy has been adjusted to make it consistent with energy requirements that the U.S. Department of Energy's Energy Information Administration (DOE/EIA) expects in 1995 for the first-year and near-term cases and in 2000 for the long-term case. For ethanol demand, $2.0 \mathrm{wt} \%$ oxygen ( $5.7 \mathrm{vol} \%$ ethanol) has been assumed. Although more ethanol may be used in a given batch of fuel, it would presumably be traded in the credit market, so aggregate demand for ethanol in reformulated gasoline (RFG) would be held to the volume required for $2.0 \mathrm{wt} \%$ oxygenation.

The focus of this version of the analysis has been shifted to the RFGs that are anticipated under the renewable oxygenate standard (ROS). This version considers the impact of the phase-in of the ROS. (Earlier versions were published before the promulgation of the ROS.)

Other changes in this analysis include the following:

- For this analysis of energy and greenhouse gas (GHG) emissions, winter hydrocarbons (HCs) are distinguished from summer HCs so the data correspond better with winter and summer model runs. Summer, year2000 HCs from a TM model run had been used for previous analyses of winter fuels as well as summer fuels.

- Denaturant energy is included for ethanol; an average value of $5 \mathrm{vol} \%$ denaturant is assumed.

- The volume percent of oxygenate that corresponds to a given weight percent of oxygen in a fuel is calculated for each of the three oxygenates on the basis of the formula published by the U.S. Environmental Protection Agency (EPA 1994b). Ethanol is assumed to be denatured $(5 \mathrm{vol} \% \mathrm{HC}$ ), and ethers are assumed to be pure. An average gravity of 58.5 API (degrees American Petroleum Institute) is assumed for finished fuel in this calculation.

- Volumes of ethanol used in federal oxygenated gasoline (OG) are estimated by state on the basis of EPA and Information Resources, Inc. (IRI) data. 
- The length of winter has been revised from 7 to 6.5 months to be consistent with the EPA's analysis.

- The front-loaded period has been shortened from 4 to 3 months because the EPA's regulatory impact analysis (RIA) uses January-March as the first part of its 197-day winter season (EPA 1994a, p. 9).

- Formerly, calculations of "current ethanol use" in RFG states included non-RFG areas. Thus, ethanol that was diverted from non-RFG areas to RFG areas within the same state was not considered to be diverted. The reasoning was that diverting ethanol from non-RFG areas to RFG areas within the same state would not overburden the ethanol transport system (because the change in destination involved such a small distance). Now, "current ethanol use" is only within RFG areas (no "free" diversion from in-state, non-RFG areas). This change was made to better reflect the EPA's intentions regarding diversion.

- RFG program participants as of the end of April 1995 are included in the demand calculations. Areas that opted out of as of April 1995 are excluded; they include all counties in Pennsylvania outside the Philadelphia Central Metropolitan Statistical Area (CMSA); Jefferson County in New York; the Albany and Buffalo CMSAs in New York; Hancock and Waldo Counties in Maine; and Kewaunee, Manitowoc, and Sheboygan Counties in Wisconsin. 
APPENDIX B:

SPREADSHEET OUTPUT ON REFORMULATED GASOLINE/ ETHANOL DEMAND 


\section{Maior Assumptions:}

Transportion energy demand is distributed in proportion to population.

Population fraction = fuel fraction

No price elasticity for fuel demand

No change in vehicle stock from 1993-1995

Califomia RFGs \& OG restricted to $2.0 \%$ wt oxygen max. NY max is $2.7 \%$ wt oxygen

Non-CA RFGs: $2.1 \%$ wt. oxygen (averaging standard or compliance margin for per-gallon refiner).

Non-CA OGs: $2.7 \%$ wt oxygen

Trade excess renewable oxygen credits.

\section{Reference Values:}

Historical national gasoline demand, 1992 (MM BbV/day):

YALUE BANGENAME

(1992 demand on 1993-adjusted basis. See Table B4, PSA 93)

7.376

Projected national gasoline demand, 1995 (MM 8bVday):

(from EIA STEO, August, 1994 (94/3Q). Table 7.)

Incremental gasoline demand ('92 to "95):

$3.78 \%$

INCR_DMD

(based on ElA data)

Noto:

EIA assumptions about energy densities of fuels differ slighty from those used in this analysis. Volumetric demands (historical and projected) from ElA have been used without adjustment because it is assumed that difference between LHVs is within plausible uncertainty bounds associated with this analysis.

RFG 1995 spillover (\%):

$1.00 \%$

SPILL

OG 1995 spillover (\%):

$1.00 \%$

SPILL_OG

Length of Winter-RFG period (months):

6.5 WIN_LENGTH

Length of Foreshortened Winter case (months):

3

SHORT_WIN

Average length of $O G$ for $\mathrm{CO}$ control (months): 
Eneroy Conversion Faclors

Lower Heating Values (LHVS) are used for energy content of fuels.

Energy content (Btw/gal) of HC fraction of gasolines (summer):

Energy content (Btw/gai) of HC fraction of gasolines (winter):

Energy content (Btu/gal) of ETBE:

Energy content (Btw/gal) of MTBE:

Energy content (Btwgal) of ethanol (pure):

Energy content (Btu/gal) of ethanol w/ $5 \%$ (avg.) denaturant (HCs):

Calculated multiplicative conversion factors:

(volume deila for equal energy delivery)

Gasohol to CG-a:

Gasoline w/ EtOH at 2.0\% wt oxygen to CG-eq:

Gasoline w/ EIOH at $2.1 \%$ wt oxygen to CG-eq:

Gasoline w/ EtOH at 2.7\% wt oxygen to CG-eq:

Gasoline w/MTBE at 2.0\% wt oxygen to CG-eq:

Gasoline w/ MTBE at 2.1\% wt oxygen to CG-eq:

Gasoline w/MTBE at $2.7 \%$ wt oxygen to CG-eq:

Gasoline w/ ETBE at 2.0\% wt oxygen to CG-eq:

Gasoline w/ ETBE at $2.1 \%$ wt oxygen to CG-eq:

Gasoline w/ ETBE at $2.7 \%$ wt oxygen to CG-eq:

NOTE: Divide by above factors for reciprocal conversions

Notes en conversion factors:

The weight-percentageNolume-percentage relationships for the various

RFGs are derived from a formula published by EPA on 9/26/94 in an RFG Q\&A update.

Denaturant in ethanol is assumed to be $5 \% \mathrm{HCs}$ (1.e., $10 \%$-vol EtOH provides $3.5 \%$-wt oxygen). MTBE and ETBE are assumed to be pure.

Your mileage may vary.

Oxygen. exycenate \& eneroy centent of RFG: (Average gravity: 58.5 deg. API)

$\begin{array}{crc}\text { Oxygun wt \% } & \text { Volume } \% & \text { Oxygenate } \\ 2.0 \% & 12.8 \% & \text { ETBE } \\ & 11.0 \% & \text { MTBE } \\ & 5.7 \% & \text { ETOH } \\ & 13.4 \% & \text { ETBE } \\ 2.1 \% & 11.6 \% & \text { MTBE } \\ & 6.0 \% & \text { ETOH } \\ & 17.2 \% & \text { ETBE } \\ 2.7 \% & 14.9 \% & \text { MTBE } \\ & 7.7 \% & \text { EtOH } \\ & 10.0 \% & \text { EtOH } \\ 3.5 \% & 2.0 \% & \text { MTBE }\end{array}$

NOTE: Conventional gasoline (CG) is assumed to contain $2 \%$ MTBE to enhance octane.
Eneroy delivery per gallon REG:

\begin{tabular}{|c|c|c|}
\hline $\begin{array}{r}\text { Summer } \\
\text { Btw/gallon } \\
112,253 \\
112,190 \\
112,316\end{array}$ & & $\begin{array}{r}\text { Winter } \\
\text { Btw/gallon } \\
110,683 \\
110,588 \\
110,619\end{array}$ \\
\hline $\begin{array}{l}112,141 \\
112,074 \\
112,322\end{array}$ & & $\begin{array}{l}110,582 \\
110,482 \\
110,515\end{array}$ \\
\hline $\begin{array}{l}111,467 \\
111,381 \\
111,699\end{array}$ & & $\begin{array}{l}109,977 \\
109,849 \\
109,890\end{array}$ \\
\hline 110,852 & (Gasohol) & 110,852 \\
\hline 114 & (1) & 112,316 \\
\hline
\end{tabular}

\begin{tabular}{|c|c|}
\hline WIS & TER \\
\hline & \\
\hline $\begin{array}{l}6965 \\
4887\end{array}$ & GHOLW \\
\hline .983960 & ETOH21W \\
\hline .978401 & ETOH27W \\
\hline 1.984613 & MTBE20W \\
\hline 33673 & MTBE21W \\
\hline & \\
\hline
\end{tabular}

VALUE BANGENAME

0.986965 GHOLW

0.983431 MTBE20

0.982418 MTBE21

0.976343 MTBE27

0.983988 ETBE20

0.977095 ETBE27

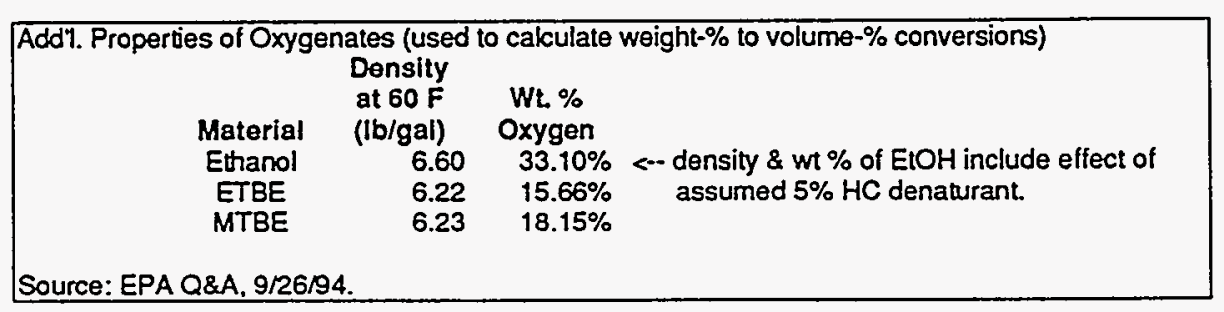




\begin{tabular}{|c|c|c|c|c|}
\hline state & $\begin{array}{c}995 \text { Fuel EtoH } \\
\text { Operational } \\
\text { Production } \\
\text { Capacity } \\
\text { (85\% of } \\
\text { Nameplate) }\end{array}$ & $\begin{array}{r}\text { Projected } 1995 \\
\text { Gasohol Demand } \\
\text { (w/o CAAA or CARB) }\end{array}$ & $\begin{array}{r}\text { Projected } 1995 \\
\text { Gasoline Demand } \\
\text { (w/o CAAA or CARB) }\end{array}$ & $\begin{array}{l}\text { Projected } 1995 \\
\text { Total Gasoline- } \\
\text { Equivalent Demand }\end{array}$ \\
\hline Alabama & 0.0 & 291.3 & $1,955.5$ & $2,241.0$ \\
\hline Alaska & 0.0 & 0.0 & 259.5 & 259.5 \\
\hline Arizona & 0.0 & 0.0 & $1,833.8$ & 1.833 .8 \\
\hline Arkansas & 0.0 & 25.5 & $1,272.4$ & $1,297.4$ \\
\hline Callfornta & 4.5 & 61.7 & $13,868.5$ & $13,929.0$ \\
\hline Colorado & 0.0 & 147.4 & $1,435.0$ & $1,579.4$ \\
\hline Connecticut & 0.0 & 52.3 & $1,387.2$ & $1,438.4$ \\
\hline Delaware & 0.0 & 0.0 & 358.0 & 358.0 \\
\hline Dist. of Col. & 0.0 & 0.0 & 177.6 & 177.6 \\
\hline Flortda & 0.0 & 89.5 & $6,230.5$ & $6,318.2$ \\
\hline Georgla & 0.0 & 23.8 & $3,679.3$ & $3,702.6$ \\
\hline Hawail & 0.0 & 0.0 & 391.4 & 391.4 \\
\hline Idaho & 6.0 & 45.7 & 482.4 & 527.2 \\
\hline Illinois & 597.1 & $1,626.4$ & $3,096.9$ & $4,690.7$ \\
\hline Indiana & 63.8 & 666.6 & $2,081.6$ & $2,734.9$ \\
\hline Iowa & 317.9 & 533.9 & 876.3 & $1,399.5$ \\
\hline Kansas & 29.7 & 65.4 & $1,163.6$ & $1,227.7$ \\
\hline Kentucky & 0.0 & 378.6 & $1,583.6$ & $1,954.7$ \\
\hline Loulstana & 0.0 & 86.8 & $1,905.9$ & $1,991.0$ \\
\hline Ma1ne & 0.0 & 0.0 & 623.2 & 623.2 \\
\hline Maryland & 0.0 & 0.0 & $2,164.3$ & $2,164.3$ \\
\hline Massachusetts & 0.0 & 0.0 & $2,446.3$ & $2,446.3$ \\
\hline Michigan & 0.0 & 534.3 & $3,949.8$ & $4,473.4$ \\
\hline Minnesota & 50.1 & 675.6 & $1,530.8$ & $2,192.9$ \\
\hline M1ssissippi & 0.0 & 0.0 & $1,347.5$ & $1,347.5$ \\
\hline M1ssouri & 0.0 & 262.6 & $2,622.6$ & $2,879.9$ \\
\hline Montana & 1.7 & 5.2 & 468.3 & 473.4 \\
\hline Nebraska & 156.0 & 385.9 & 414.0 & 792.2 \\
\hline Nevada & 0.0 & 74.4 & 634.9 & 707.8 \\
\hline New Hampshire & 0.0 & 0.0 & 534.4 & 534.4 \\
\hline New Jersey & 0.0 & 0.0 & $3,381.7$ & $3,381.7$ \\
\hline New Mexico & 10.2 & 112.7 & 747.1 & 857.5 \\
\hline New York & 0.0 & 0.0 & $5,695.4$ & $5,695.4$ \\
\hline N. Carolina & 0.0 & 30.4 & $3,377.0$ & $3,406.8$ \\
\hline N. Dakota & 33.2 & 57.9 & 306.6 & 363.3 \\
\hline Ohio & 55.3 & $1,296.3$ & $3,526.3$ & $4,796.6$ \\
\hline Oklahoma & 0.0 & 0.0 & $1,760.0$ & $1,760.0$ \\
\hline Oregon & 0.0 & 198.4 & $1,214.2$ & $1,408.6$ \\
\hline Pennsylvania & 0.0 & 0.0 & $4,739.7$ & $4,739.7$ \\
\hline Rhode Island & 0.0 & 0.0 & 386.4 & 386.4 \\
\hline s. Carolina & 0.0 & 0.0 & $1,903.3$ & $1,903.3$ \\
\hline s. Dakota & 5.1 & 165.5 & 250.2 & 412.4 \\
\hline Tennessee & 34.0 & 201.7 & $2,387.7$ & $2,585.4$ \\
\hline Texas & 0.0 & 257.2 & $8,604.0$ & $8,856.0$ \\
\hline Utah & 0.0 & 2.6 & 787.6 & 790.1 \\
\hline Vermont & 0.0 & 0.0 & 303.6 & 303.6 \\
\hline Virginia & 0.0 & 107.3 & $3,053.0$ & $3,158.2$ \\
\hline Washington & 3.6 & 438.8 & $2,005.7$ & $2,435.7$ \\
\hline West Virginia & 0.0 & 43.6 & 833.7 & 876.4 \\
\hline Wisconsin & 0.0 & 166.1 & $2,056.2$ & $2,219.0$ \\
\hline Wyoming & 0.0 & 53.6 & 275.3 & 327.8 \\
\hline Total & 1,368 & 9,165 & 108,370 & 117,351 \\
\hline
\end{tabular}

The tables in Appendix $B$ are in millions of gallons per year (MMGPY) and they are based on the assumption that that $30 \%$ of the $\mathrm{O}_{2}$ in RFG is derived from renewable oxygenates. 


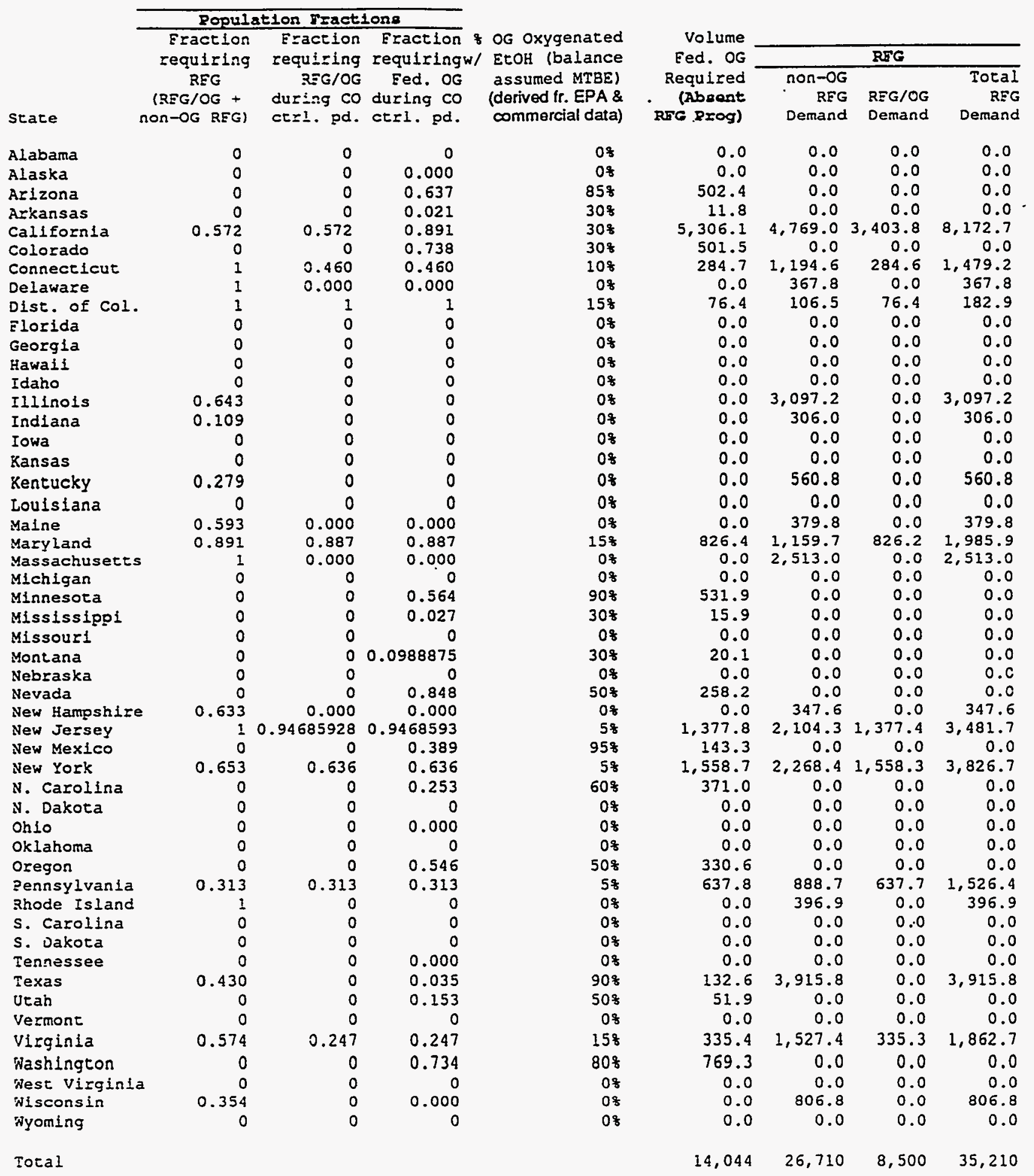




\begin{tabular}{|c|c|c|c|c|c|c|}
\hline state & $\begin{array}{r}\text { Fed. OG } \\
\text { Demand } \\
\text { (non-RFG } \\
\text { OG, net } \\
\text { gasohol) } \\
\text { ONDER ROS }\end{array}$ & $\begin{array}{r}\text { Gasohol } \\
\text { Demand } \\
\text { ONDER ROS }\end{array}$ & $\begin{array}{l}\text { CG Demand } \\
\text { ONDER ROS }\end{array}$ & $\begin{array}{l}\text { EtOH use } \\
\text { in gasohol } \\
\text { ABSENT REG }\end{array}$ & $\begin{array}{l}\text { EtOH use in } \\
\text { OG (net of } \\
\text { gasohol used } \\
\text { for CO ctrl) } \\
\text { ABSENT RFG }\end{array}$ & $\begin{array}{r}\text { Total } \\
\text { Non-RFG } \\
\text { Ethanol } \\
\text { Demand } \\
\text { (g'hol+OG) } \\
\text { ABSENT RFG }\end{array}$ \\
\hline Alabama & 0.0 & 291.3 & $1,955.5$ & 29.1 & 0.0 & 29.1 \\
\hline Alaska & 0.0 & 0.0 & 259.5 & 0.0 & 0.0 & 0.0 \\
\hline Arizona & 502.4 & 0.0 & $1,347.2$ & 0.0 & 31.8 & 31.8 \\
\hline Arkansas & 11.5 & 25.5 & $1,261.3$ & 2.5 & 0.2 & 2.8 \\
\hline California & $1,903.0$ & 0.0 & $4,111.0$ & 6.2 & 87.0 & 93.2 \\
\hline Colorado & 455.6 & 147.4 & 993.7 & 14.7 & 7.8 & 22.5 \\
\hline Connecticut & 0.0 & 0.0 & 0.0 & 5.2 & 1.4 & 6.6 \\
\hline Delaware & 0.0 & 0.0 & 0.0 & 0.0 & 0.0 & 0.0 \\
\hline Dist. of Col. & 0.0 & 0.0 & 0.0 & 0.0 & 0.9 & 0.9 \\
\hline Flortda & 0.0 & 89.5 & $6,230.5$ & 9.0 & 0.0 & 9.0 \\
\hline Georgla & 0.0 & 23.8 & $3,679.3$ & $2 . ' 4$ & 0.0 & 2.4 \\
\hline Hawa11 & 0.0 & 0.0 & 391.4 & 0.0 & 0.0 & 0.0 \\
\hline Idaho & 0.0 & 45.7 & 482.4 & 4.6 & 0.0 & 4.6 \\
\hline Illinols & 0.0 & 581.0 & $1,106.4$ & 162.6 & 0.0 & 162.6 \\
\hline Indiana & 0.0 & 594.0 & $1,854.9$ & 66.7 & 0.0 & 66.7 \\
\hline Iowa & 0.0 & 533.9 & 876.3 & 53.4 & 0.0 & 53.4 \\
\hline Kansas & 0.0 & 65.4 & $1,163.6$ & 6.5 & 0.0 & 6.5 \\
\hline Kentucky & 0.0 & 272.9 & $1,141.3$ & 37.9 & 0.0 & 37.9 \\
\hline Louisiana & 0.0 & 86.8 & $1,905.9$ & 8.7 & 0.0 & 8.7 \\
\hline Maine & 0.0 & 0.0 & 253.5 & 0.0 & 0.0 & 0.0 \\
\hline Maryland & 0.0 & 0.0 & 235.6 & 0.0 & 9.2 & 9.2 \\
\hline Massachusetts & 0.0 & 0.0 & 0.0 & 0.0 & 0.0 & 0.0 \\
\hline Mich1gan & 0.0 & 534.3 & $3,949.8$ & 53.4 & 0.0 & 53.4 \\
\hline Mirinesota & 371.3 & 675.6 & $1,171.1$ & 67.6 & 23.7 & 91.2 \\
\hline M1ss1ss1pp1 & 15.9 & 0.0 & $1,332.1$ & 0.0 & 0.4 & 0.4 \\
\hline M1ssour1 & 0.0 & 262.6 & $2,622.6$ & 26.3 & 0.0 & 26.3 \\
\hline Montana & 19.9 & 5.2 & 449.0 & 0.5 & 0.4 & 1.0 \\
\hline Nebiaska & 0.0 & 385.9 & 414.0 & 38.6 & 0.0 & 38.6 \\
\hline Nevada & 231.6 & 74.4 & 410.6 & 7.4 & 7.6 & 15.1 \\
\hline New Hampshire & 0.0 & 0.0 & 196.0 & 0.0 & 0.0 & 0.0 \\
\hline New Jersey & 0.0 & 0.0 & 0.0 & 0.0 & 5.1 & 5.1 \\
\hline New Mexico & 124.9 & 112.7 & 626.1 & 11.3 & 8.8 & 20.0 \\
\hline New York & 0.0 & 0.0 & $1,978.8$ & 0.0 & 5.8 & 5.8 \\
\hline N. Carolina & 367.7 & 30.4 & $3,020.9$ & .3 .0 & 16.3 & 19.4 \\
\hline N. Dakota & 0.0 & 57.9 & 306.6 & 5.8 & 0.0 & 5.8 \\
\hline Oh10 & 0.0 & $1,296.3$ & $3,526.3$ & 129.6 & 0.0 & 129.6 \\
\hline Oklahoma & 0.0 & 0.0 & $1,760.0$ & 0.0 & 0.0 & 0.0 \\
\hline Oregon & 284.9 & 198.4 & 938.2 & 19.8 & 8.9 & 28.7 \\
\hline Pennsylvania & 0.0 & 0.0 & $3,257.3$ & 0.0 & 2.4 & 2.4 \\
\hline Rhode Island & 0.0 & 0.0 & 0.0 & 0.0 & 0.0 & 0.0 \\
\hline s. Carolina & 0.0 & 0.0 & $1,903.3$ & 0.0 & 0.0 & 0.0 \\
\hline S. Dakota & 0.0 & 165.5 & 250.2 & 16.6 & 0.0 & 16.6 \\
\hline Tennessee & 0.0 & 201.7 & $2,387.7$ & 20.2 & 0.0 & 20.2 \\
\hline Texas & 130.5 & 146.5 & 4.774 .2 & 25.7 & 8.6 & 34.3 \\
\hline Utah & 51.7 & 2.6 & 737.5 & 0.3 & 1.9 & 2.2 \\
\hline Vermont & 0.0 & 0.0 & 303.6 & 0.0 & 0.0 & 0.0 \\
\hline Virginia & 0.0 & 45.8 & $1,301.9$ & 10.7 & 2.9 & 13.6 \\
\hline Washington & 633.5 & 438.8 & $1,392.1$ & 43.9 & 35.7 & 79.5 \\
\hline West VIxgInie & 0.0 & 43.6 & 833.7 & 4.4 & 0.0 & 4.4 \\
\hline Wisconsin & 0.0 & 107.3 & $1,328.5$ & 16.6 & 0.0 & 16.6 \\
\hline Wyoming & 0.0 & 53.6 & 275.3 & 5.4 & 0.0 & 5.4 \\
\hline Total & 5,104 & 7,596 & 70,697 & 916 & 267 & 1,183 \\
\hline
\end{tabular}




\begin{tabular}{|c|c|c|c|c|c|}
\hline State & $\begin{array}{r}\text { Etor use in } \\
\text { gasohol w/In } \\
\text { RFG areas } \\
\text { ABSENT RFG }\end{array}$ & $\begin{array}{r}\text { EtOH use in } \\
\text { Fed.OG W/in } \\
\text { REG areas } \\
\text { ABSENT RFG }\end{array}$ & $\begin{array}{l}\text { Total EtoH } \\
\text { use within } \\
\text { RFG areasmi } \\
\text { ABSENT RFGin }\end{array}$ & $\begin{array}{l}\text { nimum Eton use } \\
\text { RFG due to RO }\end{array}$ & $\begin{array}{l}\text { EtOH under } \\
\text { ROS (vs, no } \\
\text { ROS) in RFG } \\
\text { areas only }\end{array}$ \\
\hline Alabama & 0.0 & 0.0 & 0.0 & 0.0 & 0.0 \\
\hline Alaska & 0.0 & 0.0 & 0.0 & 0.0 & 0.0 \\
\hline Arizona & 0.0 & 0.0 & 0.0 & 0.0 & 0.0 \\
\hline Arkansas & 0.0 & 0.0 & 0.0 & 0.0 & 0.0 \\
\hline California & 3.5 & 49.7 & 53.3 & 139.4 & $(86.2)$ \\
\hline Colorado & 0.0 & 0.0 & 0.0 & 0.0 & 0.0 \\
\hline Connecticut & 5.2 & 0.6 & 5.9 & 25.2 & (19.4) \\
\hline Delaware & 0.0 & 0.0 & 0.0 & 6.3 & $(6.3)$ \\
\hline Dist. of col. & 0.0 & 0.9 & 0.9 & 3.1 & $(2.3)$ \\
\hline Florida & 0.0 & 0.0 & 0.0 & 0.0 & 0.0 \\
\hline Georgia & 0.0 & 0.0 & 0.0 & 0.0 & 0.0 \\
\hline Hawa11 & 0.0 & 0.0 & 0.0 & 0.0 & 0.0 \\
\hline Idabo & 0.0 & 0.0 & 0.0 & 0.0 & 0.0 \\
\hline IIlinols & 104.5 & 0.0 & 104.5 & 52.8 & 51.7 \\
\hline Indlana & 7.3 & 0.0 & 7.3 & 5.2 & 2.0 \\
\hline Iowa & 0.0 & 0.0 & 0.0 & 0.0 & 0.0 \\
\hline Kansas & 0.0 & 0.0 & 0.0 & 0.0 & 0.0 \\
\hline Kentucky & 10.6 & 0.0 & 10.6 & 9.6 & 1.0 \\
\hline Iouisiana & 0.0 & 0.0 & 0.0 & 0.0 & 0.0 \\
\hline Maine & 0.0 & 0.0 & 0.0 & 6.5 & $(6.5)$ \\
\hline Maryland & 0.0 & 8.2 & 8.2 & 33.9 & $(25.7)$ \\
\hline Massachusetts & 0.0 & 0.0 & 0.0 & 42.9 & $(42.9)$ \\
\hline Michigan & 0.0 & 0.0 & 0.0 & 0.0 & 0.0 \\
\hline Minnesota & 0.0 & 0.0 & 0.0 & 0.0 & 0.0 \\
\hline Mississippi & 0.0 & 0.0 & 0.0 & 0.0 & 0.0 \\
\hline Missouri & 0.0 & 0.0 & 0.0 & 0.0 & 0.0 \\
\hline Montana & 0.0 & 0.0 & 0.0 & 0.0 & 0.0 \\
\hline Nebraska & 0.0 & 0.0 & 0.0 & 0.0 & 0.0 \\
\hline Nevada & 0.0 & 0.0 & 0.0 & 0.0 & 0.0 \\
\hline New Hampshire & 0.0 & 0.0 & 0.0 & 5.9 & $(5.9)$ \\
\hline New Jersey & 0.0 & 4.8 & 4.8 & 59.4 & $(54.6)$ \\
\hline New Mexico & 0.0 & 0.0 & 0.0 & 0.0 & 0.0 \\
\hline New York & 0.0 & 3.7 & 3.7 & 65.3 & $(61.6)$ \\
\hline N. Carolina & 0.0 & 0.0 & 0.0 & 0.0 & 0.0 \\
\hline N. Dakota & 0.0 & 0.0 & 0.0 & 0.0 & 0.0 \\
\hline Ohio & 0.0 & 0.0 & 0.0 & 0.0 & 0.0 \\
\hline Oklahoma & 0.0 & 0.0 & 0.0 & 0.0 & 0.0 \\
\hline Oregon & 0.0 & 0.0 & 0.0 & 0.0 & 0.0 \\
\hline Pennsylvania & 0.0 & 0.7 & 0.7 & 26.0 & $(25.3)$ \\
\hline Rhode Island & 0.0 & 0.0 & 0.0 & 6.8 & $(6.8)$ \\
\hline s. Carolina & 0.0 & 0.0 & 0.0 & 0.0 & 0.0 \\
\hline s. Dakota & 0.0 & 0.0 & 0.0 & 0.0 & 0.0 \\
\hline Tennessee & 0.0 & 0.0 & 0.0 & 0.0 & 0.0 \\
\hline Texas & 11.1 & 0.0 & 11.1 & 66.8 & $(55.7)$ \\
\hline Utah & 0.0 & 0.0 & 0.0 & 0.0 & 0.0 \\
\hline Vermont & 0.0 & 0.0 & 0.0 & 0.0 & 0.0 \\
\hline Virginia & 6.2 & 0.7 & 6.9 & 31.8 & $(24.9)$ \\
\hline Washington & 0.0 & 0.0 & 0.0 & 0.0 & 0.0 \\
\hline West Virginie & 0.0 & 0.0 & 0.0 & 0.0 & 0.0 \\
\hline Wisconsin & 5.9 & 0.0 & 5.9 & 13.8 & $(7.9)$ \\
\hline Wyoming & 0.0 & 0.0 & 0.0 & 0.0 & 0.0 \\
\hline Total & 154 & 69 & 224 & 601 & (377) \\
\hline
\end{tabular}




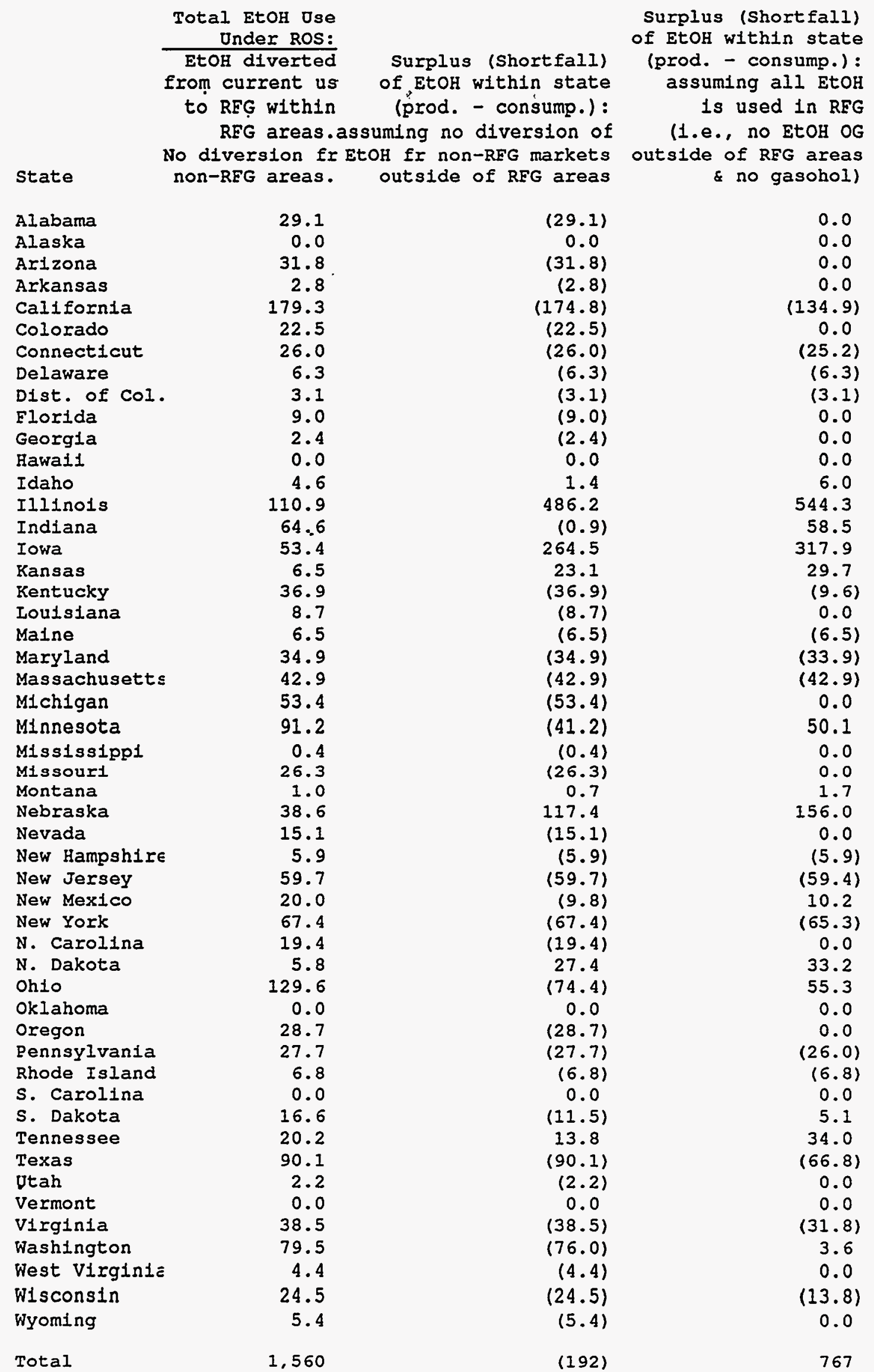


Annualized athanol utilization rato implied by satisfying Ros over period:

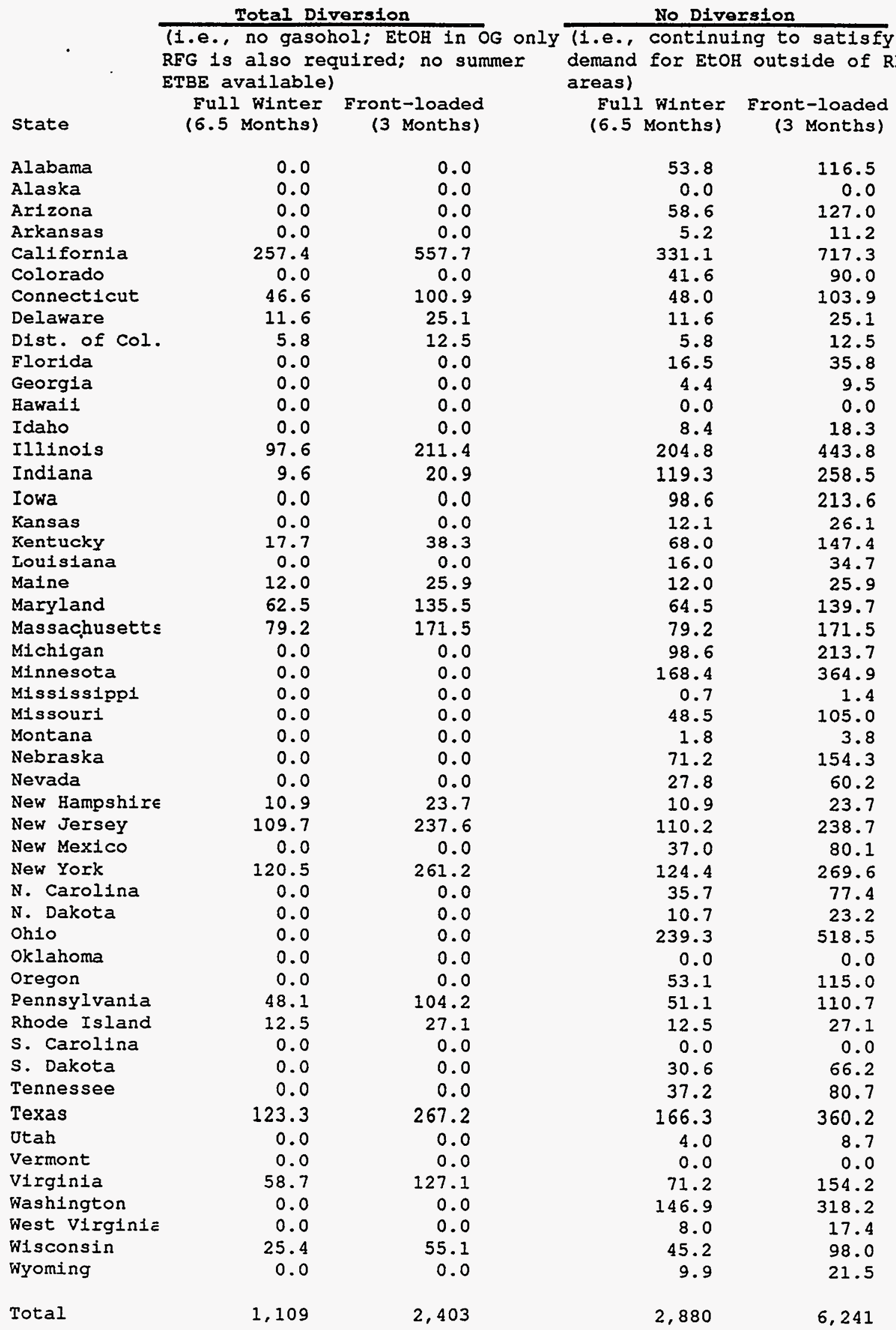


Base RFG (a11 MTBE-esygenated):

\begin{tabular}{|c|c|c|c|c|}
\hline & $\begin{array}{r}\text { Base } \\
\text { Summer } \\
\text { REG } \\
\text { Demand }\end{array}$ & $\begin{array}{r}\text { Base } \\
\text { Winter } \\
\text { Non-OG RFG } \\
\text { Demand }\end{array}$ & $\begin{array}{r}\text { Base } \\
\text { Winter } \\
\text { REG/OG } \\
\text { Demand }\end{array}$ & Total Base \\
\hline state & $(2.18$ Oxy.) & $(2.18$ Oxy.) & $(2.780 x y)$. & REG Demand \\
\hline Alabama & 0.0 & 0.0 & 0.0 & 0.0 \\
\hline Alaska & 0.0 & 0.0 & 0.0 & 0.0 \\
\hline Artzona & 0.0 & 0.0 & 0.0 & 0.0 \\
\hline Arkansas & 0.0 & 0.0 & 0.0 & 0.0 \\
\hline California & $3,748.1$ & 1.021 .0 & $3,403.3$ & $8,172.4$ \\
\hline Colorado & 0.0 & 0.0 & 0.0 & 0.0 \\
\hline Connecticut & 677.8 & 516.9 & 284.7 & $1,479.4$ \\
\hline Delaware & 168.7 & 199.1 & 0.0 & 367.8 \\
\hline Dist. of col. & 83.7 & 22.8 & 76.4 & 182.9 \\
\hline Florida & 0.0 & 0.0 & 0.0 & 0.0 \\
\hline Georg1a & 0.0 & 0.0 & 0.0 & 0.0 \\
\hline Hawa11 & 0.0 & 0.0 & 0.0 & 0.0 \\
\hline Idaho & 0.0 & 0.0 & 0.0 & 0.0 \\
\hline Illinots & $1,420.7$ & $1,676.8$ & 0.0 & $3,097.5$ \\
\hline Indiana & 140.4 & 165.7 & 0.0 & 306.0 \\
\hline Iowa & 0.0 & 0.0 & 0.0 & 0.0 \\
\hline Kansas & 0.0 & 0.0 & 0.0 & 0.0 \\
\hline Kentucky & 257.2 & 303.6 & 0.0 & 560.9 \\
\hline Loulsiaña & 0.0 & 0.0 & 0.0 & 0.0 \\
\hline Malne & 174.2 & 205.6 & 0.0 & 379.8 \\
\hline Maryland & 908.8 & 251.0 & 826.4 & $1,986.2$ \\
\hline Massachusetts & $1,152.7$ & $1,360.6$ & 0.0 & $2,513.3$ \\
\hline Michigan & 0.0 & 0.0 & 0.0 & 0.0 \\
\hline Minnesota & 0.0 & 0.0 & 0.0 & 0.0 \\
\hline M1ss1ss1ppi & 0.0 & 0.0 & 0.0 & 0.0 \\
\hline M1ssouri & 0.0 & 0.0 & 0.0 & 0.0 \\
\hline Montana & 0.0 & 0.0 & 0.0 & 0.0 \\
\hline Nebraska & 0.0 & 0.0 & 0.0 & 0.0 \\
\hline Nevada & 0.0 & 0.0 & 0.0 & 0.0 \\
\hline New Hampsh1re & 159.4 & 188.2 & 0.0 & 347.6 \\
\hline New Jersey & $1,593.5$ & 510.9 & $1,377.8$ & $3,482.2$ \\
\hline New Mexico & 0.0 & 0.0 & 0.0 & 0.0 \\
\hline New York & $1,751.3$ & 517.2 & $1,558.8$ & $3,827.3$ \\
\hline N. Carolina & 0.0 & 0.0 & 0.0 & 0.0 \\
\hline N. Dakota & 0.0 & 0.0 & 0.0 & 0.0 \\
\hline Oh10 & 0.0 & 0.0 & 0.0 & 0.0 \\
\hline Oklahoma & 0.0 & 0.0 & 0.0 & 0.0 \\
\hline Oregon & 0.0 & 0.0 & 0.0 & 0.0 \\
\hline Pennsylvania & 698.5 & 190.3 & 637.9 & $1,526.6$ \\
\hline Rhode Island & 182.0 & 214.9 & 0.0 & 396.9 \\
\hline s. Carolina & 0.0 & 0.0 & 0.0 & 0.0 \\
\hline S. Dakota & 0.0 & 0.0 & 0.0 & 0.0 \\
\hline Tennessee & 0.0 & 0.0 & 0.0 & 0.0 \\
\hline Tex $\neq s$ & $1,796.1$ & $2,120.0$ & 0.0 & $3,916.2$ \\
\hline Utalı & 0.0 & 0.0 & 0.0 & 0.0 \\
\hline Vermont & 0.0 & 0.0 & 0.0 & 0.0 \\
\hline Virginia & 853.5 & 674.0 & 335.4 & $1,862.9$ \\
\hline Washington & 0.0 & 0.0 & 0.0 & 0.0 \\
\hline West Virginia & 0.0 & 0.0 & 0.0 & 0.0 \\
\hline Wisconsin & 370.1 & 436.8 & 0.0 & 806.8 \\
\hline Wyoming & 0.0 & 0.0 & 0.0 & 0.0 \\
\hline rotal & 16,137 & 10,575 & 8,501 & 35,213 \\
\hline
\end{tabular}




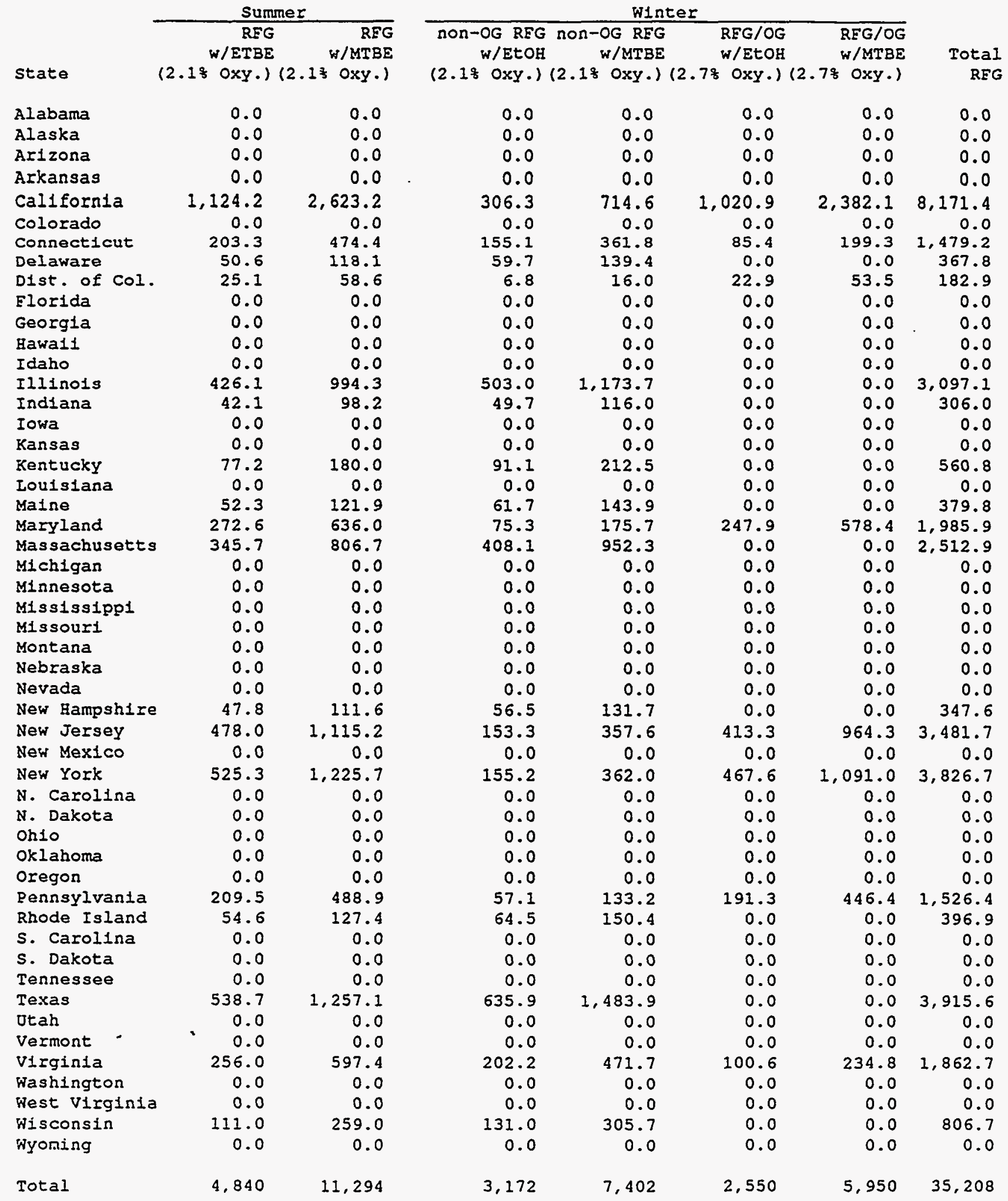


1991 Populatlons from 1993 Stat Abst, Tables 31 \& 42 and Appendlx II.

Populations covered by RFG program are based on Opt-In as of June 1, 1994, less opt outs of lato 1994 and early 1995.

OG population based on participation in the OG program during the 1993-1994 winter season.

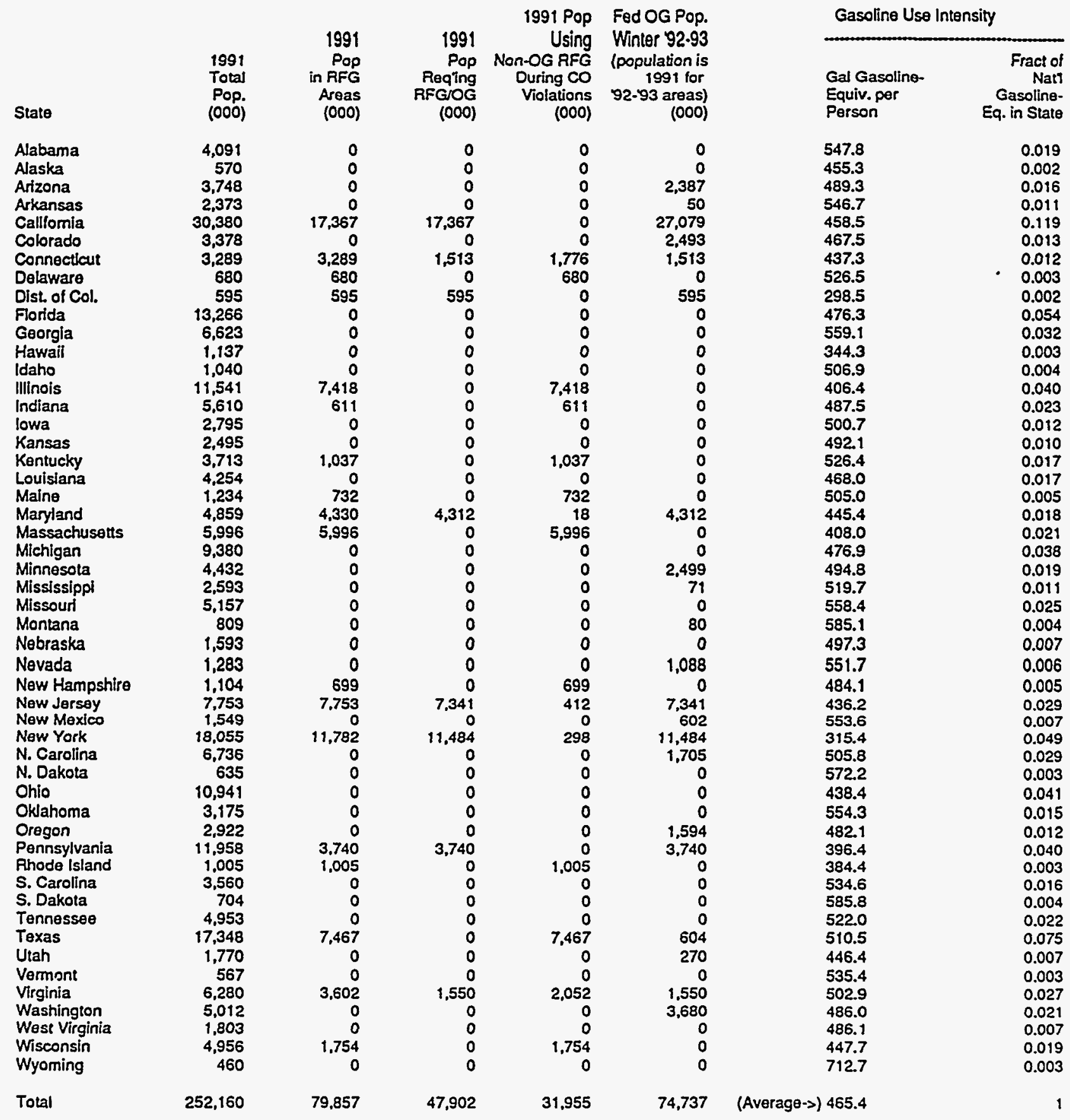


APPENDIX C:

SUMMER REFORMULATED GASOLINE MODEL RUNS (TM) 
TABLE C.1 Refining Raw Material and Product Rate - MBPCD III C Summer 1995/2000 F2 - SF and 4/92 CF Case Results, NPC 1991-92 Study of U.S. Refining Industry

\begin{tabular}{|c|c|c|c|c|c|c|}
\hline$\underset{\text { Raw }}{\text { Ratorialo }}$ & $\begin{array}{c}\text { Bam } \\
\text { Cas } Q 9 \\
\text { No FCANA }\end{array}$ & $\begin{array}{l}\text { Cases5 } \\
\text { 95 Full } \\
\text { Opt in }\end{array}$ & $\begin{array}{l}\text { Base Caso } \\
\text { Q6 Target } \\
\text { A V.O.C }\end{array}$ & $\begin{array}{c}\text { Cass S8 } \\
Q 6+ \\
1005 \text { RFG }\end{array}$ & $\begin{array}{c}\text { Caso } \\
\text { S6+ } \\
\text { Hi EtOH }\end{array}$ & $\begin{array}{l}\text { Coss S13H } \\
\text { S13+ } \\
\text { S6 } \Delta \text { Y.o.c. }\end{array}$ \\
\hline \multicolumn{7}{|l|}{ Raw Materials } \\
\hline Domentic - $\mathbf{S}$ & 1,223 & 1,2203 & 1,985 & 1,985 & 1,985 & 1,985 \\
\hline & 371 & 371 & 174 & 174 & 174 & 174 \\
\hline HH & 228 & 225 & 692 & 692 & 692 & 692 \\
\hline Poralgn - $\mathrm{s}$ & 259 & 278 & 732 & 732 & 732 & 780 \\
\hline HL & 166 & 172 & 669 & 669 & 669 & 669 \\
\hline НH & 1,752 & 632 & 1,531 & 1,500 & 1,517 & 1,385 \\
\hline Subtotal Crudes & $\overline{2,997}$ & $\overline{2,902}$ & $\overline{2,932}$ & $\overline{2,826}$ & $\overline{2,863}$ & $\overline{2,904}$ \\
\hline $\begin{array}{l}\text { MTBE } \\
\text { Etbunool }\end{array}$ & 10 & 88 & 100 & 184 & $\begin{array}{r}127 \\
30\end{array}$ & $\begin{array}{r}139 \\
30\end{array}$ \\
\hline Normal Buteno & i7 & 10 & & & & \\
\hline Inobutape & 22 & 33 & 36 & 40 & 49 & 53 \\
\hline Natural Gax to ti2 Pleat Pood & 5 & 5 & 5 & 5 & 11 & 5 \\
\hline Mothenol & $\mathbf{8}$ & 8 & 4 & 5 & 5 & 1 \\
\hline Otber Raw Materiala & 102 & 102 & 102 & 102 & 102 & 102 \\
\hline Total Raw Materials & $\overline{3,162}$ & $\overline{3,148}$ & $\overrightarrow{3,178}$ & $\overline{3,163}$ & $\overline{3,187}$ & $\overline{3,234}$ \\
\hline \multirow{2}{*}{\multicolumn{7}{|c|}{ Producte }} \\
\hline & & & & & & \\
\hline $\begin{array}{l}\text { Conventlonal } \\
\text { Oxygenated } \\
\text { Reformulatod Oxygenated }\end{array}$ & 1,682 & 760 & 752 & & & \\
\hline $\begin{array}{l}\text { Reformulated } \\
\text { CARB2 }\end{array}$ & & 960 & 945 & 1,713 & $\begin{array}{r}1,198 \\
514\end{array}$ & 1,205 \\
\hline $\begin{array}{l}\text { Koro JeL/Keraseno } \\
\text { Diesel/Na. } 2 \text { Pusals } \\
\text { Diezel - LA, ULS }\end{array}$ & 205 & 205 & 205 & 205 & 205 & 205 \\
\hline Diesel $-0.05 \% \mathrm{~S}$ & 580 & 580 & 580 & 580 & 580 & 580 \\
\hline No. 2 Puel & 102 & 102 & 102 & 102 & 102 & 102 \\
\hline No. 6. Fuel (1\% Sul) & 14 & 14 & 14 & 14 & 14 & 14 \\
\hline No. 6 Buaker & 11 & 11 & 11 & 11 & 11 & 38 \\
\hline Markatable Coke - 400 & $\mathbf{6 0}$ & 54 & 59 & 52 & 55 & 61 \\
\hline $\begin{array}{l}\text { Catalytic Coke - } 400 \\
\text { Vacuum Gas Oil }\end{array}$ & 52 & 50 & 50 & 49 & 50 & 50 \\
\hline Benzeas & 2 & 2 & 2 & 2 & 2 & 2 \\
\hline Toluene & 5 & 5 & 5 & 5 & 5 & 3 \\
\hline \multicolumn{7}{|l|}{$\begin{array}{l}\text { Heavy Aromatic Gaso } \\
\text { Pentroes to P/C }\end{array}$} \\
\hline Natural Gesolloe to P/C & 38 & 38 & 38 & 36 & 37 & 39 \\
\hline $\begin{array}{l}\text { Normal Butene } \\
\text { Inobutano }\end{array}$ & & & $2 s$ & 25 & 30 & 34 \\
\hline Propano & 98 & 92 & 94 & 88 & 90 & 92 \\
\hline Procos GavC2/C2, FOB & 162 & 138 & 144 & 120 & 132 & 135 \\
\hline Otber Product & 271 & 271 & 271 & 271 & 271 & 271 \\
\hline (Gala)/Los & $(120)$ & (114) & (118) & $(107)$ & $(109)$ & (108) \\
\hline Total Products & $\overline{3,162}$ & $\overline{3,148}$ & $\overline{3.178}$ & $\overline{3.163}$ & $\overline{3,187}$ & $\overline{3,234}$ \\
\hline \multicolumn{7}{|l|}{ Crude Properitos } \\
\hline Gravity, API & 33.9 & 34.2 & 34.1 & 34.3 & 34.2 & 34.2 \\
\hline Sulfur, Wts & 1.18 & 1.11 & 1.14 & 1.09 & 1.11 & 1.13 \\
\hline \multicolumn{7}{|l|}{ Gasoline Demand Inerease, $\$$} \\
\hline Results & & 1.1 & 0.9 & 1.8 & 1.8 & 21 \\
\hline Target & & 1.1 & 0.8 & 1.9 & 1.9 & 21 \\
\hline
\end{tabular}

(1) To maiotaia coostant miles traveled with lower BTU content reformulated gasolino.

Sourco: Turner, Mason, and Co., NPC Reaning Study (Table F-3, Jan 8, 1993, draß). 
TABLE C.2 Energy Balance Impacts of Ethanol at Constant $\triangle$ VOC - PADD II Summer 2000 Cases S13H vs S6[1] NPC 1991-93 Study of U.S. Refining Industry

\begin{tabular}{|c|c|c|c|c|c|}
\hline \multirow{2}{*}{ - } & \multicolumn{3}{|c|}{ MBPCD } & \multirow{2}{*}{$\begin{array}{l}\text { BEOEJ } \\
\text { Iiq } \mathrm{B}\end{array}$} & \multirow{2}{*}{$\begin{array}{c}\text { MBPCD } \\
\text { EOE }\end{array}$} \\
\hline & S6 & S13H & $\Delta$ & & \\
\hline $\begin{array}{l}\text { Products } \\
\text { Gasolines } \\
\text { RFG-E } \\
\text { RFGM }\end{array}$ & $1,712.7$ & $\begin{array}{r}512.0 \\
1,204.7\end{array}$ & $\begin{array}{r}512.0 \\
(508.0)\end{array}$ & $\begin{array}{l}0.746 \\
0.752\end{array}$ & $\begin{array}{r}382.0 \\
(382.0)\end{array}$ \\
\hline Subtotal & $1,712.7$ & $\overline{1,716.7}$ & $\overline{4.0}$ & & $\overline{0.0}$ \\
\hline $\begin{array}{l}\text { Bunker } \\
\text { Marketable Coke, FOE } \\
\text { Petrochem. Gaso. } \\
\text { Toluene } \\
\text { NC4 } \\
\text { Propane } \\
\text { Plant Fuel Burned, FOE } \\
\text { Loss (Gain) } \\
\text { Other }\end{array}$ & $\begin{array}{r}11.0 \\
51.8 \\
32.1 \\
5.0 \\
24.9 \\
80.0 \\
185.5 \\
(104.4) \\
1,164.6\end{array}$ & $\begin{array}{r}37.8 \\
61.1 \\
35.2 \\
3.0 \\
33.7 \\
86.0 \\
200.7 \\
(105.2) \\
1,164.6\end{array}$ & $\begin{array}{r}26.8 \\
9.3 \\
3.1 \\
(2.0) \\
8.8 \\
6.0 \\
15.2 \\
(0.8) \\
0.0\end{array}$ & $\begin{array}{l}1.00 \\
1.00 \\
0.69 \\
0.84 \\
0.68 \\
0.60 \\
1.00\end{array}$ & $\begin{array}{r}26.8 \\
9.3 \\
2.1 \\
(1.7) \\
6.0 \\
3.6 \\
15.2 \\
0.0 \\
0.0\end{array}$ \\
\hline Total & $\overline{3,163.2}$ & $\overline{3,233.6}$ & $\overline{70.4}$ & & 61.3 \\
\hline $\begin{array}{l}\text { Raw Materials } \\
\text { Crude } \\
\text { IC4 } \\
\text { MTBE } \\
\text { Methanol } \\
\text { Ethanol } \\
\text { Nat. Gas to H2 Plant } \\
\text { Other }\end{array}$ & $\begin{array}{r}2,826.4 \\
40.4 \\
184.3 \\
5.4 \\
\\
5.1 \\
102.0\end{array}$ & $\begin{array}{r}2,904.4 \\
53.2 \\
138.8 \\
0.6 \\
29.4 \\
5.2 \\
102.0\end{array}$ & $\begin{array}{r}78.0 \\
13.2 \\
(45.5) \\
(4.8) \\
29.4 \\
0.1 \\
0.0\end{array}$ & $\begin{array}{l}0.92 \\
0.65 \\
0.62 \\
0.62 \\
0.38 \\
0.51 \\
1.00\end{array}$ & $\begin{array}{r}71.8 \\
8.6 \\
(28.2) \\
(1.8) \\
15.0 \\
0.1 \\
0.0\end{array}$ \\
\hline Total & $3,163.2$ & $3,233.6$ & 70.4 & & 65.5 \\
\hline Net Inputs (Raw Mat less Prod) & & & & & 4.2 \\
\hline $\begin{array}{l}\text { Utilities } \\
\text { Nat. Gas Purch, FOE } \\
\text { Elec, MMKWh/d } \\
\text { Plant Fuel Burned, FOE }\end{array}$ & $\begin{array}{l}68.2 \\
23.3\end{array}$ & $\begin{array}{l}70.9 \\
25.9\end{array}$ & $\begin{array}{l}2.7 \\
2.6\end{array}$ & $\begin{array}{l}1.00 \\
1.60\end{array}$ & $\begin{array}{r}2.7 \\
4.2 \\
15.2\end{array}$ \\
\hline Total Utilities Used & & & & & 22.1 \\
\hline $\begin{array}{l}\text { Lost Energy } \\
\text { Total Net Inputs plus Utilities, FOE } \\
\text { Percent of Energy in Gasolines [2] } \\
\text { Percent of Energy in Ethanol [3] }\end{array}$ & & & & & $\begin{array}{r}26.3 \\
6.9 \% \\
175 \%\end{array}$ \\
\hline
\end{tabular}

(1) S13H VOC Reduction $=41 \%$ based on 4/92 EPA CF. Gasoline pool $=30 \%$ RFG.E $+70 \%$ RFG.M S6 VOC Reduction $=41 \%$ based on $4 / 92$ EPA CF. Gasoline pool $=100 \%$ RFG-M.

[2] 26.3 MBPCD FOE lost/382 MBPCD FOE in gasoline switched from RFG-M to RFG-E.

[3] 26.3 MBPCD FOE lost/15 MBPCD FOE in Ethanol used.

Source: Turner, Mason, and Co., NPC Refining Study (Table Y-1, March 30, 1993, draft). 
TABLE C.3 Run Basis and Reformulated Gasoline Pool Properties IIIC - Summer 2000 F2 - 4/92 CF Case Results NPC 1991-92 Study of U.S. Refining Industry

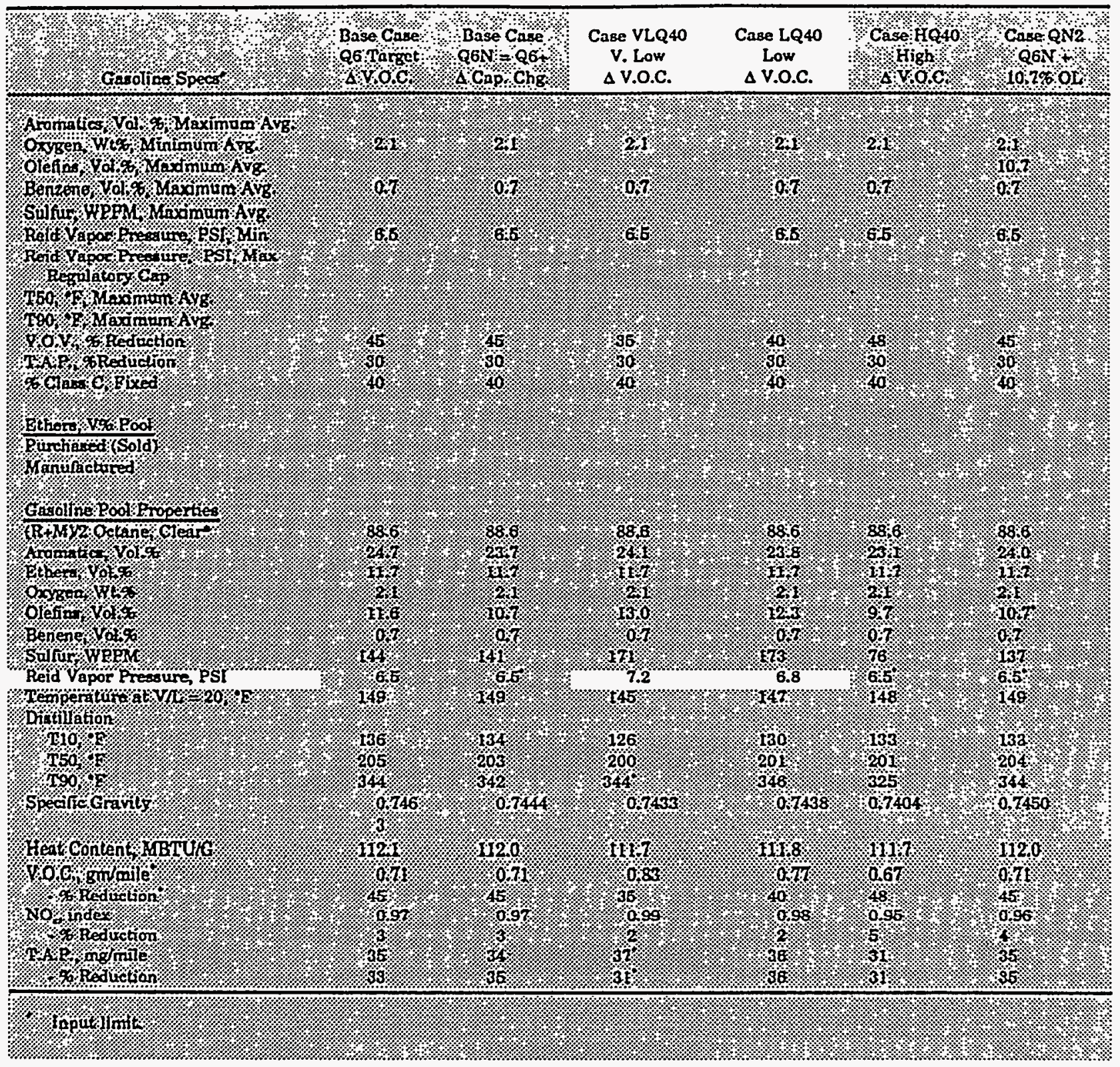

Source: Turner, Mason, and Co. (Table DI-1A, 1993). 
TABLE C.4 Refining Raw Material and Product Rates - MBPCD IIIC - Summer 2000 F2 - 4/92 CF Case Results, NPC 1991-92 Study of U.S. Refining Industry

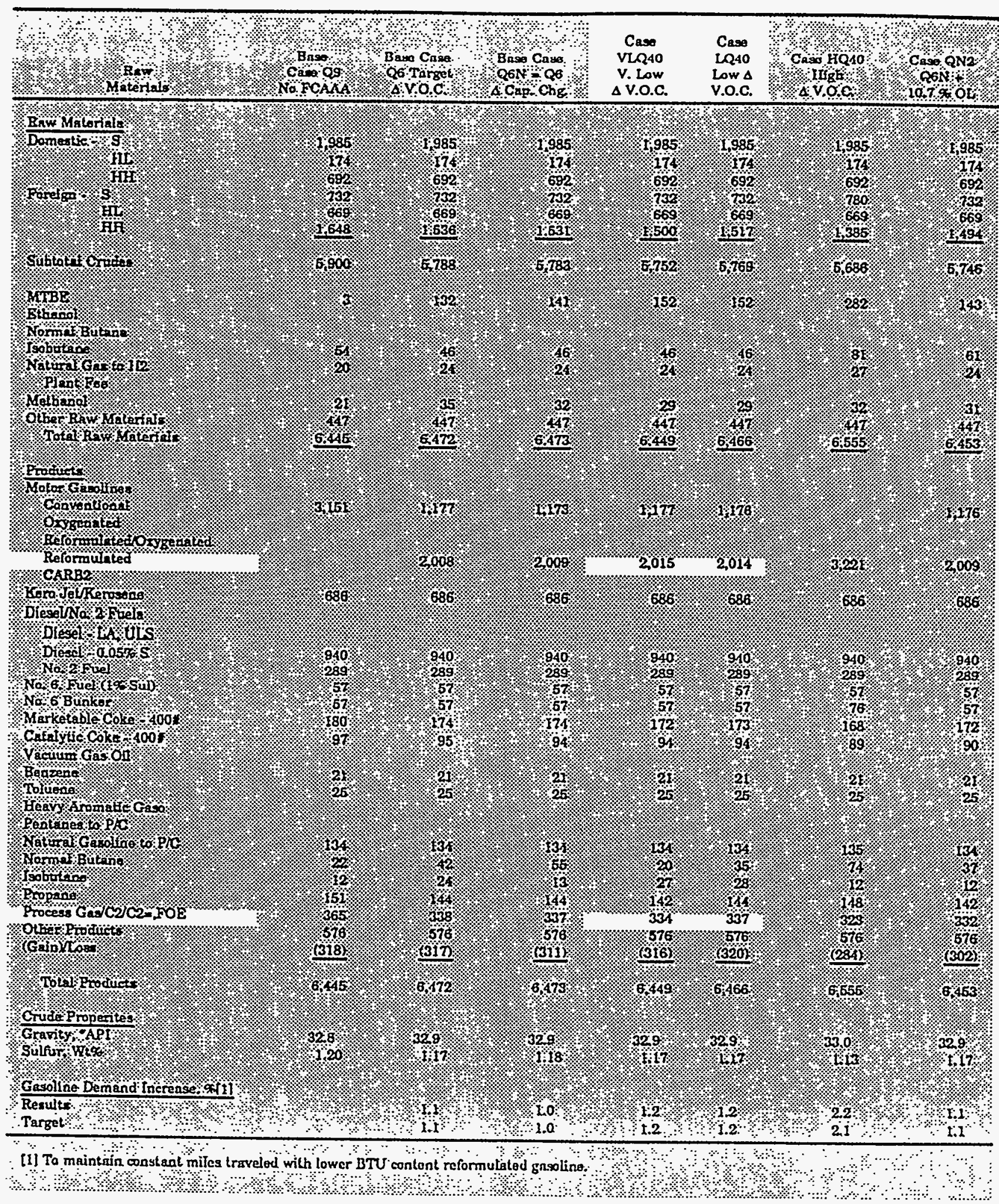

Sourea: Turaer, Mason, and Co. (Table D1-3, 1993). 
APPENDIX D:

WINTER REFORMULATED GASOLINE MODEL RUNS (TM AND ORNL) 
TABLE D.1 Energy Balance Impacts of Reformulated Gasoline PADD II

Winter 2000 Case Q9W Versus Case Q6W [1] API Study of Refining Economics

Beoducil:

Molor Gudines

Conventional

Oxyountind

Oryipra

RFO

Toual Moror Gasoline

Avtatlon Gerount

$\operatorname{Jax} A$

No. 2 Fual

No. 2 Oicend .05\% 8ulf

No. 6 Fuel

Carton alack fond

Apohall

Lubes 1 Waxen

Marketable Coke, FOE

Potrochem Nephthe

Peuroctiam ous on

BTX

Propane

Propyiene

Procens Gas salo

Pranl Pud Burned

Loss (OUn)

Tonal

ApyeMrierlaly

Crude

Notural Baedine

Roformese (100 RON)

Vacuum Gas Oll

N-Butane

100-Butane

MTRE

Mothanol

Propane

Nal. Ges to fle Pent, FOE

Tolut

Net Inouse (A) Mn. Lags Iod

Yilinles

NaL. Gea Purchased, FOE

Eloc. MMKKWH'D

Mant Fuel Burned

Toal Utillithe Uesed

\begin{tabular}{|c|c|c|c|c|}
\hline \multicolumn{3}{|c|}{ MAPCO } & - BFOE & - MAPCO \\
\hline asw & $66 \%$ & $\Delta$ & & \\
\hline $8,658.5$ & $\begin{array}{r}857.1 \\
84.4 \\
08.7 \\
836.0 \\
1.61 .2\end{array}$ & $\begin{array}{r}0.001 .4) \\
02.4 \\
81.7 \\
850.0 \\
22.7\end{array}$ & $\begin{array}{l}0.745 \\
0.729 \\
0.728 \\
0.720\end{array}$ & $\begin{array}{r}(746.3) \\
72.6 \\
64.4 \\
600.4 \\
\end{array}$ \\
\hline
\end{tabular}

$3.0 \quad 0.0$

$213.0 \quad 293.0$

$134.0 \quad 134.0$

848.0 s4to

$15.4 \quad 18.4$

$4.0 \quad 4.0$

$103.0 \quad 103.0$

$24.0 \quad 24.0$

4.656 .9

$18.0 \quad 18.0$

$18.0 \quad 18.0$

$16.0 \quad 16.0$

$79.1 \quad 74.8$

22.0

1.0

1.0

197.3

(108.3)

176.0

(102.4)

$3,000.7$

$(7.7) \quad 1.00$

(7.7)

(4.0) $\quad 0.60$

(2.3)

$3,013.2$

$2,707,1$

$\mathbf{8 8 . 0}$

35.0

27.0

$1+3.1$

29.2

24.0

1.2

$\begin{array}{r}2.0 \\ 4.5 \\ \hline 3.013 .2\end{array}$

$$
\begin{array}{r}
2,600.4 \\
38.0 \\
25.0 \\
27.0 \\
147.6 \\
23.5 \\
196.6 \\
0.2 \\
2.0 \\
4.6 \\
\hline 3.008 .5
\end{array}
$$

$4.8 \quad 0.88$

0.65

0.22

3.1

(b.)

22.6

(6.5)

(33.1)

\begin{tabular}{rrrrr}
37.9 & 47.1 & 9.2 & 1.00 & 9.2 \\
21.9 & 21.2 & $(0.7)$ & 1.60 & $(1.1)$ \\
197.3 & 176.9 & $\frac{(20.4)}{(11.8)}$ & 1.00 & $(20.4)$ \\
\hline 257.3 & $\frac{125.2}{(12.5)}$ & & &
\end{tabular}

Lost Fnurox

Tota Nes Inputs plus Utithies

(14.5)

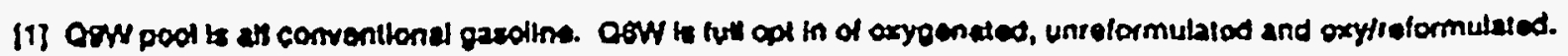
(2) Compration fectors indicated for varlable products. 
TABLE D.2 PADD III Phase II Winter Gasoline Blendstocks (percent)

RFG NO $\mathrm{NO}_{\mathrm{x}}$ reduction minimum $=0 \%$

RFG TAP reduction minimum $=19.5 \%$

RFG production share $=62 \%$

\begin{tabular}{|c|c|c|c|c|c|}
\hline & \multicolumn{2}{|c|}{$\begin{array}{c}\text { RFG oxygenated with } \\
\text { ether }\end{array}$} & \multicolumn{3}{|c|}{$30 \%$ of RFG oxygennted with ethanol } \\
\hline & RFG & CG & $\begin{array}{l}\text { RFG with } \\
\text { ethanol }\end{array}$ & $\begin{array}{l}\text { RFG with } \\
\text { ether }\end{array}$ & CG \\
\hline Butane & 8.8 & 7.3 & 7.4 & 8.9 & 7.7 \\
\hline Reformare & 18.4 & 32.4 & 13.1 & 16.1 & 392 \\
\hline Straight ron saphtha & 2.5 & & 6.3 & & 0.2 \\
\hline $\mathrm{CS}+$ isomerate & & 16.3 & 1.5 & & 15.8 \\
\hline FCC napintha & 35.6 & 21.0 & 36.7 & 43.5 & 12.0 \\
\hline Coker napintha & & 2.7 & & & 2.6 \\
\hline Fiydrocrackate & 3.3 & 3.9 & & 4.8 & 3.9 \\
\hline Allylate & 8.8 & 13.4 & 17.8 & 5.5 & 15.9 \\
\hline Polymer gasolines & & & & & 2.8 \\
\hline \multicolumn{6}{|l|}{ Dimate } \\
\hline WITEE & 12.3 & & & 12.6 & \\
\hline TAME & 0.4 & & & & \\
\hline Ethanol & & & 6.6 & & \\
\hline Tohuene/xplene & 0.4 & & & 0.5 & \\
\hline Natural gasoline & 5.5 & & 8.5 & 4.0 & \\
\hline \multicolumn{6}{|l|}{ Priolysis gasolite } \\
\hline Raffinouters & 3.8 & & 2.1 & 4.1 & \\
\hline Other & & 0.2 & & & \\
\hline
\end{tabular}


TABLE D.3 PADD III Phase II Raw Material Inputs $\left(10^{3} \mathrm{bbl} / \mathrm{d}\right.$ or MBD)

\begin{tabular}{|c|c|c|c|}
\hline & $\begin{array}{l}\text { RFG oxygensted } \\
\text { with ether }\end{array}$ & $\begin{array}{c}\text { 30\% of RFG } \\
\text { oxygenated with } \\
\text { ethanol }\end{array}$ & $\begin{array}{l}\text { Ethanol effect: } \\
\text { Column } 3 \text { mimus } \\
\text { Cohumn } 2\end{array}$ \\
\hline $\begin{array}{l}\text { Crude oil } \\
\text { (1.49 wt \% sulfur; } 32.3^{\circ} \text { APD) }\end{array}$ & 5630.7 & 5615.2 & -15.5 \\
\hline Namral gas (FOE) & 164.0 & 164.0 & 0 \\
\hline Namaral gasoline & 113.3 & 113.3 & 0 \\
\hline Ethane & 4.1 & 4.1 & 0 \\
\hline Isobutane & 78.2 & 78.2 & 0 \\
\hline Normal butane & 207.3 & 244.3 & +37.0 \\
\hline Naphthas & 57.1 & 57.1 & 0 \\
\hline Gas oils & 172.8 & 172.8 & 0 \\
\hline MTBE & 196.1 & 125.4 & -70.7 \\
\hline Methanol & 16.2 & 15.3 & -0.9 \\
\hline Ethanol & & 38.4 & +38.4 \\
\hline Total raw material inguts & 6639.8 & 6628.0 & -11.8 \\
\hline
\end{tabular}


TABLE D.4 PADD III Phase II Outputs $\left(10^{3} \mathrm{bbl} / \mathrm{d}\right.$ or MBD)

\begin{tabular}{|c|c|c|c|}
\hline & $\begin{array}{l}\text { RFG arggenated } \\
\text { with ether }\end{array}$ & $\begin{array}{l}30 \% \text { of RFG } \\
\text { axygeanted with } \\
\text { ethrool }\end{array}$ & $\begin{array}{l}\text { Ethanol effect: } \\
\text { Cohmon } 3 \text { mims } \\
\text { Cohuman } 2\end{array}$ \\
\hline RFG oxygennted with ethanol & 0 & 577.8 & +577.8 \\
\hline RFG oxygenrted with ethers & 1926.7 & 1348.7 & -578.0 \\
\hline CG & 1165.9 & 1165.9 & 0 \\
\hline Propane & 26.9 & 0 & -26.9 \\
\hline Plant fucl burned & 494.7 & 501.9 & +7.2 \\
\hline 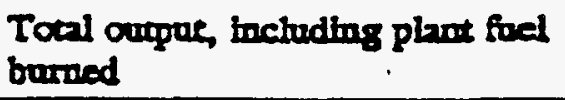 & 6752.3 & 6729.9 & -22.4 \\
\hline $\begin{array}{l}\text { Tocai saleabie autput (excindes } \\
\text { plant fuel burned) }\end{array}$ & 6257.6 & 6228.0 & -29.6 \\
\hline
\end{tabular}


APPENDIX E:

COST OF PRODUCTION ESTIMATE FOR MTBE 
PROCESS: PLOMTBEI PRICES : MTAEIS9S
COST OF PROOUCTION ESTIMATE fOR : PROCESS :

from field Butanes

Capital costs

Bateery Liaits offsizes

Total Fixed Imv. working capieal

Cparaeting Rate: Throughpur:

Proouction cost simury

$$
\begin{aligned}
& \text { PRICE. } \\
& \text { UNITS Dollars } \\
& \text { PER IT NWNIT }
\end{aligned}
$$

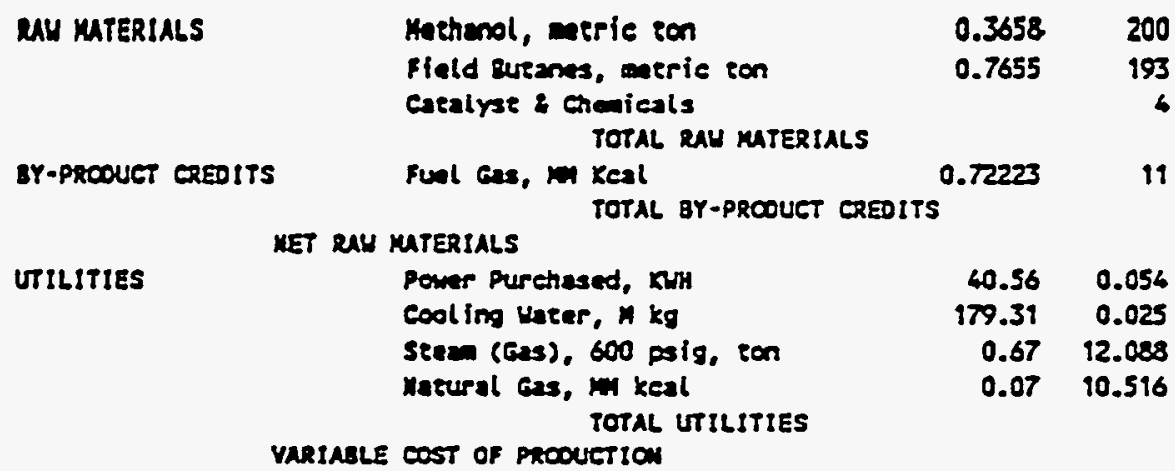

DIRECT CLSH COSTS

allocated cash costs

35.83 Thousand 0ollars 60.63 mossand Dollars 49.07 Thoweand Dollars $6.00 \times$ of 1586

65 I Labor Sepervision oirect overthend TOTAL OIRECT CASH COSTS

General Plane Overtiend insurance, Proparty Tax total allocated cash costs FUL CASH cost of PRoOUction

65 I Labor Maineenance $1.5 \approx$ Total fixed imvestwent

MONOCASH ALLOCATIOAS Deprecistion

VET COST Of Propuction

10 Years for OSBL 10 Years for $158 \mathrm{~L}$

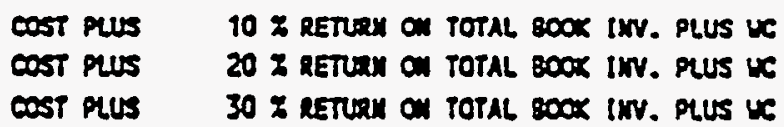

\begin{tabular}{rrr} 
& Mlllion Dollars \\
0.16 & BOCK & REPl \\
226.9 & 226.9 & 226.9 \\
90.7 & 90.7 & 90.7 \\
\hline 317.6 & 317.6 & 317.6 \\
& & 27.0
\end{tabular}

Ninut

Dollars cost in Dollars PER iT Dollars Por Gal

$\begin{array}{rrr}73.2 & 36.58 & \\ 167.9 & 73.96 & \\ 6.1 & 2.03 & \\ 225.1 & 112.56 & 0.633 \\ (7.6) & (3.80) & \\ (7.6) & (3.80) & (0.021) \\ 217.5 & 108.76 & 0.612 \\ 2.2 & 1.10 & \\ 6.5 & 2.23 & \\ 8.1 & 4.05 & \\ 0.8 & 0.38 & \\ 15.5 & 7.76 & 0.046 \\ 233.0 & 116.52 & 0.655 \\ & & \\ 2.3 & 1.15 & \\ 1.1 & 0.57 & \\ 0.3 & 0.15 & \\ 18.1 & 9.07 & \\ 1.7 & 0.86 & \\ 23.6 & 11.78 & 0.066 \\ 16.2 & 7.11 & \\ 9.5 & 6.76 & \\ 23.7 & 11.87 & 0.067 \\ 280.3 & 160.17 & 0.768 \\ & & \\ 18.1 & 9.07 & \\ 45.6 & 22.69 & \\ 343.9 & 171.93 & 0.967 \\ & & \\ 612.8 & 206.39 & 1.161 \\ 481.7 & 260.85 & 1.355 \\ 550.6 & 273.31 & 1.569\end{array}$

Source: Chem Systems, Inc. (Table A4.40, 1992). 
APPENDIX F:

ETHANOL WEIGHTING FOR PROGRAMWIDE ANALYSIS 


\begin{tabular}{lc}
\hline \multicolumn{1}{c}{ Item } & $\begin{array}{c}\text { Millions of } \\
\text { Gallons per } \\
\text { Period }\end{array}$ \\
\hline 1995 expected winter ethanol production capacity & 741 \\
EPA winter EtOH capacity expansion by 1996 & 253 \\
Total 1996 winter ethanol capacity & 994 \\
Current winter ethanol use & 641 \\
Current excess winter ethanol (= current capacity - current use) & 100 \\
Total RFG EtOH demand & 601 \\
Total "new" EtOH available & 353 \\
Total "existing" EtOH diverted to RFG & 248 \\
& \\
Fraction existing & $41.2 \%$ \\
\hline
\end{tabular}


APPENDIX G:

DELUCCH'S BASE-CASE ESTMMATES OF GREENHOUSE GAS EMISSIONS OF ALTERNATIVE FUELS AND SUMMARY REPORTS ESTIMATING ENERGY TO PRODUCE ETHANOL 
TABLE G.1 Results: Fuel Cycle $\mathrm{CO}_{2}$-Equivalent Emissions (excluding CFCs), by Fuel and Stage

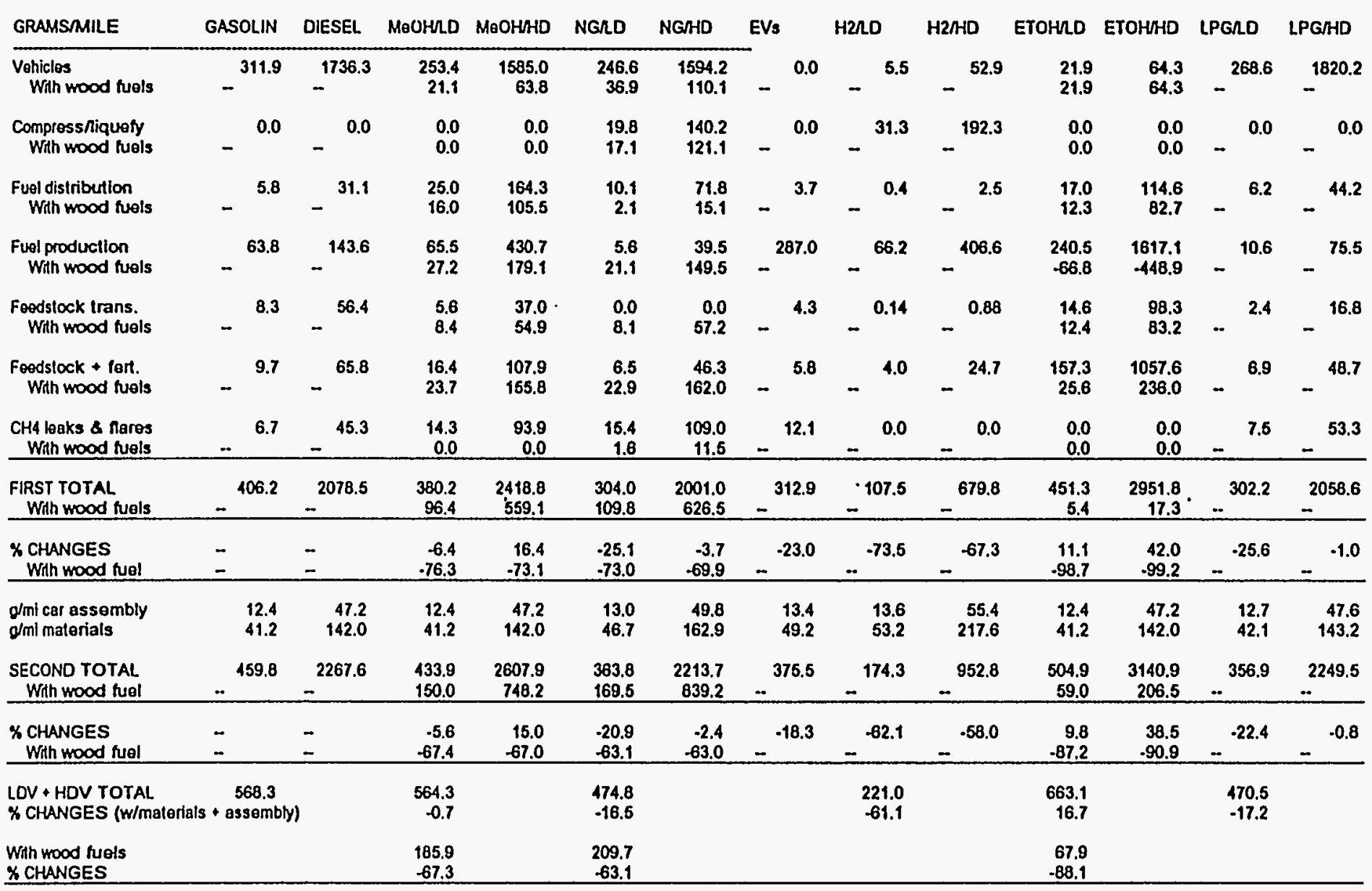


TABLE G.2 Estimates of Energy Used to Grow Corn and Produce Ethanol (Btu Process Energy/Btu Ethanol)

\begin{tabular}{|c|c|c|c|c|c|c|c|c|}
\hline \multirow[b]{2}{*}{ Reference } & \multirow[b]{2}{*}{ Fertllizer ${ }^{a}$} & \multirow[b]{2}{*}{ Farming } & \multirow[b]{2}{*}{$\begin{array}{c}\text { Farm } \\
\text { Equipment }\end{array}$} & \multirow[b]{2}{*}{$\begin{array}{l}\text { Corn } \\
\text { Transport }\end{array}$} & \multicolumn{4}{|c|}{ Conversion to Ethanol } \\
\hline & & & & & Coal & Electricity ${ }^{b}$ & Facility & Notes \\
\hline Glampietro and Pimentel (1990) & 0.33 & 0.16 & 0.13 & 0.06 & 0.90 & 1? & 0.06 & c \\
\hline Jones (1989) & NE & NE & NE & NE & 0.79 & 0.057 & NE & $d$ \\
\hline Jones (1989) & NE & NE & NE & $\mathrm{NE}$ & 0.60 & 0.071 & NE & e \\
\hline Anderson (1988) & \multicolumn{2}{|c|}{$\cdots \cdots-0.41-0.62 \cdots \cdots$} & NE & $?$ & $0.57-0.85$ & $?$ & NE & 1 \\
\hline Ferchak and Pye (1981) & \multirow{2}{*}{\multicolumn{2}{|c|}{$\cdots$}} & $1 ?$ & NE & \multicolumn{2}{|c|}{--see Katzen (1979)-.. } & & $g$ \\
\hline Katzen Associates (1979) & & & NE & 1 & 0.49 & 0.050 & $<0.01$ & $\mathrm{~h}$ \\
\hline Chambers el al. (1979) & 0.41 & 0.34 & 0.09 & 0.11 & 0.59 & $1 ?$ & 0.04 & $i$ \\
\hline Ho (1989) & 0.21 & 0.22 & NE & NE & 0.59 & 0.052 & NE & $j$ \\
\hline Parisi (1983) & 0.28 & 0.23 & 0.10 & 0.05 & 0.42 & 1 & 0.09 & $\mathrm{k}$ \\
\hline Marland and Turhollow (1990) & 0.17 & 0.10 & NE & NE & $0.33-0.53$ & 0.048 & NE & 1 \\
\hline Pimentel $(1990)$ & $0.27(0.33)$ & 0.27 & 0.07 & 0.006 & NE & NE & NE & $m$ \\
\hline Wayman and Parekh (1990) & NE & NE & NE & NE & $0.28-0.77$ & $0.036-0.049$ & NE & $n$ \\
\hline Energy Fuels Development (1990) & $\ldots \ldots-0.2$ & .......... & NE & NE & 0.38 & 0.11 & NE & 0 \\
\hline Keim, IRI (1989) & NE & NE & NE & NE & 0.63 & 0.052 & NE & $p$ \\
\hline This report & 0.19 & 0.10 & NE & 0.03 & $0.35-0.60$ & 0.050 & NE & $q$ \\
\hline
\end{tabular}

An "I" under "conversion to ethanol/electricity" means electricity use is included in the estimate of coal-energy requirement; "?" means it is not clear if the electricity-energy is included in the coal-energy or if it has simply not been counted. - " $"$ " under "corn transport" means that it is not clear if corn transport energy has been included under farming energy or not. "I" under "corn transport" or "farm equipment" means that the energy is included under "farming" and "fertilizer." "NE" means that the particular kind of energy use is not estimated.

Estimates are based on higher heating values, unless stated otherwise.

For methanol, I assume $22.7 \mathrm{~kJ} / \mathrm{g}$ or $64,500 \mathrm{Btu} / \mathrm{gal} \mathrm{HHV}$ and $19.95 \mathrm{~kJ} / \mathrm{g}$ or $56,700 \mathrm{Btu} / \mathrm{gal} \mathrm{LHV;} \mathrm{for} \mathrm{ethanol,} \mathrm{I} \mathrm{assume} 84,600 \mathrm{Blu} / \mathrm{gal} \mathrm{HHV}$ and $75,670 \mathrm{Btu} / \mathrm{gal} \mathrm{LHV}$.

a Does not include $\mathrm{N}_{2} \mathrm{O}$ emissions from denitrification of fertilizer (see Appendix $\mathrm{N}$ ).

blectricity counted at 3,412 Btu/kWh, unless otherwise noted. 


\section{TABLE G.2 (Cont.)}

M. Giampietro and D. Pimental, "Alcohol and Biogas Production from Biomass," Critical Reviews in Plant Sciences 9:213-233 (1990).

K.W. Jones, "Operational Case Histories of the South Point Ethanol and Kentucky Agricultural Energy Corporation Fuel Ethanol Plants," in Energy from Biomass and Wastes XII, 1343-1375, edited by D.L. Klass, Institute of Gas Technology, Chicago, Ill. (1989).

R.C. Anderson et al., The Economics of Gasoline Ethanol Blends, Research Study \#045, American Petroleum Institute, Washington, D.C., Nov. (1988).

J.D. Ferchak and E.K. Pye, "Utilization of Biomass in the U.S. for the Production of Ethanol Fuel as a Gasoline Replacement -- I, Terrestrial Resource Potential," Solar Energy 26:9-16 (1981).

J.D. Ferchak and E.K. Pye, "Utilization of Biomass in the U.S. for the Production of Ethanol Fuel as a Gasoline Replacement -- II, Energy Requirements with Emphasis on Lignocellulosic Conversion," Solar Energy 26:17-25 (1981).

Raphael Katzen Associates, Grain Motor Fuel Alcohol Technical and Economic Assessment, HCP/J7739-01, for the U.S. Department of Energy, June (1979).

R.S. Chambers et al., "Gasohol: Does It or Doesn't It Produce Negative Net Energy?" Science 206:789-795 (1979).

S.P. Ho (Amoco Oil Company), "Global Warming Impact of Ethanol Versus Gasoline," presented at Clean Air Issues and America's Motor Fuel Business, Washington, D.C., Oct. 3-5 (1989).

F. Parisi, "Energy Balances or Ethanol as a Fuel," Advances in Biochemical Engineering/Biotechnology 28:42-68 (1983).

G. Marland and A. Turhollow, $\mathrm{CO}_{2}$ Emissions from Production and Combustion of Fuel Ethanol Made from Corn, ORNLTM-1180, Oak Ridge National Laboratory, Oak Ridge, Tennessee, May (1990).

D. Pimentel, Ethanol Fuels: Energy Security and the Environment, College of Agriculture and Life Sciences, Cornell University, Ithaca, New York, Sept. 18 (1990).

M. Wayman and S.R. Parekh, Biotechnology of Biomass Conversion, Fuels and Chemicals from Renewable Resources, Open University Press, Milton Keynes, London (1990).

Energy Fuels Development Corporation, "Moving Beyond the Myths," Oct. (1989).

C.R. Keim, in "U.S. Gasoline Outlook, 1989-1994," Information Resources, Inc., Transmitted by S.P. Ho, Amoco Oil Company, Naperville, Illinois (1989). 


\section{APPENDIX H:}

ENERGY AND GREENHOUSE GAS RESULTS FOR REFORMULATED GASOLINES ON THE BASIS OF THE USDA'S AND HO'S ESTIMATES OF ENERGY REQUIRED TO PRODUCE ETHANOL 
, 
TABLE H.1 Fuel Volume and Energy Content for RFG with 2.1 wt\% Oxygen: USDA Estimates (Energy, Oil, and $\mathrm{CO}_{2}$-Equivalent Emissions for RFG Volumes That Contain the Same Energy as Summer RFG with MTBE at 2.1 wt\% Oxygen)

\begin{tabular}{|c|c|c|c|c|c|c|c|c|c|c|c|c|}
\hline FUEL TYPE & $\begin{array}{l}\text { COMPO- } \\
\text { NENTS }\end{array}$ & $\begin{array}{l}\text { INTIAL } \\
\text { VOLUME }\end{array}$ & $\begin{array}{l}\text { ENERGY } \\
\text { CONTENT } \\
\text { OF INITIAL } \\
\text { VOLUME } \\
\end{array}$ & $\begin{array}{l}\text { REVISED VOL TO } \\
\text { DELIVER EOUAL } \\
\text { BTU AS SUMMER } \\
\text { RFG AT } 2.1 \% \text { OXY } \\
\text { WIMTBE ONLY }\end{array}$ & $\begin{array}{l}\text { AEVISED } \\
\text { ENERGY } \\
\text { CONTENT } \\
\end{array}$ & $\begin{array}{c}\text { OIL } \\
\text { CONTENT } \\
\text { (FEEDSTOCK) }\end{array}$ & $\begin{array}{c}\text { ENERGY } \\
\text { RECUIRED } \\
\text { TO PRODUCE } \\
\text { AFG } \\
\end{array}$ & $\begin{array}{c}\text { OlL } \\
\text { AEQUIRED } \\
\text { TOPRODUCE } \\
\text { RFG } \\
\end{array}$ & $\begin{array}{l}\text { TOTAL. ENERGY } \\
\text { REQUIRED TO } \\
\text { DELIVER RFG } \\
\end{array}$ & $\begin{array}{c}\text { TOTAL } \\
\text { FOSSIL ENERGY } \\
\text { REQUIRED TO } \\
\text { DELIVER RFG }\end{array}$ & $\begin{array}{c}\text { TOTAL OIL } \\
\text { REQUIRED TO } \\
\text { DELIVER RFG } \\
\end{array}$ & $\begin{array}{l}\text { CO2. } \\
\text { EQUIVALENT } \\
\text { EMISSIONS } \\
\end{array}$ \\
\hline & & GALLONS & BTU & GALLONS & BTU & BTU & BTU & BTU & BIU & BTU & BTu & $\mathbf{G}$ \\
\hline \multicolumn{13}{|c|}{$\begin{array}{l}\text { SUMMER FUELLS ANALYSIS } \\
\text { RFG }\end{array}$} \\
\hline $\begin{array}{l}\text { WITH MTBE } \\
\text { AT 2.1\% O2 }\end{array}$ & $\begin{array}{l}\text { HCs } \\
\text { MTEE } \\
\text { TOTAL }\end{array}$ & $\begin{array}{l}0.885 \\
0.116 \\
1.000\end{array}$ & $\begin{array}{r}101,275 \\
10,799 \\
112,075\end{array}$ & $\begin{array}{l}0.885 \\
0.116 \\
1.000\end{array}$ & $\begin{array}{r}101,275 \\
10,799 \\
112,075\end{array}$ & $\begin{array}{r}101,275 \\
641 \\
101,916\end{array}$ & $\begin{array}{r}16,017 \\
3,216 \\
19,233\end{array}$ & $\begin{array}{r}9,072 \\
0 \\
9,072\end{array}$ & $\begin{array}{r}117,293 \\
114,015 \\
131,308\end{array}$ & $\begin{array}{r}117.293 \\
14.015 \\
131,308\end{array}$ & $\begin{array}{r}110,347 \\
641 \\
110,988\end{array}$ & $\begin{array}{r}10.749 \\
1,094 \\
11,044\end{array}$ \\
\hline $\begin{array}{l}\text { RFG } \\
\text { WITH ETBE } \\
\text { AT } 2.1 \% \text { O2 } \\
\text { (NEWETOH) } \\
\text { RFG }\end{array}$ & $\begin{array}{l}\text { HCs } \\
\text { ETBE } \\
\text { TOTAL }\end{array}$ & $\begin{array}{l}0.866 \\
0.134 \\
1.000\end{array}$ & $\begin{array}{r}89,157 \\
12,985 \\
112,142\end{array}$ & $\begin{array}{l}0.865 \\
0.134 \\
0.899\end{array}$ & $\begin{array}{r}99,098 \\
12,977 \\
112,075\end{array}$ & $\begin{array}{r}89,098 \\
671 \\
89,768\end{array}$ & $\begin{array}{r}10,200 \\
15,457 \\
5,213 \\
20,670\end{array}$ & $\begin{array}{r}0,012 \\
8,661 \\
183 \\
8,844\end{array}$ & $\begin{array}{r}114,554 \\
18,180 \\
132,744\end{array}$ & $\begin{array}{r}114.554 \\
13.515 \\
128,069\end{array}$ & $\begin{array}{r}107,758 \\
854 \\
108,612\end{array}$ & $\begin{array}{r}11,014 \\
10,479 \\
1.310 \\
11.789\end{array}$ \\
\hline $\begin{array}{l}\text { WTH ETBE } \\
\text { AT 2.1\% O2 } \\
\text { (EXISTING ETOH) }\end{array}$ & $\begin{array}{l}\text { HCs } \\
\text { ETBE } \\
\text { - ETOH } \\
\text { CG } \\
\text { TOTAL }\end{array}$ & $\begin{array}{l}0.866 \\
0.134 \\
0.060 \\
0.041 \\
0.981\end{array}$ & $\begin{array}{r}89,157 \\
12,885 \\
4,678 \\
4,678 \\
112,142\end{array}$ & $\begin{array}{l}0.865 \\
0.134 \\
0.060 \\
0.041 \\
0.880\end{array}$ & $\begin{array}{r}99,098 \\
12,977 \\
4,675 \\
4,675 \\
112,075\end{array}$ & $\begin{array}{r}89,098 \\
671 \\
234 \\
4.675 \\
104,210\end{array}$ & $\begin{array}{r}15,457 \\
5,213 \\
3,128 \\
724 \\
18,266\end{array}$ & $\begin{array}{r}8,661 \\
183 \\
192 \\
550 \\
9,202\end{array}$ & $\begin{array}{r}114,554 \\
18,180 \\
7,803 \\
5,399 \\
130,340\end{array}$ & $\begin{array}{r}114,554 \\
13.515 \\
3.128 \\
5.399 \\
130,340\end{array}$ & $\begin{array}{r}107.758 \\
854 \\
425 \\
5,225 \\
113,412 \\
113.4\end{array}$ & $\begin{array}{r}10,479 \\
1,310 \\
510 \\
483 \\
11.773\end{array}$ \\
\hline CG IN PADD \| & $\begin{array}{l}\text { HCs } \\
\text { MTBE } \\
\text { TOTAL }\end{array}$ & $\begin{array}{l}0.980 \\
0.020 \\
1.000\end{array}$ & $\begin{array}{r}112,210 \\
1,870 \\
114,080\end{array}$ & $\begin{array}{l}0.963 \\
0.020 \\
0.882\end{array}$ & $\begin{array}{r}110,237 \\
1,837 \\
112,075\end{array}$ & $\begin{array}{r}110,237 \\
1,032 \\
111,269\end{array}$ & $\begin{array}{r}17,069 \\
467 \\
17,537\end{array}$ & $\begin{array}{r}12,860 \\
0 \\
12,060\end{array}$ & $\begin{array}{r}127,306 \\
2,305 \\
129,611\end{array}$ & $\begin{array}{r}127,306 \\
2,305 \\
129,611\end{array}$ & $\begin{array}{r}123,197 \\
1,032 \\
124,229\end{array}$ & $\begin{array}{r}11,634 \\
186 \\
11,821\end{array}$ \\
\hline \multicolumn{13}{|c|}{$\begin{array}{l}\text { WINTER FUELS ANALYSIS } \\
\text { RFG }\end{array}$} \\
\hline $\begin{array}{l}\text { WITH MTBE } \\
\text { AT } 2.1 \% 02 \\
\text { RFG }\end{array}$ & $\begin{array}{l}\text { HCs } \\
\text { MTBE } \\
\text { TOTAL }\end{array}$ & $\begin{array}{l}0.885 \\
0.116 \\
1.000\end{array}$ & $\begin{array}{r}99,683 \\
10,799 \\
110,482\end{array}$ & $\begin{array}{l}0.897 \\
0.117 \\
1.014\end{array}$ & $\begin{array}{r}101,120 \\
10,855 \\
112,075\end{array}$ & $\begin{array}{r}101,120 \\
0 \\
101,120\end{array}$ & $\begin{array}{r}13,481 \\
3,318 \\
16,789\end{array}$ & $\begin{array}{r}7,884 \\
0 \\
7,884\end{array}$ & $\begin{array}{r}114,601 \\
14,273 \\
128,874\end{array}$ & $\begin{array}{r}114,601 \\
14,273 \\
128,874\end{array}$ & $\begin{array}{r}109,104 \\
0 \\
109,104^{\circ}\end{array}$ & $\begin{array}{r}10.279 \\
1.110 \\
11,389\end{array}$ \\
\hline $\begin{array}{l}\text { WTH ETHANOL } \\
\text { AT 2.1\% O2 } \\
\text { (NEWETOH) } \\
\text { RFG }\end{array}$ & $\begin{array}{l}\text { HCs } \\
\text { ETOH } \\
\text { TOTAL }\end{array}$ & $\begin{array}{l}0.940 \\
0.060 \\
1.000\end{array}$ & $\begin{array}{r}105,938 \\
4,678 \\
110,616\end{array}$ & $\begin{array}{l}0.852 \\
0.061 \\
1.013\end{array}$ & $\begin{array}{r}107,335 \\
4,740 \\
112,075\end{array}$ & $\begin{array}{r}107,335 \\
237 \\
107.572\end{array}$ & $\begin{array}{r}14,435 \\
3,171 \\
17,606\end{array}$ & $\begin{array}{r}8,656 \\
194 \\
8,851\end{array}$ & $\begin{array}{r}121,769 \\
7,011 \\
129,680\end{array}$ & $\begin{array}{r}121,769 \\
3.171 \\
124.940\end{array}$ & $\begin{array}{r}115,981 \\
431 \\
116,422\end{array}$ & $\begin{array}{r}10,933 \\
517 \\
11,450\end{array}$ \\
\hline $\begin{array}{l}\text { WTHHETHANOL } \\
\text { AT } 2.1 \% \text { O2 } \\
\text { (EXISTING ETOH) }\end{array}$ & $\begin{array}{l}\text { HCs } \\
\text { ETOH } \\
\text { CG } \\
\text { TOTAL }\end{array}$ & $\begin{array}{r}0.940 \\
0 \\
0.042 \\
0.982\end{array}$ & $\begin{array}{r}105,938 \\
0 \\
4,678 \\
10,616\end{array}$ & $\begin{array}{l}0.952 \\
0.000 \\
0.042 \\
0.904\end{array}$ & $\begin{array}{r}107,335 \\
0 \\
4,740 \\
112,075\end{array}$ & $\begin{array}{r}107,335 \\
0 \\
44.740 \\
112,075\end{array}$ & $\begin{array}{r}14,435 \\
0 \\
668 \\
15,103\end{array}$ & $\begin{array}{r}8,656 \\
0 \\
487 \\
0,144\end{array}$ & $\begin{array}{r}121,769 \\
0 \\
5,408 \\
127,178\end{array}$ & $\begin{array}{r}121,769 \\
0 \\
5,408 \\
127,178\end{array}$ & $\begin{array}{r}115,891 \\
0 \\
5,227 \\
121,218\end{array}$ & $\begin{array}{r}10,833 \\
0 \\
488 \\
11,422\end{array}$ \\
\hline & $\begin{array}{l}\text { HCs } \\
\text { MTBE } \\
\text { TOTAL }\end{array}$ & $\begin{array}{l}0.880 \\
0.020 \\
1.000\end{array}$ & $\begin{array}{r}110,446 \\
1,870 \\
112,316\end{array}$ & $\begin{array}{l}0.978 \\
0.020 \\
0.998\end{array}$ & $\begin{array}{r}110,209 \\
1,866 \\
112,075\end{array}$ & $\begin{array}{r}110,209 \\
413 \\
110,622\end{array}$ & $\begin{array}{r}15,537 \\
530 \\
16,067\end{array}$ & $\begin{array}{r}11,330 \\
0 \\
11.330\end{array}$ & $\begin{array}{r}125,746 \\
2,396 \\
128,141\end{array}$ & $\begin{array}{r}125,746 \\
2,396 \\
128,141\end{array}$ & $\begin{array}{r}121,538 \\
413 \\
121,952\end{array}$ & $\begin{array}{r}11,356 \\
189 \\
11,545\end{array}$ \\
\hline
\end{tabular}

NEW ETOH : INCREMENTALLY PRODUCED ETHANOL AS OPPOSED TOETHANOL DIVERTED FROM EXISTING MARKETS

EXISTING ETOH = ETHANOL DIVERTED FROM EXISTING MARKETS 
TABLE H.2 Fuel Volume and Energy Content for RFG with 2.7 wt\% Oxygen: USDA Estimates

(Energy, Oil, and $\mathrm{CO}_{2}$-Equivalent Emissions for RFG Volumes That Contain the Same Energy as Summer RFG with MTBE at $2.1 \mathrm{wt} \%$ Oxygen)

\begin{tabular}{|c|c|c|c|c|c|c|c|c|c|c|c|c|}
\hline FUEL TYPE & $\begin{array}{l}\text { COMPO- } \\
\text { NENTS } \\
\end{array}$ & $\begin{array}{l}\text { INTIAL } \\
\text { VOLUME } \\
\text { GALIONS }\end{array}$ & $\begin{array}{r}\text { ENERGY } \\
\text { CONTENT } \\
\text { OF INITIAL } \\
\text { VOLUME } \\
\text { BTU }\end{array}$ & $\begin{array}{l}\text { REVISED VOL TO } \\
\text { DELIVER EQUAL } \\
\text { BTU AS SUMMER } \\
\text { RFG AT } 2.1 \% \text { OXY } \\
\text { WIMTBE ONLY } \\
\end{array}$ & $\begin{array}{l}\text { REVISEO } \\
\text { ENERGY } \\
\text { CONTENT } \\
\text { COTI! }\end{array}$ & $\begin{array}{r}\text { OIL. } \\
\text { CONTENT } \\
\text { FEEDSTOCK) }\end{array}$ & $\begin{array}{r}\text { ENERGY } \\
\text { REQUIRED } \\
\text { TO PRODUCE } \\
\text { RFG } \\
\text { RTIU }\end{array}$ & $\begin{array}{r}\text { OlL } \\
\text { REQUIRED } \\
\text { TO PROOUCE } \\
\text { AFG } \\
\text { RTII }\end{array}$ & $\begin{array}{c}\text { TOTAL ENERGY } \\
\text { REQUIRED TO } \\
\text { DELIVER RFG } \\
\end{array}$ & $\begin{array}{r}\text { TOTAL } \\
\text { FOSSIL. ENERGY } \\
\text { REQUIRED TO } \\
\text { DELIVER RFG } \\
\end{array}$ & $\begin{array}{r}\text { TOTAL OLL } \\
\text { REQUIRED TO } \\
\text { DELIVER RFG } \\
\text { PRII }\end{array}$ & $\begin{array}{r}\mathrm{CO2} \\
\text { EQUIVALENT } \\
\text { EMISSLONS }\end{array}$ \\
\hline \multirow[b]{2}{*}{$\begin{array}{l}\text { FFG } \\
\text { WITH MTBE } \\
\text { AT } 2.7 \% \text { O2 }\end{array}$} & & GALLONS & BTU & GALLONS & BTU & BTU & BTU & BTU & BTU & BTU & Bत̃u & \\
\hline & $\begin{array}{l}\text { HCs } \\
\text { MTBE } \\
\text { TOTAL. }\end{array}$ & $\begin{array}{l}0.852 \\
0.149 \\
1.000\end{array}$ & $\begin{array}{r}95,964 \\
13,885 \\
109,849\end{array}$ & $\begin{array}{l}0.869 \\
0.152 \\
1.020\end{array}$ & $\begin{array}{r}97,908 \\
14,166 \\
112,075\end{array}$ & $\begin{array}{r}97,908 \\
0 \\
97,908\end{array}$ & $\begin{array}{r}13,053 \\
4,291 \\
17,344\end{array}$ & $\begin{array}{r}7.730 \\
0 \\
7.730\end{array}$ & $\begin{array}{r}110,961 \\
18,457 \\
129,418\end{array}$ & $\begin{array}{r}110.961 \\
18,457 \\
129.418\end{array}$ & $\begin{array}{r}105,639 \\
0 \\
105,639\end{array}$ & $\begin{array}{r}9,953 \\
1.435 \\
11,388\end{array}$ \\
\hline $\begin{array}{l}\text { RFG } \\
\text { WTHH ETHANOL } \\
\text { AT } 2.7 \% \text { O2 } \\
\text { (NEWETOH) } \\
\text { RFG }\end{array}$ & $\begin{array}{l}\text { HCs } \\
\text { ETOH } \\
\text { TOTAL }\end{array}$ & $\begin{array}{l}0.823 \\
0.077 \\
1.000\end{array}$ & $\begin{array}{r}104,045 \\
5,988 \\
110,033\end{array}$ & $\begin{array}{l}0.940 \\
0.078 \\
1.019\end{array}$ & $\begin{array}{r}105,975 \\
6,099 \\
112,075\end{array}$ & $\begin{array}{r}105,975 \\
305 \\
106,280\end{array}$ & $\begin{array}{r}14,252 \\
4,080 \\
18,332\end{array}$ & $\begin{array}{r}8,547 \\
250 \\
8,797\end{array}$ & $\begin{array}{r}120,227 \\
10.180 \\
130,407\end{array}$ & $\begin{array}{r}120.227 \\
4.080 \\
124.308\end{array}$ & $\begin{array}{r}114,522 \\
555 \\
115,077\end{array}$ & $\begin{array}{r}10.795 \\
665 \\
11.460\end{array}$ \\
\hline $\begin{array}{l}\text { WTHH ETHANOL } \\
\text { AT } 2.7 \% \text { O2 } \\
\text { (EXISTING ETOH) } \\
\text { CG INPADD II }\end{array}$ & $\begin{array}{l}\text { HCs } \\
\text { ETOH } \\
\text { CG } \\
\text { TOTAL }\end{array}$ & $\begin{array}{r}0.923 \\
0 \\
0.053 \\
0.976\end{array}$ & $\begin{array}{r}104,045 \\
0 \\
5,988 \\
110,033\end{array}$ & $\begin{array}{l}0.940 \\
0.000 \\
0.054 \\
0.894\end{array}$ & $\begin{array}{r}105,975 \\
0 \\
6,099 \\
112,075\end{array}$ & $\begin{array}{r}105,975 \\
0 \\
6,099 \\
112,075\end{array}$ & $\begin{array}{r}14,252 \\
0 \\
860 \\
15,112\end{array}$ & $\begin{array}{r}8,547 \\
0 \\
627 \\
8,174\end{array}$ & $\begin{array}{r}120,227 \\
0 \\
6,959 \\
127,186\end{array}$ & $\begin{array}{r}120,227 \\
0 \\
6.959 \\
127.186\end{array}$ & $\begin{array}{r}114,522 \\
0 \\
6,726 \\
121,248\end{array}$ & $\begin{array}{r}10.795 \\
0 \\
628 \\
11,423\end{array}$ \\
\hline \multirow{2}{*}{ CGINPADD II } & $\begin{array}{l}\text { HCs } \\
\text { MTBE } \\
\text { TOTAL }\end{array}$ & $\begin{array}{l}0.980 \\
0.020 \\
1.000\end{array}$ & $\begin{array}{r}110,446 \\
1 ., 870 \\
112,316\end{array}$ & $\begin{array}{l}0.978 \\
0.020 \\
0.898\end{array}$ & $\begin{array}{r}110,209 \\
1,866 \\
112,075\end{array}$ & $\begin{array}{r}110,209 \\
413 \\
110,622\end{array}$ & $\begin{array}{r}15,537 \\
530 \\
16,067\end{array}$ & $\begin{array}{r}11,330 \\
0 \\
11,330\end{array}$ & $\begin{array}{r}125,746 \\
2,396 \\
128,141\end{array}$ & $\begin{array}{r}125,746 \\
2,396 \\
128,141\end{array}$ & $\begin{array}{r}121,538 \\
413 \\
121,952\end{array}$ & $\begin{array}{r}11,356 \\
1189 \\
11.545\end{array}$ \\
\hline & & & & & & & & & & & . & \\
\hline
\end{tabular}

NEW ETOH = INCAEMENTALLY PRODUCED ETHANOL AS OPPOSED TO ETHANOL DIVERTED FROM EXISTING MARKETS

EXISTING ETOH = ETHANOL DIVERTED FROM EXISTING MARKETS 
TABLE H.3 Fuel Volume and Energy Content for RFG with 2.1 wt\% Oxygen: Ho Estimates

(Energy, Oil, and $\mathrm{CO}_{2}$-Equivalent Emissions for RFG Volumes That Contain the Same Energy as Summer RFG with MTBE at 2.1 wt\% Oxygen)

\begin{tabular}{|c|c|c|c|c|c|c|c|c|c|c|c|c|}
\hline FUEL TYPE & $\begin{array}{l}\text { COMPO- } \\
\text { NENIS }\end{array}$ & $\begin{array}{c}\text { INITIAL } \\
\text { VOLUME } \\
\text { GALLONS } \\
\end{array}$ & $\begin{array}{c}\text { ENERGY } \\
\text { CONTENT } \\
\text { OFINITIAL } \\
\text { VOLUME } \\
\text { BTU } \\
\end{array}$ & $\begin{array}{c}\text { REVISED VOL TO } \\
\text { DELIVER EQUAL } \\
\text { BTU AS SUMMER } \\
\text { RFG AT 2.1\% OXY } \\
\text { WI MTEE ONLY } \\
\text { GALLONS } \\
\end{array}$ & $\begin{array}{c}\text { REVISED } \\
\text { ENERGY } \\
\text { CONIENT } \\
\text { BTU } \\
\end{array}$ & $\begin{array}{c}\begin{array}{c}\text { OlL } \\
\text { CONTENT } \\
\text { (FEEDSTOCK) }\end{array} \\
\text { BIU } \\
\end{array}$ & $\begin{array}{c}\text { ENERGY } \\
\text { AEQUIRED } \\
\text { TO PRODUCE } \\
\text { AFG } \\
\text { BTU } \\
\end{array}$ & $\begin{array}{c}\text { OIL } \\
\text { REQUIRED } \\
\text { TOPRODUCE } \\
\text { RFG } \\
\text { BTU } \\
\end{array}$ & $\begin{array}{c}\text { TOTAL ENERGY } \\
\text { REQUIRED TO } \\
\text { DELIVER RFG } \\
\text { BTU } \\
\end{array}$ & $\begin{array}{c}\text { TOTAL } \\
\text { FOSSIL ENERGY } \\
\text { REQUIRED TO } \\
\text { DELIVER RFG } \\
\text { BTU } \\
\end{array}$ & $\begin{array}{c}\text { TOTALOIL } \\
\text { REQUIRED TO } \\
\text { DELIVER RFG } \\
\text { BTU } \\
\end{array}$ & $\begin{array}{c}\begin{array}{c}\text { CO2- } \\
\text { EQUIVALENT } \\
\text { EMISSIONS }\end{array} \\
G \\
\end{array}$ \\
\hline \multicolumn{13}{|c|}{$\begin{array}{l}\text { SUMMER FUELS ANALYSIS } \\
\text { AFG }\end{array}$} \\
\hline $\begin{array}{l}\text { WITH MTEE } \\
\text { AT } 2.1 \% \text { O2 } \\
\text { PFG }\end{array}$ & $\begin{array}{l}\text { HCs } \\
\text { MTBE } \\
\text { TOTAL }\end{array}$ & $\begin{array}{l}0.885 \\
0.116 \\
1.000\end{array}$ & $\begin{array}{r}101275 \\
10799 \\
112075\end{array}$ & $\begin{array}{l}0.885 \\
0.116 \\
1.000\end{array}$ & $\begin{array}{r}101275 \\
10799 \\
112075\end{array}$ & $\begin{array}{r}101275 \\
641 \\
101816\end{array}$ & $\begin{array}{r}16017 \\
3216 \\
19233\end{array}$ & $\begin{array}{r}8072 \\
0 \\
8072\end{array}$ & $\begin{array}{r}117293 \\
11015 \\
131308\end{array}$ & $\begin{array}{r}117293 \\
14015 \\
131308\end{array}$ & $\begin{array}{r}110347 \\
641 \\
110988\end{array}$ & $\begin{array}{r}10749 \\
1094 \\
11844\end{array}$ \\
\hline $\begin{array}{l}\text { WITH ETBE } \\
\text { AT } 2.1 \% 02 \\
\text { (NEW ETOH) } \\
\text { AFG }\end{array}$ & $\begin{array}{l}\text { HCs } \\
\text { ETBE } \\
\text { TOTAL }\end{array}$ & $\begin{array}{l}0.866 \\
0.134 \\
1.000\end{array}$ & $\begin{array}{r}99157 \\
12985 \\
112142\end{array}$ & $\begin{array}{l}0.865 \\
0.134 \\
0.899\end{array}$ & $\begin{array}{r}99098 \\
12977 \\
112075\end{array}$ & $\begin{array}{r}89098 \\
671 \\
89768\end{array}$ & $\begin{array}{r}15457 \\
7037 \\
22493\end{array}$ & $\begin{array}{r}8661 \\
702 \\
8362\end{array}$ & $\begin{array}{r}114554 \\
20014 \\
134568\end{array}$ & $\begin{array}{r}114554 \\
15338 \\
129892\end{array}$ & $\begin{array}{r}107758 \\
1372 \\
109131\end{array}$ & $\begin{array}{r}10479 \\
1518 \\
11997\end{array}$ \\
\hline $\begin{array}{l}\text { WITH ETBE } \\
\text { AT } 2.1 \% \text { O2 } \\
\text { (EXISTING ETOH) }\end{array}$ & $\begin{array}{l}\text { HCs } \\
\text { ETgE } \\
\text { - ETOH } \\
\text { CG } \\
\text { TOTAL }\end{array}$ & $\begin{array}{l}0.866 \\
0.134 \\
0.060 \\
0.041 \\
0.981\end{array}$ & $\begin{array}{r}89157 \\
12985 \\
4678 \\
4678 \\
112142\end{array}$ & $\begin{array}{l}0.865 \\
0.134 \\
0.060 \\
0.041 \\
0.880\end{array}$ & $\begin{array}{r}99098 \\
12977 \\
4675 \\
4675 \\
112075\end{array}$ & $\begin{array}{r}99098 \\
671 \\
234 \\
4675 \\
104210\end{array}$ & $\begin{array}{r}15457 \\
7037 \\
5035 \\
724 \\
18182\end{array}$ & $\begin{array}{r}8661 \\
702 \\
734 \\
550 \\
8178\end{array}$ & $\begin{array}{r}114554 \\
20014 \\
9711 \\
5399 \\
130256\end{array}$ & $\begin{array}{r}114554 \\
15338 \\
5035 \\
5398 \\
130256\end{array}$ & $\begin{array}{r}107758 \\
1372 \\
868 \\
5225 \\
113308\end{array}$ & $\begin{array}{r}10479 \\
1518 \\
686 \\
493 \\
11804\end{array}$ \\
\hline 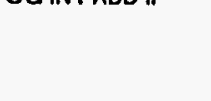 & $\begin{array}{l}\text { HCs } \\
\text { MTBE } \\
\text { TOTAL. }\end{array}$ & $\begin{array}{l}0.980 \\
0.020 \\
1.000\end{array}$ & $\begin{array}{r}112210 \\
1870 \\
114080\end{array}$ & $\begin{array}{l}0.963 \\
0.020 \\
0.882\end{array}$ & $\begin{array}{r}110237 \\
1837 \\
112075\end{array}$ & $\begin{array}{r}110237 \\
1032 \\
111269\end{array}$ & $\begin{array}{r}17069 \\
467 \\
17537\end{array}$ & $\begin{array}{r}12960 \\
0 \\
12960\end{array}$ & $\begin{array}{r}127306 \\
2305 \\
129611\end{array}$ & $\begin{array}{r}127306 \\
2305 \\
129611\end{array}$ & $\begin{array}{r}123197 \\
1032 \\
124228\end{array}$ & $\begin{array}{r}11634 \\
186 \\
11821\end{array}$ \\
\hline \multicolumn{13}{|c|}{$\begin{array}{l}\text { WINTER FUELS ANALYSIS } \\
\text { RFG }\end{array}$} \\
\hline $\begin{array}{l}\text { WTH MTBE } \\
\text { AT } 2.1 \% \text { O2 } \\
\text { AFG }\end{array}$ & $\begin{array}{l}\text { HCs } \\
\text { MTBE } \\
\text { TOTAL }\end{array}$ & $\begin{array}{l}0.885 \\
0.116 \\
1.000\end{array}$ & $\begin{array}{r}89683 \\
10799 \\
110482\end{array}$ & $\begin{array}{l}0.897 \\
0.117 \\
1.014\end{array}$ & $\begin{array}{r}101120 \\
10955 \\
112075\end{array}$ & $\begin{array}{r}101120 \\
0 \\
101120\end{array}$ & $\begin{array}{r}13481 \\
3318 \\
16799\end{array}$ & $\begin{array}{r}7884 \\
0 \\
7984\end{array}$ & $\begin{array}{r}114601 \\
14273 \\
128874\end{array}$ & $\begin{array}{r}114601 \\
14273 \\
128874\end{array}$ & $\begin{array}{r}109104 \\
0 \\
109104\end{array}$ & $\begin{array}{r}10279 \\
1110 \\
11389\end{array}$ \\
\hline $\begin{array}{l}\text { WTHHETHANOL } \\
\text { AT 2.1\% O2 } \\
\text { (NEWETOH) } \\
\text { RFG }\end{array}$ & $\begin{array}{l}\text { HCs } \\
\text { ETOH } \\
\text { TOTAL }\end{array}$ & $\begin{array}{l}0.940 \\
0.060 \\
1.000\end{array}$ & $\begin{array}{r}105938 \\
4678 \\
110616\end{array}$ & $\begin{array}{l}0.952 \\
0.061 \\
1.013\end{array}$ & $\begin{array}{r}107335 \\
4740 \\
112075\end{array}$ & $\begin{array}{r}107335 \\
237 \\
107572\end{array}$ & $\begin{array}{r}14435 \\
5105 \\
19540\end{array}$ & $\begin{array}{r}8656 \\
744 \\
9400\end{array}$ & $\begin{array}{r}121769 \\
9845 \\
131614\end{array}$ & $\begin{array}{r}121769 \\
5105 \\
126874\end{array}$ & $\begin{array}{r}115991 \\
981 \\
116972\end{array}$ & $\begin{array}{r}10933 \\
695 \\
11628\end{array}$ \\
\hline $\begin{array}{l}\text { WTHH ETHANOL } \\
\text { AT 2.1\% O2 } \\
\text { (EXISTING ETOH) }\end{array}$ & $\begin{array}{l}\text { HCs } \\
\text { ETOH } \\
\text { CG } \\
\text { TOTAL }\end{array}$ & $\begin{array}{r}0.940 \\
0 \\
0.042 \\
0.982\end{array}$ & $\begin{array}{r}105938 \\
0 \\
4678 \\
110616\end{array}$ & $\begin{array}{l}0.952 \\
0.000 \\
0.042 \\
0.984\end{array}$ & $\begin{array}{r}107335 \\
0 \\
4740 \\
112075\end{array}$ & $\begin{array}{r}107335 \\
0 \\
4740 \\
112075\end{array}$ & $\begin{array}{r}14435 \\
0 \\
668 \\
15103\end{array}$ & $\begin{array}{r}8656 \\
0 \\
487 \\
9144\end{array}$ & $\begin{array}{r}121769 \\
0 \\
5408 \\
127178\end{array}$ & $\begin{array}{r}121769 \\
0 \\
5408 \\
127178\end{array}$ & $\begin{array}{r}115891 \\
0 \\
5227 \\
121218\end{array}$ & $\begin{array}{r}10933 \\
0 \\
488 \\
11422\end{array}$ \\
\hline - & $\begin{array}{l}\text { HCs } \\
\text { MTBE } \\
\text { TOTAL }\end{array}$ & $\begin{array}{l}0.980 \\
0.020 \\
1.000\end{array}$ & $\begin{array}{r}110446 \\
1870 \\
112316\end{array}$ & $\begin{array}{l}0.978 \\
0.020 \\
0.898\end{array}$ & $\begin{array}{r}110209 \\
1866 \\
112075\end{array}$ & $\begin{array}{r}110209 \\
413 \\
110622\end{array}$ & $\begin{array}{r}15537 \\
530 \\
16067\end{array}$ & $\begin{array}{r}11330 \\
0 \\
11330\end{array}$ & $\begin{array}{r}125746 \\
2386 \\
128141\end{array}$ & $\begin{array}{r}125746 \\
2396 \\
128141\end{array}$ & $\begin{array}{r}121538 \\
413 \\
121852\end{array}$ & $\begin{array}{r}11356 \\
189 \\
11545\end{array}$ \\
\hline
\end{tabular}

NEW ETOH = INCREMENTALLLY PRODUCED ETHANOL AS OPPOSED TO ETHANOL OIVERTED FROM EXISTING MARKETS

EXISTING ETOH = ETHANOL DIVERTED FROM EXISTING MARKETS 
TABLE H.4 Fuel Volume and Energy Content for RFG with 2.7 wt\% Oxygen: Ho Estimates (Energy, Oil, and $\mathrm{CO}_{2}$-Equivalent Emissions for RFG Volumes That Contain the Same Energy as Summer RFG with MTBE at 2.1 wt\% Oxygen)

\begin{tabular}{|c|c|c|c|c|c|c|c|c|c|c|c|c|}
\hline FUEL TYPE & $\begin{array}{l}\text { COMPO- } \\
\text { NENTS }\end{array}$ & $\begin{array}{l}\text { INITIAL } \\
\text { VOLUME }\end{array}$ & $\begin{array}{r}\text { ENERGY } \\
\text { CONTENT } \\
\text { OF INITIAL. } \\
\text { VOLUME } \\
\end{array}$ & $\begin{array}{l}\text { REVISED VOL TO } \\
\text { DELIVER EQUAL } \\
\text { BTU AS SUMMER } \\
\text { RFG AT 2.1\% OXY } \\
\text { WI MTBE ONLY } \\
\end{array}$ & $\begin{array}{l}\text { AEVISED } \\
\text { ENERGY } \\
\text { CONTENT }\end{array}$ & $\begin{array}{r}\text { OLL } \\
\text { CONTENT } \\
\text { EEEDSTOCKL }\end{array}$ & $\begin{array}{r}\text { ENERGY } \\
\text { REQUIRED } \\
\text { TO PRODUCE } \\
\text { RFG } \\
\end{array}$ & $\begin{array}{r}\text { Oll } \\
\text { REQUIRED } \\
\text { TO PRODUCE } \\
\text { RFG } \\
\end{array}$ & $\begin{array}{r}\text { TOTAL ENERGY } \\
\text { REQUIRED TO } \\
\text { DELIVER RFG } \\
\end{array}$ & $\begin{array}{r}\text { TOTAL } \\
\text { FOSSIL ENERGY } \\
\text { REQUIRED TO } \\
\text { DELIVER RFG } \\
\end{array}$ & $\begin{array}{r}\text { TOTAL OIL } \\
\text { REQUIAED YO } \\
\text { DELIVER RFG } \\
\end{array}$ & $\begin{array}{r}\text { CO2. } \\
\text { EQUIVALENT } \\
\text { EMISSIONS } \\
\end{array}$ \\
\hline & & GALLONS & BTU & GALLONS & BIU & BTU & BTU & BTU & BTU & Bru & BTU & $\underline{G}$ \\
\hline $\begin{array}{l}\text { RFG } \\
\text { WITH MTBE } \\
\text { AT } 2.7 \% 02\end{array}$ & $\begin{array}{l}\text { HCs } \\
\text { MTBE } \\
\text { TOTAL }\end{array}$ & $\begin{array}{l}0.852 \\
0.149 \\
1.000\end{array}$ & $\begin{array}{r}95964 \\
13885 \\
109849\end{array}$ & $\begin{array}{l}0.869 \\
0.152 \\
1.020\end{array}$ & $\begin{array}{r}97908 \\
14166 \\
112075\end{array}$ & $\begin{array}{r}87908 \\
0 \\
97908\end{array}$ & $\begin{array}{r}13053 \\
4299 \\
17344\end{array}$ & $\begin{array}{r}7730 \\
0 \\
7730\end{array}$ & $\begin{array}{r}110961 \\
18457 \\
129418\end{array}$ & $\begin{array}{r}110961 \\
18457 \\
129418\end{array}$ & $\begin{array}{r}105639 \\
0 \\
105638\end{array}$ & $\begin{array}{r}9953 \\
1435 \\
11388\end{array}$ \\
\hline $\begin{array}{l}\text { RFG } \\
\text { WITH ETHANOL } \\
\text { AT } 2.7 \% \text { O2 } \\
\text { (NEWETOH) } \\
\text { RFG }\end{array}$ & $\begin{array}{l}\text { HCs } \\
\text { ETOH } \\
\text { TOTAL }\end{array}$ & $\begin{array}{l}0.923 \\
0.077 \\
1.000\end{array}$ & $\begin{array}{r}104045 \\
5988 \\
110033\end{array}$ & $\begin{array}{l}0.940 \\
0.078 \\
1.019\end{array}$ & $\begin{array}{r}105975 \\
6099 \\
112075\end{array}$ & $\begin{array}{r}105975 \\
305 \\
106280\end{array}$ & $\begin{array}{r}14252 \\
6569 \\
20821\end{array}$ & $\begin{array}{r}8547 \\
958 \\
8504\end{array}$ & $\begin{array}{r}120227 \\
12668 \\
132895\end{array}$ & $\begin{array}{r}120227 \\
6569 \\
126786\end{array}$ & $\begin{array}{r}114522 \\
1263 \\
115785\end{array}$ & $\begin{array}{r}10795 \\
895 \\
11690\end{array}$ \\
\hline $\begin{array}{l}\text { WTH ETHANOL } \\
\text { AT } 2.7 \% \text { O2 } \\
\text { (EXISTING ETOH) }\end{array}$ & $\begin{array}{l}\text { HCs } \\
\text { ETOH } \\
\text { CG } \\
\text { TOTAL }\end{array}$ & $\begin{array}{r}0.823 \\
0 \\
0.053 \\
0.976\end{array}$ & $\begin{array}{r}104045 \\
0 \\
5988 \\
110033\end{array}$ & $\begin{array}{l}0.940 \\
0.000 \\
0.054 \\
0.994\end{array}$ & $\begin{array}{r}105975 \\
0 \\
6099 \\
112075\end{array}$ & $\begin{array}{r}105975 \\
0 \\
6089 \\
112075\end{array}$ & $\begin{array}{r}14252 \\
0 \\
860 \\
15112\end{array}$ & $\begin{array}{r}8547 \\
0 \\
627 \\
8174\end{array}$ & $\begin{array}{r}120227 \\
0 \\
6958 \\
127186\end{array}$ & $\begin{array}{r}120227 \\
0 \\
6959 \\
127186\end{array}$ & $\begin{array}{r}114522 \\
0 \\
6726 \\
121248\end{array}$ & $\begin{array}{r}10795 \\
0 \\
628 \\
11423\end{array}$ \\
\hline & $\begin{array}{l}\text { HCs } \\
\text { MTBE } \\
\text { TOTAL }\end{array}$ & $\begin{array}{l}0.980 \\
0.020 \\
1.000\end{array}$ & $\begin{array}{r}110446 \\
1870 \\
112316\end{array}$ & $\begin{array}{l}0.978 \\
0.020 \\
0.998\end{array}$ & $\begin{array}{r}110209 \\
1866 \\
112075\end{array}$ & $\begin{array}{r}110209 \\
413 \\
110622\end{array}$ & $\begin{array}{r}15537 \\
530 \\
16067\end{array}$ & $\begin{array}{r}11330 \\
0 \\
11330\end{array}$ & $\begin{array}{r}125746 \\
2396 \\
128141\end{array}$ & $\begin{array}{r}125746 \\
2396 \\
128141\end{array}$ & $\begin{array}{r}121538 \\
413 \\
121852\end{array}$ & $\begin{array}{r}11356 \\
189 \\
11545\end{array}$ \\
\hline
\end{tabular}

NEW ETOH = INCREMENTALLY PRODUCED ETHANOL. AS OPPOSED TO ETHANOL DIVERTED FROM EXISTING MAFKETS

EXISTING ETOH - ETHANOL DIVERTED FROM EXISTING MARKETS 


\section{DISTRIBUTION FOR ANL/ESD-28}

Internal

ANL Technical Publications Service

R. Weeks

S. Juricic (5) M. Moniger

K. Stork (102)

\section{External}

U.S. Department of Energy Office of Scientific and Technical Information (12)

Manager, U.S. Department of Energy Chicago Field Office

ANL-E Libraries (2)

ANL-W Library 